Keywords: Statistical Process Control, MFT, Melter, PCCS

Retention Time: Permanent

\title{
SME ACCEPTABILITY DETERMINATION FOR DWPF PROCESS CONTROL (U)
}

Publication Date: August 30, 2002

Westinghouse Savannah River Company

Savannah River Technology Center Aiken, SC 29808

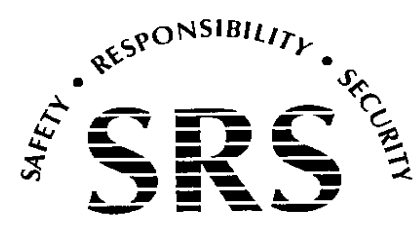


This document was prepared in conjunction with work accomplished under Contract No. DE-AC09-96SR18500 with the U. S. Department of Energy.

\section{DISCLAIMER}

This report was prepared as an account of work sponsored by an agency of the United States Government. Neither the United States Government nor any agency thereof, nor any of their employees, makes any warranty, express or implied, or assumes any legal liability or responsibility for the accuracy, completeness, or usefulness of any information, apparatus, product or process disclosed, or represents that its use would not infringe privately owned rights. Reference herein to any specific commercial product, process or service by trade name, trademark, manufacturer, or otherwise does not necessarily constitute or imply its endorsement, recommendation, or favoring by the United States Government or any agency thereof. The views and opinions of authors expressed herein do not necessarily state or reflect those of the United States Government or any agency thereof.

This report has been reproduced directly from the best available copy.

Available for sale to the public, in paper, from: U.S. Department of Commerce, National Technical Information Service, 5285 Port Royal Road, Springfield, VA 22161, phone: (800) 553-6847, fax: (703) 605-6900

email: orders@ntis.fedworld.gov

online ordering: http://www.ntis.gov/help/index.asp

Available electronically at http://www.osti.gov/bridge

Available for a processing fee to U.S. Department of Energy and its contractors, in paper, from: U.S. Department of Energy, Office of Scientific and Technical Information, P.O. Box 62, Oak Ridge, TN 37831-0062,

phone: (865)576-8401,

fax: (865)576-5728

email: $\underline{\text { reports@ adonis.osti.gov }}$ 


\section{SME ACCEPTABILITY DETERMINATION FOR DWPF PROCESS CONTROL (U)}

Originators and Developers: K. G. Brown and R. L. Postles

Revision 4 Editor: T. B. Edwards

August 30, 2002

Document Approvals

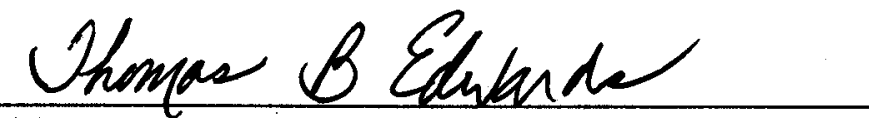

T. B. Edwards, Statistical Consulting Section Revision 4 Editor

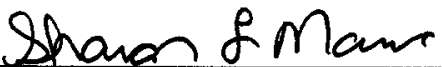

S. L. Marra, Immobilization Technology Section Manager

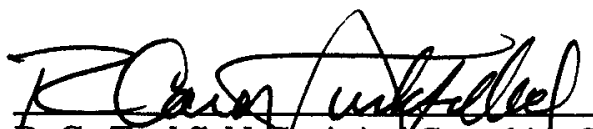

R. C. Tuckfield, Etatisticol Consulting Section Section Manager

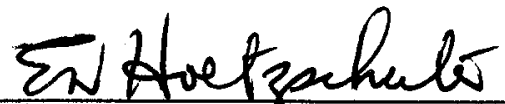

E. W. Holtzscheiter, Immobilization Technology Section Section Manager

Authorized Derivative Classifier
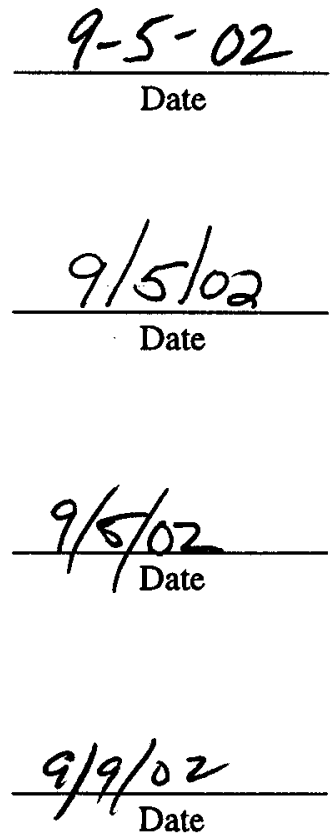
WSRC-TR-95-000364

Revision 4

This page intentionally left blank. 


\section{Preface}

This document has supported the technical basis for the Defense Waste Processing Facility (DWPF) of the Savannah River Site (SRS) since the DWPF began radioactive operation in 1996. The facility blends High Level Waste (HLW) with glass frit and vitrifies the resulting mix into a stable, borosilicate wasteform. While doing so, it must satisfy, with appropriate confidence, several product and process constraints. These include constraints on:

- the process melt (i.e., melt viscosity and liquidus temperature) to assure that the material is processable and

- the quality of the resulting wasteform (i.e., durability of the glass product).

DWPF personnel cannot wait until the melt or waste glass has been made to assess its acceptability, since by then no further changes to either are possible. Therefore, the acceptability decision is made on the upstream process, rather than on the downstream melt or glass product. That is, it is based on statistical process control rather than statistical quality control.

The decision whether a particular process slurry feed batch will produce a melt (and thus glass) that will satisfy the aforementioned constraints is necessarily based on sampling and measurement. These samples and measurements are uncertain because of random and systematic "errors" of various kinds and, the acceptability decision must be made in the face of these uncertainties. It is, accordingly, a statistical decision. The acceptability decision is described in this document, and a statistical system is developed to adjudge whether, after allowing for appropriate uncertainties, the relevant measurements and projections are sufficiently distant from the constraints to be acceptable. The statistical system is called the Product Composition Control System (PCCS) and, when implemented, it guides acceptability decisions during radioactive operations at the DWPF.

The glass and melt properties that must be controlled have been related to glass composition, which is, in turn, dictated by feed slurry composition. Accordingly, the PCCS strategy is to blend and then monitor the composition of the feed slurry in the Slurry Mix Evaporator (SME). The SME is both the first control point in the DWPF process wherein all necessary constituents are present and the last control point at which any change to them can be effected. The PCCS thus deals with monitoring the blended SME batch.

Uncertainties inhere to all DWPF operations. These uncertainties afflict all steps of, and all samples and measurements on, the process. Uncertainty afflicts the propertycomposition models. It afflicts the collection of slurry samples, the preparation of these samples for measurement, and the measurements themselves. 
WSRC-TR-95-000364

Revision 4

The aggregate of all this uncertainty motivates the use of the PCCS. The PCCS enables rational decisions concerning acceptability in the face of this aggregated uncertainty by accounting for it in a methodical, logical, and quantitative way.

Thus, the main focus of PCCS is to monitor an extant SME batch to see whether is it acceptable. The purpose of this report is to provide the technical basis for PCCS. 


\section{INTRODUCTION}

The Defense Waste Processing Facility (DWPF) at the Savannah River Site (SRS) in Aiken, South Carolina, began immobilizing high-level radioactive waste (HLW) in borosilicate glass in 1996. For its HLW immobilization to be successful, the facility must consistently obey several product and process constraints including those related to melt viscosity and liquidus temperature (the processability of the material being vitrified) and to glass durability (the quality of the resulting wasteform product). The process and product properties are assessed through models that relate each of the properties to the chemical composition of the glass, which is determined from measurements of in-process samples taken on each process batch. A set of waste solubility constraints on the resulting glass product also must be satisfied.

The system used by the DWPF to assist in the assessment of the performance of a process batch against the applicable constraints is called the Product Composition Control System (PCCS). The PCCS guides the acceptability decision for each DWPF process batch. This report, in its earlier versions, has served as the technical basis for that system since the beginning of radioactive operations. The report is being revised to compile several modifications to the acceptability decision at the DWPF that have been introduced since revision 3 was issued on February 21, 1996. The major modification is the implementation of the new liquidus temperature model. Other modifications include the revised upper limit on viscosity and options for satisfying the low frit and homogeneity constraints. This revision re-establishes the report as the technical basis for PCCS.

The remainder of this report is organized as follows. In the next section, an overview of the strategy supporting the acceptability decisions is provided. Section 3 specifies the original constraints imposed on the DWPF operations, identifies the associated categories of uncertainties that must be accounted for, and establishes the corresponding levels of confidence. In Section 4, recently developed alternatives for satisfying the DWPF's original constraints are outlined and their impact on the control strategy is discussed. Section 5 and its sub-sections provide a detailed, systematic discussion of each of the constraints including property model and measurement uncertainties. In Section 6, issues associated with redox (reduction/oxidation) are discussed. Section 7 provides a sample calculation to illustrate the use of the DWPF Product Composition Control System. The appendices provide additional details and discussion supporting the PCCS calculations.

\section{Overview of The Control Strategy}

In the DWPF, radioactive sludge is blended with ground glass (frit) in the Slurry Mix Evaporator (SME) to produce melter feed slurry. From here, the material then passes to the Melter Feed Tank (MFT), which continuously feeds the melter. The melter vitrifies the feed slurry into a molten glass wasteform, which is poured into stainless steel canisters for cooling and ultimate storage.

DWPF personnel cannot wait until the melt or waste glass has been made to assess its acceptability, since by then no further changes to either are possible. Therefore, the acceptability decision is made on the upstream process, rather than on the downstream 
melt or glass product. That is, it is based on statistical process control rather than statistical quality control, and the acceptability decision is made at the SME. The SME is uniquely positioned in the process - it is both the first control point in the process wherein all necessary constituents are present and the last control point at which any change to them can be effected. Thus, the control strategy involves monitoring the blended SME batch.

The monitoring of the SME is accomplished by sampling its contents. For each SME batch, a set of $(n \geq 4)$ samples is taken to initiate an acceptability decision. Each of these samples is vitrified and the chemical compositions of the resulting $\mathrm{n}$ glasses are measured. The average of the measured chemical compositions for a minimum of 4 samples is determined (see Appendix A for a description of the sample measurements), and this average composition serves as the basis for the acceptability decision for the SME batch.

However, the average chemical composition, while necessary, is not sufficient in and of itself, to complete the assessment of the performance of the SME contents against the constraints. Some of the constraints involve properties (either process or product quality) such as viscosity, liquidus temperature, and durability. These properties cannot be measured in situ, and thus, they must be predicted from models that relate these properties to glass composition. Not only must the model predictions satisfy their corresponding property constraints but also the constraints must be appropriately met after the applicable modeling uncertainties are introduced into the acceptability decision.

For the constraints involving property-composition models and for most of the other constraints that directly involve composition, the uncertainties associated with the SME samples must also be accounted for as part of the acceptability decision. The uncertainties, labeled measurement uncertainties in this report, include those related to the collection of the slurry samples in the SME, the preparation of these samples for measurement, and the measurements themselves.

A glass composition representing the "average" content of a SME batch is deemed to be within the acceptable operating window for the DWPF if all of the applicable constraints are satisfied, at appropriate confidence levels, after the all related property modeling and measurement uncertainties are accounted for. Conceptually, there is a layered approach to the acceptability decision. At the first step, the question is, does the average chemical composition representing the SME contents directly or through model predictions satisfy the constraints? If the answer is yes, the composition is said to be within the Expected Property Acceptable Region (EPAR). However, the EPAR does not account for uncertainties in the predicting models. If, after the property model uncertainties are accounted for (to be discussed later), the chemical composition still meets the constraints, then the composition is said to be within the Property Acceptable Region (PAR). And, finally, if, after measurement uncertainties are accounted for (to be discussed later), the chemical composition still meets the constraints, then the composition is said to be within the Measurement Acceptable Region (MAR). A composition that is within the MAR for 
each of the applicable constraints is said to be within the acceptable operating window of the DWPF.

Some additional comments regarding the control strategy are warranted. As mentioned earlier, some of the constraints are directly related to composition and do not involve model predictions. For these constraints there would be fewer layers in the above description that would be applicable. Specifically, the PAR limits would be the same as the EPAR limits for such constraints since there is no property model uncertainty. In a similar fashion, if there is no need to apply property modeling or measurement uncertainties for a given constraint (which is true for a pair of constraints related to the reliability of the chemical composition measurement themselves), then the EPAR limit equals the PAR limit equals the MAR limit for that constraint. Finally, the DWPF control strategy has evolved by the development of alternatives for satisfying some of the constraints as well a new property-composition model for liquidus temperature (these are discussed later).

\section{ORIGinal Constraints for The DWPF}

The original (at radioactive startup in 1996) constraints applicable to DWPF acceptability decisions are provided in Table 1, which provides the name of the constraint, the general form of the constraint, the type of constraint (i.e., what is the intended focus of the constraint), and the applicable uncertainties for the constraint. Note that no uncertainty is applied to the first constraint of Table 1, the conservation or "sum of oxides" constraint. The specification was defined by the principal investigator of [1] to assure that the laboratory was under control. That is, this constraint is used as a check on the reliability of the chemical composition measurements themselves. It is a bound on laboratory analyses based upon tolerable errors when attempting to predict durability from glass composition. As a result, no additional uncertainty need be incorporated when applying this constraint to the DWPF control strategy. 
Table 1. Original Constraints Applicable to DWPF Process and Product Control

\begin{tabular}{|c|c|c|c|}
\hline Name & Constraint & Type & $\begin{array}{c}\text { Applicable } \\
\text { Uncertainties }\end{array}$ \\
\hline Conservation & $95 \% \leq \Sigma$ (Major Oxides in wt $\%$ ) $\leq 105 \%$ & $\begin{array}{l}\text { Laboratory } \\
\text { Specification }\end{array}$ & None \\
\hline Durability & $\begin{array}{l}\mathrm{B}, \mathrm{Li} \text {, and } \mathrm{Na} \text { Leach } \leq \mathrm{EA} \text { Leach } \\
\text { based upon Product Consistency Test }(\mathrm{PCT})\end{array}$ & $\begin{array}{l}\text { Product } \\
\text { Acceptability }\end{array}$ & $\begin{array}{l}\text { Property and } \\
\text { Measurement }\end{array}$ \\
\hline Alumina & $\mathrm{g} \mathrm{Al}_{2} \mathrm{O}_{3} / 100 \mathrm{~g}$ glass $\geq 3.0$ & $\begin{array}{l}\text { Product } \\
\text { Acceptability }\end{array}$ & Measurement \\
\hline Homogeneity & 1.6035 sludge +5.6478 frit $>216.8092$ & $\begin{array}{l}\text { Product } \\
\text { Acceptability }\end{array}$ & Measurement \\
\hline Frit Loading & $70 \% \leq \Sigma($ Frit Oxides in wt $\%) \leq 85 \%$ & $\begin{array}{l}\text { Product } \\
\text { Acceptability }\end{array}$ & Measurement \\
\hline $\begin{array}{l}\text { Liquidus } \\
\text { Temperature }\end{array}$ & Liquidus Temperature $\left(\mathrm{T}_{\mathrm{L}}\right) \leq 1050^{\circ} \mathrm{C}$ & Processability & $\begin{array}{l}\text { Property and } \\
\text { Measurement }\end{array}$ \\
\hline $\begin{array}{l}\text { Melt Viscosity } \\
\text { at } 1150^{\circ} \mathrm{C}\end{array}$ & $20 \leq$ Viscosity $(\eta) \leq 100$ poise $(P)$ & Processability & $\begin{array}{l}\text { Property and } \\
\text { Measurement }\end{array}$ \\
\hline $\mathrm{TiO}_{2}$ & $\mathrm{~g} \mathrm{TiO}_{2} / 100 \mathrm{~g}$ glass $\leq 1.0$ & Waste Solubility & Measurement \\
\hline $\mathrm{NaCl}$ & $\mathrm{g} \mathrm{NaCl} / 100 \mathrm{~g}$ glass $\leq 1.0$ & Waste Solubility & Measurement \\
\hline $\mathrm{NaF}$ & $\mathrm{g} \mathrm{NaF} / 100 \mathrm{~g}$ glass $\leq 1.0$ & Waste Solubility & Measurement \\
\hline $\mathrm{Cr}_{2} \mathrm{O}_{3}$ & $\mathrm{~g} \mathrm{Cr}_{2} \mathrm{O}_{3} / 100 \mathrm{~g}$ glass $\leq 0.3$ & Waste Solubility & Measurement \\
\hline $\begin{array}{l}\mathrm{SO}_{4} \text { or } \\
\mathrm{Na}_{2} \mathrm{SO}_{4}\end{array}$ & $\begin{array}{l}\mathrm{g} \mathrm{SO}_{4} / 100 \mathrm{~g} \text { glass } \leq 0.40 \\
\mathrm{~g} \mathrm{Na}_{2} \mathrm{SO}_{4} / 100 \mathrm{~g} \text { glass } \leq 0.59\end{array}$ & Waste Solubility & Measurement \\
\hline $\mathrm{Cu}$ & $\mathrm{g} \mathrm{Cu} / 100 \mathrm{~g}$ glass $\leq 0.5$ & Waste Solubility & Measurement \\
\hline $\begin{array}{l}\mathrm{PO}_{4} \text { or } \\
\mathrm{P}_{2} \mathrm{O}_{5}\end{array}$ & $\begin{array}{l}\mathrm{g} \mathrm{PO}_{4} / 100 \mathrm{~g} \text { glass } \leq 3.0 \\
\mathrm{~g} \mathrm{P}_{2} \mathrm{O}_{5} / 100 \mathrm{~g} \text { glass } \leq 2.25\end{array}$ & Waste Solubility & Measurement \\
\hline
\end{tabular}

Glass produced in the DWPF must satisfy the constraints listed in Table 1 at the appropriate confidence levels. The confidence levels for the constraints associated with product acceptability or quality are discussed first. As detailed in the Waste Acceptance Product Specifications (or WAPS) [2], the normalized boron, lithium, and sodium releases for DWPF glasses must be better than the corresponding releases for the Environmental Assessment (EA) glass based upon the Product Consistency Test (PCT) [3] leach test. DWPF has chosen the option of showing that the PCT releases are at least "two sigma" better than the EA glass. This implies that these releases must be controlled to at least the $95 \%$ confidence level. Since the releases are predicted from durabilitycomposition models, the property uncertainties associated with the models are determined to a 95\% confidence in identifying the PARs and the measurement uncertainties associated with the measured composition are determined to a $95 \%$ confidence in identifying the MAR. The other constraints identified in Table 1 as being related to product acceptability do not involve property-composition models and as such only require that appropriate measurement uncertainty be applied. Once again, measurement uncertainties are applied at the $95 \%$ confidence level for these constraints. 
For the sake of consistency, the uncertainties (both property and measurement) of all other constraints (those associated with processability and waste solubilities) are controlled to the same confidence level (i.e., 95\%) in the discussion that follows. However, it is possible to adjust the confidence levels at which the other constraints are controlled at management's discretion since they are non-waste-affecting (i.e., they are not associated with product acceptability).

\section{Satisfying Constraints}

As discussed earlier, a measured composition representative of a SME process batch is adjudged to be acceptable if it falls within the MAR (Measurement Acceptance Region) for all of the applicable constraints provided in Table 1 (i.e., note that for the "sum of oxides" constraints, 95\% $\leq \Sigma$ (Major Oxides in wt $\%$ ) $\leq 105 \%$, these limits are both the PAR and MAR limits). As DWPF's radioactive processing progressed and associated studies at the Savannah River Technology Center (SRTC) were completed, knowledge and experience were gained that offered solutions to problems that arose during the operation of that facility. The impact of these efforts on satisfying the constraints of Table 1 are discussed in this section.

As part of the glass variability study conducted by SRTC to support the processing of Macrobatch 2 (MB2) at the DWPF, a pair of options [4] was identified for satisfying the homogeneity MAR for a SME batch. The homogeneity constraint is applied to the measured composition to assure that the glass is not likely to be phase separated (i.e., that the glass will be homogeneous). The constraint is part of the set associated with product acceptability, and it was developed [5] from the best information available before the beginning of radioactive operation. During the MB2 variability study, it was determined that this constraint would severely, and unnecessarily, limit the acceptable operating window for processing this material. Based upon the results of that study, applying measurement uncertainty to the homogeneity constraint for MB2 was seen as overly conservative. It was determined from a preponderance of data [4] that as long as the $\mathrm{Al}_{2} \mathrm{O}_{3}$ concentration was greater than $4 \mathrm{wt} \%$ in the glass (or $\mathrm{Al}_{2} \mathrm{O}_{3} \geq 3.0 \mathrm{wt} \%$ and the sum of alkali, defined as $\mathrm{Cs}_{2} \mathrm{O}+\mathrm{K}_{2} \mathrm{O}+\mathrm{Li}_{2} \mathrm{O}+\mathrm{Na}_{2} \mathrm{O}$, in the glass less than or equal to $19.3 \mathrm{wt} \%$ ), the measurement acceptance requirement for the homogeneity constraint could be relaxed for MB2.

The implementation of either of the two options would require, however, application of the appropriate measurement uncertainties (e.g., the $\mathrm{Al}_{2} \mathrm{O}_{3}$ content in the glass would have to be greater than $4.0 \mathrm{wt} \%$ plus measurement uncertainty). Also, note that this first option requires monitoring of the alkali content in the SME samples and thus introducing a new constraint:

$$
\mathrm{Cs}_{2} \mathrm{O}+\mathrm{K}_{2} \mathrm{O}+\mathrm{Li}_{2} \mathrm{O}+\mathrm{Na}_{2} \mathrm{O} \leq 19.3 \mathrm{wt} \%
$$




\section{Revision 4}

SRTC also conducted an evaluation of the lower limit of the frit loading constraint [6] and concluded that this constraint could be eliminated as long as the $\mathrm{Al}_{2} \mathrm{O}_{3}$ concentration in the glass was greater than $4.43 \mathrm{wt} \%$ plus measurement uncertainty.

A re-evaluation of the high viscosity constraint conducted by SRTC [7] during the processing of Macrobatch 2 (MB 2) led to the expansion of the upper limit to 110 poise for this constraint.

Finally, the solubility constraint associated with the $\mathrm{P}_{2} \mathrm{O}_{5}$ in the glass was removed from the scope of the PCCS system for this revision of the report [8]. This constraint is to be handled administratively by the DWPF.

Table 2 summarizes the impact of all of the studies on the alternatives for satisfying the constraints that are applicable to DWPF process and product control. Note that the $\mathrm{P}_{2} \mathrm{O}_{5}$ constraint has been shaded in Table 2 to indicate that this constraint is no longer in the scope of PCCS and that it will not discussed further in this report. 
Table 2. Satisfying Constraints Applicable to DWPF Process and Product Control

\begin{tabular}{|c|c|c|}
\hline Name & Constraint at EPAR Limit & Comments \\
\hline $\begin{array}{l}\text { Low } \\
\text { Conservation }\end{array}$ & $95 \% \leq \Sigma$ (Major Oxides in wt $\%$ ) & $\begin{array}{l}\text { No uncertainties need be applied to this constraint. Thus, the } \\
\text { EPAR limit }=\text { PAR limit }=\text { MAR limit }=95 \% \text { for this constraint. }\end{array}$ \\
\hline $\begin{array}{l}\text { High } \\
\text { Conservation }\end{array}$ & $\Sigma($ Major Oxides in wt $\%) \leq 105 \%$ & $\begin{array}{l}\text { No uncertainties need be applied to this constraint. Thus, the } \\
\text { EPAR limit = PAR limit = MAR limit }=105 \% \text { for this constraint. }\end{array}$ \\
\hline Durability & $\begin{array}{l}\mathrm{B}, \mathrm{Li} \text {, and } \mathrm{Na} \text { Leach } \leq \mathrm{EA} \text { Leach based } \\
\text { upon Product Consistency Test }(\mathrm{PCT})\end{array}$ & $\begin{array}{l}\text { The EPAR limits and the active PAR and MAR uncertainties (at } \\
95 \% \text { confidence) for these constraints are discussed below. } \\
\text { Compositions must satisfy the MAR for each of these constraints } \\
\text { with } 95 \% \text { confidence. }\end{array}$ \\
\hline Alumina & $\mathrm{g} \mathrm{Al}_{2} \mathrm{O}_{3} / 100 \mathrm{~g}$ glass $\geq 3.0$ & $\begin{array}{l}\text { Measurement uncertainty (MU) must be applied (at } 95 \% \\
\text { confidence) for this constraint; i.e., } \mathrm{Al}_{2} \mathrm{O}_{3} \geq 3.0 \mathrm{wt} \%+\mathrm{MU} \text {. }\end{array}$ \\
\hline Homogeneity & $\begin{array}{l}1.6035 \text { sludge }+5.6478 \text { frit }>216.8092 \\
\text { with sludge and frit being fully defined } \\
\text { later in the report. }\end{array}$ & $\begin{array}{l}\text { Since no property model uncertainty is to be applied, the EPAR } \\
\text { limit = PAR limit = } 216.8092 \text {. The SME composition must satisfy } \\
\text { the homogeneity PAR limit (i.e., the } 216.8092 \text { value for this } \\
\text { constraint); however options exist for satisfying the homogeneity } \\
\text { MAR to include [4], at a } 95 \% \text { confidence level: } \\
\mathrm{Al}_{2} \mathrm{O}_{3} \geq 3.0 \mathrm{wt} \%+\mathrm{MU} \text { and } \Sigma \text { alkali } \leq 19.3 \mathrm{wt} \% \text { - MU } \\
\text { or } \\
\mathrm{Al}_{2} \mathrm{O}_{3} \geq 4.0 \mathrm{wt} \%+\mathrm{MU}\end{array}$ \\
\hline $\begin{array}{l}\text { Low Frit } \\
\text { Loading }\end{array}$ & $70 \% \leq \Sigma($ Frit Oxides in wt $\%)$ & $\begin{array}{l}\text { Since no property model uncertainty is to be applied, the EPAR } \\
\text { limit = PAR limit }=70 \% \text {. However, an option exists that allows } \\
\text { for eliminating this constraint [6]. It may be omitted from } \\
\text { consideration if } \\
\qquad \mathrm{Al}_{2} \mathrm{O}_{3} \geq 4.43 \mathrm{wt} \%+\mathrm{MU} \text { at a } 95 \% \text { confidence level; otherwise } \\
\qquad \text { (Frit Oxides) } \geq 70 \%+\mathrm{MU} \text { at a } 95 \% \text { confidence level. }\end{array}$ \\
\hline $\begin{array}{l}\text { High Frit } \\
\text { Loading }\end{array}$ & $\Sigma($ Frit Oxides in wt $\%) \leq 85 \%$ & $\begin{array}{l}\text { Measurement uncertainty must be applied (at a 95\% confidence } \\
\text { level) for this constraint; i.e., } \Sigma \text { (Frit Oxides) } \leq 85 \% \text { - MU }\end{array}$ \\
\hline $\begin{array}{l}\text { Liquidus } \\
\text { Temperature }\end{array}$ & Liquidus Temperature $\left(\mathrm{T}_{\mathrm{L}}\right) \leq 1050^{\circ} \mathrm{C}$ & $\begin{array}{l}\text { There are active PAR and MAR uncertainties for this constraint } \\
\text { that must be accounted for (these are discussed below). A } \\
\text { composition must satisfy the MAR for this constraint (typically, } \\
\text { with } 95 \% \text { confidence). }\end{array}$ \\
\hline $\begin{array}{l}\text { Low } \\
\text { Viscosity }\end{array}$ & 20 poise $(P) \leq$ Viscosity $(\eta)$ & $\begin{array}{l}\text { There are active PAR and MAR uncertainties for this constraint } \\
\text { that must be accounted for (these are discussed below). A } \\
\text { composition must satisfy the MAR for this constraint with } 95 \% \\
\text { confidence. }\end{array}$ \\
\hline $\begin{array}{l}\text { High } \\
\text { Viscosity }\end{array}$ & Viscosity $(\eta) \leq 110$ poise $(P)$ & $\begin{array}{l}\text { There are active PAR and MAR uncertainties for this constraint } \\
\text { that must be accounted for (these are discussed below). A } \\
\text { compositions must satisfy the MAR for this constraints with } 95 \% \\
\text { confidence. }\end{array}$ \\
\hline $\mathrm{TiO}_{2}$ & $\mathrm{~g} \mathrm{TiO}_{2} / 100 \mathrm{~g}$ glass $\leq 1.0$ & $\begin{array}{l}\text { Measurement uncertainty must be applied (typically, at a } 95 \% \\
\text { confidence level) for this constraint; i.e., } \mathrm{TiO}_{2} \leq 1.0 \text { - MU }\end{array}$ \\
\hline $\mathrm{NaCl}$ & $\mathrm{g} \mathrm{NaCl} / 100 \mathrm{~g}$ glass $\leq 1.0$ & $\begin{array}{l}\text { Measurement uncertainty must be applied (typically, at a 95\% } \\
\text { confidence level) for this constraint; i.e., } \mathrm{NaCl} \leq 1.0 \text { - MU }\end{array}$ \\
\hline $\mathrm{NaF}$ & $\mathrm{g} \mathrm{NaF} / 100 \mathrm{~g}$ glass $\leq 1.0$ & $\begin{array}{l}\text { Measurement uncertainty must be applied (typically, at a } 95 \% \\
\text { confidence level) for this constraint; i.e., } \mathrm{NaF} \leq 1.0-\mathrm{MU}\end{array}$ \\
\hline $\mathrm{Cr}_{2} \mathrm{O}_{3}$ & $\mathrm{~g} \mathrm{Cr}_{2} \mathrm{O}_{3} / 100 \mathrm{~g}$ glass $\leq 0.3$ & $\begin{array}{l}\text { Measurement uncertainty must be applied (typically, at a 95\% } \\
\text { confidence level) for this constraint; i.e., } \mathrm{Cr}_{2} \mathrm{O}_{3} \leq 0.3 \text { - MU }\end{array}$ \\
\hline $\begin{array}{l}\mathrm{SO}_{4} \text { or } \\
\mathrm{Na}_{2} \mathrm{SO}_{4} \\
\end{array}$ & $\begin{array}{l}\mathrm{g} \mathrm{SO}_{4} / 100 \mathrm{~g} \text { glass } \leq 0.40 \\
\mathrm{~g} \mathrm{Na}_{2} \mathrm{SO}_{4} / 100 \mathrm{~g} \text { glass } \leq 0.59\end{array}$ & $\begin{array}{l}\text { Measurement uncertainty must be applied (typically, at a 95\% } \\
\text { confidence level) for this constraint; i.e., } \mathrm{SO}_{4} \leq 0.40 \text { - MU }\end{array}$ \\
\hline $\mathrm{Cu}$ & $\mathrm{g} \mathrm{Cu} / 100 \mathrm{~g}$ glass $\leq 0.5$ & $\begin{array}{l}\text { Measurement uncertainty must be applied (typically, at a } 95 \% \\
\text { confidence level) for this constraint; i.e., } \mathrm{Cu} \leq 0.5 \text { - MU }\end{array}$ \\
\hline $\begin{array}{l}\mathrm{PO}_{4} \text { or } \\
\mathrm{P}_{2} \mathrm{O}_{5}\end{array}$ & $\begin{array}{l}\mathrm{g} \mathrm{PO}_{4} / 100 \mathrm{~g} \text { glass } \leq 3.0 \\
\mathrm{~g} \mathrm{P}_{2} \mathrm{O}_{5} / 100 \mathrm{~g} \text { glass } \leq 2.25\end{array}$ & $\begin{array}{l}\text { One of the changes introduced by this report revision was the } \\
\text { removal of the assessment of this constraint from the scope of the } \\
\text { PCCS control system. }\end{array}$ \\
\hline
\end{tabular}




\section{CONSTRAINTS AND UNCERTAINTIES}

In the sub-sections that follow, the constraints listed in Table 2 are discussed. Included in the discussion are the details of the uncertainties (both property and measurement, where appropriate) associated with meeting or satisfying each constraint at the desired confidence level. In general, the property model uncertainty must be computed for each constraint that involves a property-composition model. The computation depends on information generated during the fitting of the particular model and this information is presented as part of the discussions for the sake of completeness. How this information is used in the computation of the property model uncertainty depends on the type of statistical interval selected to support the computation. Different types of statistical intervals are used depending on the situation. These issues are discussed in the subsections that follow.

The method for handling measurement uncertainty for each of the constraints is also discussed in the subsections that follow. Background information supporting these methods is presented as part of the discussion in Appendices A and B. Also, in Appendix A, the complete set of chemical components used in PCCS is established as well as a single unit of measurement for handling the concentrations of these components. That unit of measure is molar oxide, and the set of "average" molar oxide concentrations computed from a SME batch is represented by the row vector $\underline{z}$ (or $\underline{z}_{n}$ to indicate that the average is based on $\mathrm{n}$ samples).

To further simplify the assessment of the average SME composition against the acceptability constraints, the constraints will be transformed (to the extent possible) to an inequality of the form:

\section{Equation (1).}

$$
\underline{\mathrm{z}}^{\mathrm{T}}-\beta \geq 0
$$

where $\underline{a}$ is a row vector of constants appropriate for the given constraint, $\beta$ is the appropriate constraint offset (i.e., the remaining, non-composition-based terms of the constraint inequality) for the given constraint, and $\underline{a}^{T}$ indicates the transpose of the $\underline{a}$ vector.

\subsection{Conservation ("Sum OF OXIDES") CONSTRaints}

No uncertainties need to be applied to the conservation constraints. The specification for this pair of constraints was defined by the principal investigator of [3] to assure that the analytical laboratory was under control. That is, the constraints are used as a check on the reliability of the chemical composition measurements themselves. They provide a bound on laboratory analyses based upon tolerable errors when attempting to predict durability from glass composition. As a result, no additional uncertainty need be incorporated when applying this pair of constraints to the DWPF control strategy. Thus, 
if the $95 \%$ and $105 \%$ limits are considered the EPAR limits, then the EPAR limits equal the PAR limits, which equal the MAR limits for these constraints. Using the molar oxide notation to represent these constraints yields:

\section{Low Sum of Oxides Constraint:}

$$
\begin{aligned}
& \mathrm{z}_{\mathrm{Al}_{2} \mathrm{O}_{3}} \cdot \mathrm{M}_{\mathrm{Al}_{2} \mathrm{O}_{3}}+\mathrm{z}_{\mathrm{B}_{2} \mathrm{O}_{3}} \cdot \mathrm{M}_{\mathrm{B}_{2} \mathrm{O}_{3}}+\mathrm{z}_{\mathrm{BaO}} \cdot \mathrm{M}_{\mathrm{BaO}}+\mathrm{z}_{\mathrm{CaO}} \cdot \mathrm{M}_{\mathrm{CaO}}+\mathrm{z}_{\mathrm{Ce}_{2} \mathrm{O}_{3}} \cdot \mathrm{M}_{\mathrm{Ce}_{2} \mathrm{O}_{3}}+\mathrm{z}_{\mathrm{Cr}_{2} \mathrm{O}_{3}} \cdot \mathrm{M}_{\mathrm{Cr}_{2} \mathrm{O}_{3}} \\
& +\mathrm{z}_{\mathrm{Cs}_{2} \mathrm{O}} \cdot \mathrm{M}_{\mathrm{Cs}_{2} \mathrm{O}}+\mathrm{z}_{\mathrm{CuO}} \cdot \mathrm{M}_{\mathrm{CuO}}+\mathrm{z}_{\mathrm{Fe}_{2} \mathrm{O}_{3}} \cdot \mathrm{M}_{\mathrm{Fe}_{2} \mathrm{O}_{3}}+\mathrm{z}_{\mathrm{K}_{2} \mathrm{O}} \cdot \mathrm{M}_{\mathrm{K}_{2} \mathrm{O}}+\mathrm{z}_{\mathrm{La}_{2} \mathrm{O}_{3}} \cdot \mathrm{M}_{\mathrm{La}_{2} \mathrm{O}_{3}}+\mathrm{z}_{\mathrm{Li}_{2} \mathrm{O}} \cdot \mathrm{M}_{\mathrm{Li}_{2} \mathrm{O}} \\
& +\mathrm{z}_{\mathrm{MgO}} \cdot \mathrm{M}_{\mathrm{MgO}}+\mathrm{z}_{\mathrm{MnO}} \cdot \mathrm{M}_{\mathrm{MnO}}+\mathrm{z}_{\mathrm{MoO}_{3}} \cdot \mathrm{M}_{\mathrm{MoO}_{3}}+\mathrm{z}_{\mathrm{Na}_{2} \mathrm{O}} \cdot \mathrm{M}_{\mathrm{Na}_{2} \mathrm{O}}+\mathrm{z}_{\mathrm{Ne}_{2} \mathrm{O}_{3}} \cdot \mathrm{M}_{\mathrm{Ne}_{2} \mathrm{O}_{3}}+\mathrm{z}_{\mathrm{NiO}} \cdot \mathrm{M}_{\mathrm{NiO}} \\
& +\mathrm{z}_{\mathrm{P}_{2} \mathrm{O}_{5}} \cdot \mathrm{M}_{\mathrm{P}_{2} \mathrm{O}_{5}}+\mathrm{z}_{\mathrm{PbO}} \cdot \mathrm{M}_{\mathrm{PbO}}+\mathrm{z}_{\mathrm{SiO}_{2}} \cdot \mathrm{M}_{\mathrm{SiO}_{2}}+\mathrm{z}_{\mathrm{ThO}_{2}} \cdot \mathrm{M}_{\mathrm{ThO}_{2}}+\mathrm{z}_{\mathrm{TiO}_{2}} \cdot \mathrm{M}_{\mathrm{TiO}_{2}}+\mathrm{z}_{\mathrm{U}_{3} \mathrm{O}_{8}} \cdot \mathrm{M}_{\mathrm{U}_{3} \mathrm{O}_{8}} \\
& +\mathrm{z}_{\mathrm{Y}_{2} \mathrm{O}_{3}} \cdot \mathrm{M}_{\mathrm{Y}_{2} \mathrm{O}_{3}}+\mathrm{z}_{\mathrm{ZnO}} \cdot \mathrm{M}_{\mathrm{ZnO}}+\mathrm{z}_{\mathrm{ZrO}_{2}} \cdot \mathrm{M}_{\mathrm{ZrO}_{2}}-95 \geq 0
\end{aligned}
$$

$\underline{\text { High Sum of Oxides Constraint: }}$

$$
\begin{aligned}
& \mathrm{z}_{\mathrm{Al}_{2} \mathrm{O}_{3}} \cdot\left(-\mathrm{M}_{\mathrm{Al}_{2} \mathrm{O}_{3}}\right)+\mathrm{z}_{\mathrm{B}_{2} \mathrm{O}_{3}} \cdot\left(-\mathrm{M}_{\mathrm{B}_{2} \mathrm{O}_{3}}\right)+\mathrm{z}_{\mathrm{BaO}} \cdot\left(-\mathrm{M}_{\mathrm{BaO}}\right)+\mathrm{z}_{\mathrm{CaO}} \cdot\left(-\mathrm{M}_{\mathrm{CaO}}\right)+\mathrm{z}_{\mathrm{Ce}_{2} \mathrm{O}_{3}} \cdot\left(-\mathrm{M}_{\mathrm{Ce}_{2} \mathrm{O}_{3}}\right) \\
& +\mathrm{z}_{\mathrm{Cr}_{2} \mathrm{O}_{3}} \cdot\left(-\mathrm{M}_{\mathrm{Cr}_{2} \mathrm{O}_{3}}\right)+\mathrm{z}_{\mathrm{Cs}_{2} \mathrm{O}_{3}} \cdot\left(-\mathrm{M}_{\mathrm{Cs}_{2} \mathrm{O}_{3}}\right)+\mathrm{z}_{\mathrm{CuO}} \cdot\left(-\mathrm{M}_{\mathrm{CuO}}\right)+\mathrm{z}_{\mathrm{Fe}_{2} \mathrm{O}_{3}} \cdot\left(-\mathrm{M}_{\mathrm{Fe}_{2} \mathrm{O}_{3}}\right)+\mathrm{z}_{\mathrm{K}_{2} \mathrm{O}} \cdot\left(-\mathrm{M}_{\mathrm{K}_{2} \mathrm{O}}\right) \\
& +\mathrm{z}_{\mathrm{La}_{2} \mathrm{O}_{3}} \cdot\left(-\mathrm{M}_{\mathrm{La}_{2} \mathrm{O}_{3}}\right)+\mathrm{z}_{\mathrm{Li}_{2} \mathrm{O}} \cdot\left(-\mathrm{M}_{\mathrm{Li}_{2} \mathrm{O}}\right)+\mathrm{z}_{\mathrm{MgO}} \cdot\left(-\mathrm{M}_{\mathrm{MgO}}\right)+\mathrm{z}_{\mathrm{MnO}} \cdot\left(-\mathrm{M}_{\mathrm{MnO}}\right)+\mathrm{z}_{\mathrm{MoO}_{3}} \cdot\left(-\mathrm{M}_{\mathrm{MoO}_{3}}\right) \\
& +\mathrm{z}_{\mathrm{Na}_{2} \mathrm{O}} \cdot\left(-\mathrm{M}_{\mathrm{Na}_{2} \mathrm{O}}\right)+\mathrm{z}_{\mathrm{Nd}_{2} \mathrm{O}_{3}} \cdot\left(-\mathrm{M}_{\mathrm{Nd}_{2} \mathrm{O}_{3}}\right)+\mathrm{z}_{\mathrm{NiO}} \cdot\left(-\mathrm{M}_{\mathrm{NiO}}\right)+\mathrm{z}_{\mathrm{P}_{2} \mathrm{O}_{5}} \cdot\left(-\mathrm{M}_{\mathrm{P}_{2} \mathrm{O}_{5}}\right)+\mathrm{Z}_{\mathrm{PbO}} \cdot\left(-\mathrm{M}_{\mathrm{PbO}}\right) \\
& +\mathrm{z}_{\mathrm{SiO}_{2}} \cdot\left(-\mathrm{M}_{\mathrm{SiO}_{2}}\right)+\mathrm{z}_{\mathrm{ThO}_{2}} \cdot\left(-\mathrm{M}_{\mathrm{ThO}_{2}}\right)+\mathrm{z}_{\mathrm{TiO}_{2}} \cdot\left(-\mathrm{M}_{\mathrm{TiO}_{2}}\right)+\mathrm{z}_{\mathrm{U}_{3} \mathrm{O}_{8}} \cdot\left(-\mathrm{M}_{\mathrm{U}_{3} \mathrm{O}_{8}}\right)+\mathrm{z}_{\mathrm{Y}_{2} \mathrm{O}_{3}} \cdot\left(-\mathrm{M}_{\mathrm{Y}_{2} \mathrm{O}_{3}}\right) \\
& +\mathrm{z}_{\mathrm{ZnO}} \cdot\left(-\mathrm{M}_{\mathrm{ZnO}}\right)+\mathrm{z}_{\mathrm{ZrO}_{2}} \cdot\left(-\mathrm{M}_{\mathrm{ZrO}_{2}}\right)-(-105) \geq 0
\end{aligned}
$$

Note that the transformation of the constraints into a form similar to equation (1) requires that the offset (the $\beta$ ) be expressed as a negative and that the a vector for the high "sum of oxides" constraint involves the negatives of the molecular weights. Table 3 provides the complete information for these two constraints in the form of the vectors and offsets supporting equation (1). 
Table 3. Vectors and Offset for the Sum of Oxide Constraints

\begin{tabular}{|c|c|c|c|}
\hline & $\begin{array}{c}\underline{\mathrm{z}}^{\mathrm{T}} \\
\text { Average }\end{array}$ & \multicolumn{2}{|c|}{ Transpose of a Vectors } \\
\hline Oxide & $\begin{array}{l}\text { Molar Oxide } \\
\text { Wt Fraction }\end{array}$ & $\underline{\mathrm{a}}^{\mathrm{T}}$ low consv & $\underline{\mathrm{a}}^{\mathrm{T}}$ high consv \\
\hline $\mathrm{Al}_{2} \mathrm{O}_{3}$ & $\mathrm{z}_{\mathrm{A} 12 \mathrm{O} 3}$ & 101.9612 & -101.9612 \\
\hline $\mathrm{B}_{2} \mathrm{O}_{3}$ & $\mathrm{z}_{\mathrm{B} 2 \mathrm{O} 3}$ & 69.6202 & -69.6202 \\
\hline $\mathrm{BaO}$ & $\mathrm{z}_{\mathrm{BaO}}$ & 153.3394 & -153.3394 \\
\hline $\mathrm{HCOO}$ & $\mathrm{z}_{\mathrm{HCOO}}$ & 0 & 0 \\
\hline $\mathrm{CaO}$ & $\mathrm{z}_{\mathrm{CaO}}$ & 56.0794 & -56.0794 \\
\hline $\mathrm{Ce}_{2} \mathrm{O}_{3}$ & $\mathrm{z}_{\mathrm{Ce} 2 \mathrm{O} 3}$ & 328.2382 & -328.2382 \\
\hline $\mathrm{NaCl}$ & $\mathrm{Z}_{\mathrm{NaCl}}$ & 0 & 0 \\
\hline $\mathrm{Cr}_{2} \mathrm{O}_{3}$ & $\mathrm{Z}_{\mathrm{Cr} 2 \mathrm{O} 3}$ & 151.9902 & -151.9902 \\
\hline $\mathrm{Cs}_{2} \mathrm{O}$ & $\mathrm{Z}_{\mathrm{Cs} 2 \mathrm{O}}$ & 281.8094 & -281.8094 \\
\hline $\mathrm{CuO}$ & $\mathrm{Z}_{\mathrm{CuO}}$ & 75.54390775 & -75.54390775 \\
\hline $\mathrm{NaF}$ & $\mathrm{Z}_{\mathrm{NaF}}$ & 0 & 0 \\
\hline $\mathrm{Fe}_{2} \mathrm{O}_{3}$ & $\mathrm{Z}_{\mathrm{Fe} 2 \mathrm{O} 3}$ & 159.6922 & -159.6922 \\
\hline $\mathrm{K}_{2} \mathrm{O}$ & $\mathrm{Z}_{\mathrm{K} 2 \mathrm{O}}$ & 94.2034 & -94.2034 \\
\hline $\mathrm{La}_{2} \mathrm{O}_{3}$ & $\mathrm{Z}_{\mathrm{La} 2 \mathrm{O} 3}$ & 325.8182 & -325.8182 \\
\hline $\mathrm{Li}_{2} \mathrm{O}$ & $\mathrm{Z}_{\mathrm{Li} 2 \mathrm{O}}$ & 29.8774 & -29.8774 \\
\hline $\mathrm{MgO}$ & $\mathrm{Z}_{\mathrm{MgO}}$ & 40.3114 & -40.3114 \\
\hline $\mathrm{MnO}$ & $\mathrm{Z}_{\mathrm{MnO}}$ & 70.9374 & -70.9374 \\
\hline $\mathrm{MoO}_{3}$ & $\mathrm{Z}_{\mathrm{MoO} 3}$ & 143.9382 & -143.9382 \\
\hline $\mathrm{NO}_{2}$ & $\mathrm{Z}_{\mathrm{NO} 2}$ & 0 & 0 \\
\hline $\mathrm{NO}_{3}$ & $\mathrm{Z}_{\mathrm{NO} 3}$ & 0 & 0 \\
\hline $\mathrm{Na}_{2} \mathrm{O}$ & $\mathrm{Z}_{\mathrm{Na} 2 \mathrm{O}}$ & 61.979 & -61.979 \\
\hline $\mathrm{Na}_{2} \mathrm{SO}_{4}$ & $\mathrm{Z}_{\mathrm{Na} 2 \mathrm{SO} 4}$ & 0 & 0 \\
\hline $\mathrm{Nd}_{2} \mathrm{O} 3$ & $\mathrm{Z}_{\mathrm{Nd} 2 \mathrm{O} 3}$ & 336.4782 & -336.4782 \\
\hline $\mathrm{NiO}$ & $\mathrm{Z}_{\mathrm{NiO}}$ & 74.7094 & -74.7094 \\
\hline $\mathrm{P}_{2} \mathrm{O}_{5}$ & $\mathrm{Z}_{\mathrm{P} 2 \mathrm{O} 5}$ & 141.9446 & -141.9446 \\
\hline $\mathrm{PbO}$ & $\mathrm{Z}_{\mathrm{PbO}}$ & 223.1894 & -223.1894 \\
\hline $\mathrm{SiO}_{2}$ & $\mathrm{Z}_{\mathrm{SiO} 2}$ & 60.0848 & -60.0848 \\
\hline $\mathrm{ThO}_{2}$ & $\mathrm{Z}_{\mathrm{ThO} 2}$ & 264.0368 & -264.0368 \\
\hline $\mathrm{TiO}_{2}$ & $\mathrm{Z}_{\mathrm{TiO} 2}$ & 79.8988 & -79.8988 \\
\hline $\mathrm{U}_{3} \mathrm{O}_{8}$ & $\mathrm{Z}_{\mathrm{U} 3 \mathrm{O} 8}$ & 842.0852 & -842.0852 \\
\hline $\mathrm{Y}_{2} \mathrm{O}_{3}$ & $\mathrm{Z}_{\mathrm{Y} 2 \mathrm{O} 3}$ & 225.8082 & -225.8082 \\
\hline $\mathrm{ZnO}$ & $\mathrm{Z}_{\mathrm{ZnO}}$ & 81.3694 & -81.3694 \\
\hline $\mathrm{ZrO}_{2}$ & $\mathrm{Z}_{\mathrm{ZrO} 2}$ & 123.2188 & -123.2188 \\
\hline \multicolumn{2}{|c|}{ Offset $(\beta)$} & $\begin{array}{c}95 \\
\beta_{\text {low consv }}\end{array}$ & $\begin{array}{c}-105 \\
\beta_{\text {high consv }}\end{array}$ \\
\hline
\end{tabular}


Using the vectors of Table 3 to write these constraints for the sum of oxides in the form of equation (1) yields:

Low Conservation: $\quad \underline{\mathrm{za}}_{\text {low consv }}^{\mathrm{T}}-\beta_{\text {low consv }} \geq 0 \quad$ or $\quad \underline{\mathrm{za}} \underline{\mathrm{a}}_{\text {low consv }}^{\mathrm{T}}-95 \geq 0$

and

High Conservation: $\quad \underline{\mathrm{za}}_{\text {high consv }}^{\mathrm{T}}-\beta_{\text {high consv }} \geq 0 \quad$ or $\quad \underline{\mathrm{za}}_{\text {high consv }}^{\mathrm{T}}-(-105) \geq 0$

For a given average composition to be in the MAR (the DWPF operating window), it must satisfy both of these "sum of oxide" constraints as given above.

\subsection{SolubiLITY CONSTRAINTS}

As already mentioned the solubility constraint associated with $\mathrm{P}_{2} \mathrm{O}_{5}$ was removed from the scope of the PCCS control system as part of this revision of the report [8]. Rewriting the remaining solubility constraints of Table 2 using the molar oxide notation yields the following set of inequalities (the reference for each constraint is also indicated to the right of each of these inequalities):

Solubilities: $\quad \mathrm{Z}_{\mathrm{TiO}_{2}} \mathrm{M}_{\mathrm{TiO}_{2}} \leq 1.0$

$$
\mathrm{Z}_{\mathrm{NaCl}} \mathrm{M}_{\mathrm{NaCl}} \leq 1.0
$$

$\mathrm{Z}_{\mathrm{NaF}} \mathrm{M}_{\mathrm{NaF}} \leq 1.0$

$$
\mathrm{Z}_{\mathrm{Cr}_{2} \mathrm{O}_{3}} \mathrm{M}_{\mathrm{Cr}_{2} \mathrm{O}_{3}} \leq 0.3
$$

$$
\begin{aligned}
& \left\{\mathrm{z}_{\mathrm{SO}_{4}} \mathrm{M}_{\mathrm{SO}_{4}} \leq 0.40 \text { or } \mathrm{z}_{\mathrm{Na}_{2} \mathrm{SO}_{4}} \mathrm{M}_{\mathrm{Na}_{2} \mathrm{SO}_{4}} \leq 0.59\right\} \\
& \left\{\mathrm{z}_{\mathrm{Cu}} \mathrm{M}_{\mathrm{Cu}} \leq 0.5 \text { or } \mathrm{z}_{\mathrm{CuO}} \mathrm{M}_{\mathrm{Cu}} \leq 0.5\right\} \text { where } \mathrm{z}_{\mathrm{Cu}} \equiv \mathrm{z}_{\mathrm{CuO}}
\end{aligned}
$$

where as before $\mathbf{M}_{\text {oxide }}$ represents the molecular weight of the indicated oxide and $\mathrm{z}_{\text {oxide }}$ represents the "average" molar concentration for the indicated oxide.

Transforming these constraints to follow the form used in equation (1) yields:

Solubilities: $\quad \mathrm{Z}_{\mathrm{TiO}_{2}}\left(-\mathrm{M}_{\mathrm{TiO}_{2}}\right)-(-1.0) \geq 0$

$$
\begin{aligned}
& \mathrm{Z}_{\mathrm{NaCl}}\left(-\mathrm{M}_{\mathrm{NaCl}}\right)-(-1.0) \geq 0 \\
& \mathrm{Z}_{\mathrm{NaF}}\left(-\mathrm{M}_{\mathrm{NaF}}\right)-(-1.0) \geq 0
\end{aligned}
$$$$
\mathrm{Z}_{\mathrm{Cr}_{2} \mathrm{O}_{3}}\left(-\mathrm{M}_{\mathrm{Cr}_{2} \mathrm{O}_{3}}\right)-(-0.3) \geq 0
$$$$
\mathrm{Z}_{\mathrm{Na}_{2} \mathrm{SO}_{4}}\left(-\mathrm{M}_{\mathrm{Na}_{2} \mathrm{SO}_{4}}\right)-(-0.59) \geq 0
$$$$
\mathrm{z}_{\mathrm{CuO}}\left(-\mathrm{M}_{\mathrm{Cu}}\right)-(-0.5) \geq 0
$$

The shorthand notation when applied to these constraints yields an a vector with only a single "active" component (i.e., only one oxide of the vector $\underline{z}$ is involved in the constraint). Also, note in the $\mathrm{Cu}$ constraint, the multiplier is the molecular weight of elemental $\mathrm{Cu}$, since the solubility constraint is a constraint on the elemental $\mathrm{Cu}$ in the wasteform. 
To complete the assessment of these constraints for a given composition requires that the appropriate uncertainties be accounted for in the constraints. Since no propertycomposition models are utilized in meeting the solubility constraints, no property model uncertainty need be applied. This leaves only measurement uncertainty for each of these constraints. And since each of the constraints involves a linear combination of the $\underline{z}$ vector of component concentrations, the measurement uncertainty can be addressed as described in Appendix B.

Using the approach of Appendix B, let $\underline{\mathrm{Z}}_{\mathrm{a}} \underline{\mathrm{a}}^{\mathrm{T}}$ represent the linear combination of the average molar concentrations (based on $n$ samples) of any one of the solubility constraints and $\beta$ represent the corresponding offset (see Table 4 for a complete listing of the vectors and offsets for these solubility constraints); then the constraint with measurement uncertainty would be of the form:

$$
\underline{\mathrm{z}}_{\mathrm{n}} \underline{\mathrm{a}}^{\mathrm{T}}-\beta-\mathrm{t}_{\alpha}(\mathrm{m}-1) \sqrt{\frac{\underline{\mathrm{aS}}_{\underline{\mathrm{a}}^{\mathrm{T}}}^{\mathrm{n}}}{\mathrm{n}}} \geq 0
$$

where $\quad t_{\alpha}(\mathrm{m}-1)$ represents the upper $100 \alpha \%$ tail of the Student's t distribution with $\mathrm{m}-1$ degrees of freedom and

$$
\frac{\underline{\mathrm{a} S \underline{\mathrm{a}}^{\mathrm{T}}}}{\mathrm{n}} \equiv \operatorname{maximum}\left[\begin{array}{l}
\left.\frac{\left(\underline{\mathrm{a}}_{\mathrm{i}}\right) \mathbf{S}_{\mathrm{m}}\left(\underline{\mathrm{a}}_{\mathrm{i}}\right)^{\mathrm{T}}}{\mathrm{n}}=\frac{1}{\mathrm{n}} \sum_{\mathrm{j}=0}^{\mathrm{q}-1} \sum_{\mathrm{k}=0}^{\mathrm{q}-1} \underline{\mathrm{a}}_{\mathrm{i}}\right)_{\mathrm{j}}\left(\underline{\mathrm{a}}_{\mathrm{i}}\right)_{\mathrm{k}}\left(\mathbf{S}_{\mathrm{m}}\right)_{\mathrm{j}, \mathrm{k}} \\
\frac{\left(\underline{\mathrm{a}}_{\mathrm{i}}\right) \mathbf{S}_{\mathrm{n}}\left(\underline{\mathrm{a}}_{\mathrm{i}}\right)^{\mathrm{T}}}{\mathrm{n}}=\frac{1}{\mathrm{q}} \sum_{\mathrm{j}=0}^{\mathrm{q}-1} \sum_{\mathrm{k}=0}^{\mathrm{q}-1}\left(\underline{\mathrm{a}}_{\mathrm{i}}\right)_{\mathrm{j}}\left(\underline{\mathrm{a}}_{\mathrm{i}}\right)_{\mathrm{k}}\left(\mathbf{S}_{\mathrm{n}}\right)_{\mathrm{j}, \mathrm{k}}
\end{array}\right]
$$

with $\mathrm{S}_{\mathrm{m}}$ and $\mathrm{S}_{\mathrm{n}}$ representing the covariance matrices (an absolute based upon historical data versus a relative based upon the current $\underline{z}$ vector, respectively) as described in Appendix B. 
Table 4. Vectors and Offsets for Waste Solubility Constraints

\begin{tabular}{|c|c|c|c|c|c|c|c|}
\hline & \multirow{3}{*}{\begin{tabular}{|c|}
$\underline{\mathrm{Z}}^{\mathrm{I}}$ \\
Average \\
Molar Oxide \\
Wt Fraction
\end{tabular}} & \multirow{2}{*}{\multicolumn{6}{|c|}{ Transpose of a Vector for Each of the Solubility Constraints }} \\
\hline & & & & & & & \\
\hline Oxide & & $\underline{\underline{a}}^{\mathrm{T}} \mathrm{TiO}_{2}$ & $\underline{\mathrm{a}^{\mathrm{T}} \mathrm{NaCl}}$ & $\underline{a}^{\mathrm{T}} \mathrm{NaF}$ & $\underline{\underline{a}}^{\mathrm{T}} \mathrm{rr}_{2} \mathrm{O} 3$ & $\underline{a}^{\mathrm{T}}{ }_{\mathrm{Na} 2 \mathrm{SO}}$ & $\underline{a}^{\mathrm{T}} \mathrm{Cu}$ \\
\hline $\mathrm{Al}_{2} \mathrm{O}_{3}$ & $\mathrm{z}_{\mathrm{A} 12 \mathrm{O} 3}$ & 0 & 0 & 0 & 0 & 0 & 0 \\
\hline $\mathrm{B}_{2} \mathrm{O}_{3}$ & $\mathrm{Z}_{\mathrm{B} 2 \mathrm{O} 3}$ & 0 & 0 & 0 & 0 & 0 & 0 \\
\hline $\mathrm{BaO}$ & $\mathrm{Z}_{\mathrm{BaO}}$ & 0 & 0 & 0 & 0 & 0 & 0 \\
\hline $\mathrm{HCOO}$ & $\mathrm{Z}_{\mathrm{HCOO}}$ & 0 & 0 & 0 & 0 & 0 & 0 \\
\hline $\mathrm{CaO}$ & $\mathrm{z}_{\mathrm{CaO}}$ & 0 & 0 & 0 & 0 & 0 & 0 \\
\hline $\mathrm{Ce}_{2} \mathrm{O}_{3}$ & $\mathrm{Z}_{\mathrm{Ce} 2 \mathrm{O} 3}$ & 0 & 0 & 0 & 0 & 0 & 0 \\
\hline $\mathrm{NaCl}$ & $\mathrm{Z}_{\mathrm{NaCl}}$ & 0 & -58.4428 & 0 & 0 & 0 & 0 \\
\hline $\mathrm{Cr}_{2} \mathrm{O}_{3}$ & $\mathrm{Z}_{\mathrm{Cr} 2 \mathrm{O} 3}$ & 0 & 0 & 0 & -151.9902 & 0 & 0 \\
\hline $\mathrm{Cs}_{2} \mathrm{O}$ & $\mathrm{Z}_{\mathrm{Cs} 2 \mathrm{O}}$ & 0 & 0 & 0 & 0 & 0 & 0 \\
\hline $\mathrm{CuO}$ & $\mathrm{Z}_{\mathrm{CuO}}$ & 0 & 0 & 0 & 0 & 0 & -63.5383 \\
\hline $\mathrm{NaF}$ & $\mathrm{Z}_{\mathrm{NaF}}$ & 0 & 0 & -41.9882 & 0 & 0 & 0 \\
\hline $\mathrm{Fe}_{2} \mathrm{O}_{3}$ & $\mathrm{Z}_{\mathrm{Fe} 2 \mathrm{O} 3}$ & 0 & 0 & 0 & 0 & 0 & 0 \\
\hline $\mathrm{K}_{2} \mathrm{O}$ & $\mathrm{Z}_{\mathrm{K} 2 \mathrm{O}}$ & 0 & 0 & 0 & 0 & 0 & 0 \\
\hline $\mathrm{La}_{2} \mathrm{O}_{3}$ & $\mathrm{Z}_{\mathrm{La} 2 \mathrm{O} 3}$ & 0 & 0 & 0 & 0 & 0 & 0 \\
\hline $\mathrm{Li}_{2} \mathrm{O}$ & $\mathrm{Z}_{\mathrm{Li} 2 \mathrm{O}}$ & 0 & 0 & 0 & 0 & 0 & 0 \\
\hline $\mathrm{MgO}$ & $\mathrm{Z}_{\mathrm{MgO}}$ & 0 & 0 & 0 & 0 & 0 & 0 \\
\hline $\mathrm{MnO}$ & $\mathrm{Z}_{\mathrm{MnO}}$ & 0 & 0 & 0 & 0 & 0 & 0 \\
\hline $\mathrm{MoO}_{3}$ & $\mathrm{Z}_{\mathrm{MoO} 3}$ & 0 & 0 & 0 & 0 & 0 & 0 \\
\hline $\mathrm{NO}_{2}$ & $\mathrm{Z}_{\mathrm{NO} 2}$ & 0 & 0 & 0 & 0 & 0 & 0 \\
\hline $\mathrm{NO}_{3}$ & $\mathrm{Z}_{\mathrm{NO} 3}$ & 0 & 0 & 0 & 0 & 0 & 0 \\
\hline $\mathrm{Na}_{2} \mathrm{O}$ & $\mathrm{Z}_{\mathrm{Na} 2 \mathrm{O}}$ & 0 & 0 & 0 & 0 & 0 & 0 \\
\hline $\mathrm{Na}_{2} \mathrm{SO}_{4}$ & $\mathrm{Z}_{\mathrm{Na} 2 \mathrm{SO} 4}$ & 0 & 0 & 0 & 0 & -142.0412 & 0 \\
\hline $\mathrm{Nd}_{2} \mathrm{O} 3$ & $\mathrm{Z}_{\mathrm{Nd} 2 \mathrm{O} 3}$ & 0 & 0 & 0 & 0 & 0 & 0 \\
\hline $\mathrm{NiO}$ & $\mathrm{Z}_{\mathrm{NiO}}$ & 0 & 0 & 0 & 0 & 0 & 0 \\
\hline $\mathrm{P}_{2} \mathrm{O}_{5}$ & $Z_{\mathrm{P} 205}$ & 0 & 0 & 0 & 0 & 0 & 0 \\
\hline $\mathrm{PbO}$ & $\mathrm{Z}_{\mathrm{PbO}}$ & 0 & 0 & 0 & 0 & 0 & 0 \\
\hline $\mathrm{SiO}_{2}$ & $\mathrm{Z}_{\mathrm{SiO} 2}$ & 0 & 0 & 0 & 0 & 0 & 0 \\
\hline $\mathrm{ThO}_{2}$ & $\mathrm{Z}_{\mathrm{ThO} 2}$ & 0 & 0 & 0 & 0 & 0 & 0 \\
\hline $\mathrm{TiO}_{2}$ & $\mathrm{Z}_{\mathrm{TiO} 2}$ & -79.8988 & 0 & 0 & 0 & 0 & 0 \\
\hline $\mathrm{U}_{3} \mathrm{O}_{8}$ & $\mathrm{Z}_{\mathrm{U} 308}$ & 0 & 0 & 0 & 0 & 0 & 0 \\
\hline $\mathrm{Y}_{2} \mathrm{O}_{3}$ & $Z_{\mathrm{Y} 203}$ & 0 & 0 & 0 & 0 & 0 & 0 \\
\hline $\mathrm{ZnO}$ & $\mathrm{Z}_{\mathrm{ZnO}}$ & 0 & 0 & 0 & 0 & 0 & 0 \\
\hline $\mathrm{ZrO}_{2}$ & $\mathrm{Z}_{\mathrm{ZrO} 2}$ & 0 & 0 & 0 & 0 & 0 & 0 \\
\hline & $\Omega f f_{\operatorname{cet}}(\Omega)$ & -1 & -1 & -1 & -0.3 & -0.59 & -0.5 \\
\hline & Oftset $(\beta)$ & $\beta_{\mathrm{TiO} 2}$ & $\beta_{\mathrm{NaCl}}$ & $\beta_{\mathrm{NaF}}$ & $\beta_{\mathrm{Cr} 2 \mathrm{O} 3}$ & $\beta_{\mathrm{Na} 2 \mathrm{SO} 4}$ & $\beta_{\mathrm{Cu}}$ \\
\hline
\end{tabular}

This approach leads to the following expressions for the MAR associated with the solubility constraints.

$\underline{\mathrm{z}}_{\mathrm{n}} \underline{\mathrm{a}}_{\mathrm{TiO}_{2}}^{\mathrm{T}}-(-1.0)-\mathrm{t}_{\alpha}(\mathrm{m}-1) \sqrt{\frac{\underline{\mathrm{a}}_{\mathrm{TiO}_{2}} \mathbf{S}_{\underline{\mathrm{a}}_{\mathrm{TiO}}}^{\mathrm{T}}}{\mathrm{n}}} \geq 0$ 
$\underline{\mathrm{z}}_{\mathrm{n}} \underline{\mathrm{a}}_{\mathrm{NaCl}}^{\mathrm{T}}-(-1.0)-\mathrm{t}_{\alpha}(\mathrm{m}-1) \sqrt{\frac{\underline{\mathrm{a}}_{\mathrm{NaCl}} \mathbf{S} \underline{\mathrm{a}}_{\mathrm{NaCl}}^{\mathrm{T}}}{\mathrm{n}}} \geq 0$

$\underline{\mathrm{z}}_{\mathrm{n}} \underline{\mathrm{a}}_{\mathrm{NaF}}^{\mathrm{T}}-(-1.0)-\mathrm{t}_{\alpha}(\mathrm{m}-1) \sqrt{\frac{\underline{\mathrm{a}}_{\mathrm{NaF}} \mathbf{S} \underline{\mathrm{a}}_{\mathrm{NaF}}^{\mathrm{T}}}{\mathrm{n}}} \geq 0$

$\underline{\mathrm{z}}_{\mathrm{n}} \underline{\mathrm{a}}_{\mathrm{Cr}_{2} \mathrm{O}_{3}}^{\mathrm{T}}-(-0.3)-\mathrm{t}_{\alpha}(\mathrm{m}-1) \sqrt{\frac{\underline{\mathrm{a}}_{\mathrm{Cr}_{2} \mathrm{O}_{3}} \mathbf{S} \underline{\mathrm{a}}_{\mathrm{Cr}_{2} \mathrm{O}_{3}}^{\mathrm{T}}}{\mathrm{n}}} \geq 0$

$\underline{\mathrm{z}}_{\mathrm{n}} \underline{\mathrm{a}}_{\mathrm{Na}_{2} \mathrm{SO}_{4}}^{\mathrm{T}}-(-0.3)-\mathrm{t}_{\alpha}(\mathrm{m}-1) \sqrt{\frac{\underline{\mathrm{a}}_{\mathrm{Na}_{2} \mathrm{SO}_{4}} \mathrm{~S}_{\mathrm{a}^{\mathrm{a}} \mathrm{Na}_{2} \mathrm{SO}_{4}}^{\mathrm{T}}}{\mathrm{n}}} \geq 0$

$\underline{\mathrm{z}}_{\mathrm{n}} \underline{\mathrm{a}}_{\mathrm{Cu}}^{\mathrm{T}}-(-1.0)-\mathrm{t}_{\alpha}(\mathrm{m}-1) \sqrt{\frac{\underline{\mathrm{a}}_{\mathrm{Cu}} \mathbf{S} \underline{\mathrm{a}}_{\mathrm{Cu}}^{\mathrm{T}}}{\mathrm{n}}} \geq 0$

If all of these MAR constraints are satisfied, then $\underline{z}_{n}$ is acceptable for all of the waste solubility constraints. Note that the nominal 95\% confidence level (equal to 100[1- $\alpha] \%$ ) for the solubility constraints can be adjusted based upon management discretion.

\subsection{Constraints Associated With Product Quality}

Several of the constraints in Table 2 are associated with the quality of the DWPF wasteform. For vitrified HLW, a quality product is a durable product, one that is resistant to leaching. The Product Consistency Test (PCT) [3], which yields normalized boron, lithium, and sodium releases, is used to assess waste glass durability. Since the durability of DWPF's glass product cannot be measured in situ, durability-composition models are used to predict the PCT response for the elements of interest. Such a model was developed for each of the three elements of interest, and the form of these durability models may be represented as [1]:

$$
\begin{array}{ll}
\text { Durability: } & \log \left[\mathrm{NC}_{\mathrm{i}}\right]=\mathrm{m}_{\mathrm{d}} \mathrm{c}_{\mathrm{d}}+\mathrm{b}_{\mathrm{d}} \\
& \mathrm{c}_{\mathrm{d}} \equiv \sum_{\text {major oxid es }} \mathrm{z}_{\text {oxide }} \ddot{\mathrm{A}} \mathrm{G}_{\text {oxide }} .
\end{array}
$$

$¥ \quad$ In general, this equation (with $\mathrm{m}_{\mathrm{d}}$ being the estimated slope and $\mathrm{b}_{\mathrm{d}}$ the estimated intercept) represents the B, Li, and Na releases. Specifically, $c_{\mathrm{d}}$ equals $\mathrm{G}_{\mathrm{p}}$, the free energy of hydration (in $\mathrm{kcal} / \mathrm{mole}$ ) and thus uses all oxides described in Table IX of Ref. 1. A reasonable heuristic rule [2] is to use those oxides expected to be present in the DWPF glass product in appreciable amounts, i.e., $0.5 \mathrm{wt} \%$. The individual coefficients for $\mathrm{G}_{\mathrm{p}}$ are obtained by presubtracting (as described in [1]) the silica free energy, $\mathrm{GSiO}_{2}$, from the free energy for each oxide expected to form a silicate, $\mathrm{G}_{\text {oxide. }}$. The coefficient necessary for copper is defined uniquely in Section 6. 
Constraints are derived from these models that restrict the DWPF glass compositions to those whose predicted PCT responses are "2-sigma" better than those of EA. Figure 1 provides an illustration of these durability models. The fitted model (negatively sloped straight line) for boron is shown along with an upper (curved) 95\% prediction limit. A cluster of points representing EA PCT results for boron is indicated. More will be said regarding this figure and the approach used to develop and implement the durability constraints in the discussions that follow.

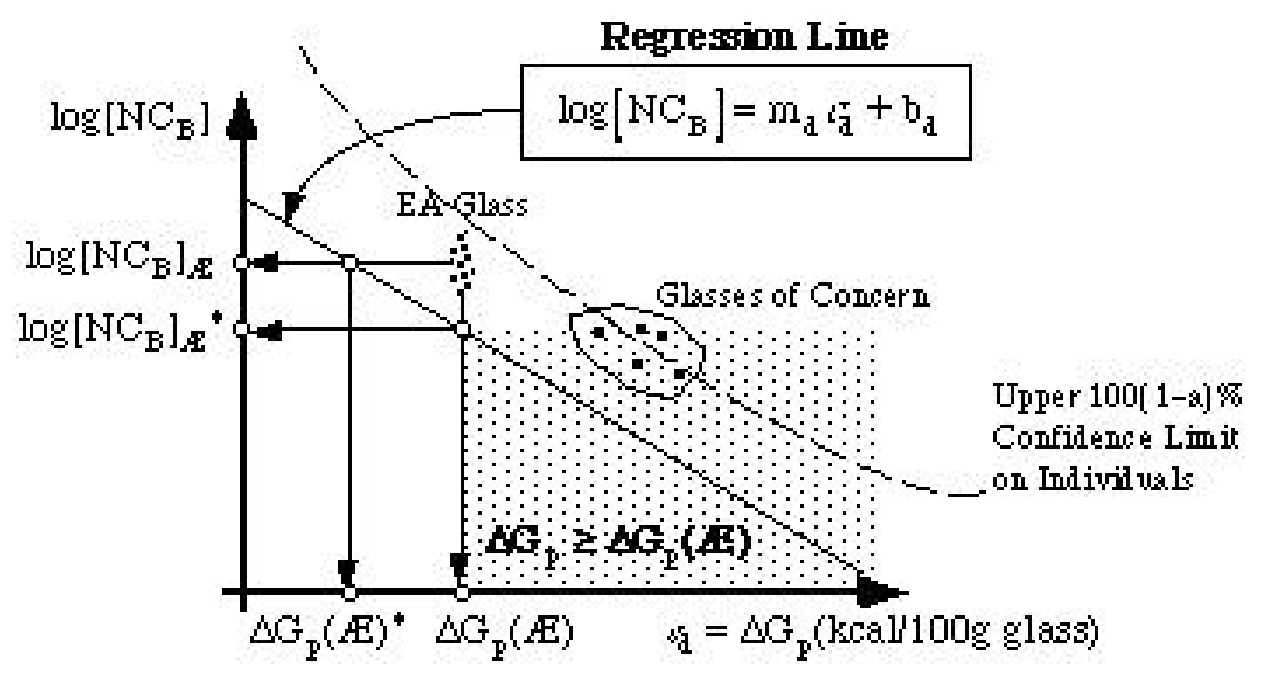

Figure 1. The PCT-Based Durability Regression Line for Boron Release

Furthermore, the glass must be homogeneous for the first-principles models represented in Figure 1 to be descriptive. To assure homogeneous glass, the homogeneity constraint [5] that appears in Table 2 was included as part of the DWPF control strategy. This constraint was developed using glass information available at the time of the study, which led to a pair of additional constraints: the low and high frit loading constraints. This pair of constraints was used to restrict glass compositions to a region for which the homogeneity constraint was deemed applicable [1].

One additional constraint of Table 2 is associated with the durability of the DWPF wasteform, the alumina constraint. When the durability regression models were applied to the data used for model validation, ${ }^{\dagger}$ the $\mathrm{B}$, $\mathrm{Li}$, and $\mathrm{Na}$ releases for glasses representative of those that will be produced in DWPF were reasonably well predicted as a function of $\mathrm{G}_{p}$ [1]. Furthermore, the PCT results of glasses from the DWPF Waste Qualification Runs were within the prediction intervals of these correlations. However, there appears to be at least one separate population of glasses used for model development whose leach results are significantly underpredicted. Most of these glasses were characterized by low concentrations of alumina. Therefore, DWPF must restrict the

These glasses were distinct from those used to develop the regression models for B, Li, and Na PCT releases. 
compositional range over which the correlations are applied to avoid production of lowalumina glasses.

Five glasses are depicted in Figure 1 whose PCT results lie along the upper prediction limit for the regression model (i.e., their PCT releases are significantly underpredicted). Each of these glasses contains less than $3 \mathrm{wt} \%$ alumina. The apparent cause of the inability to predict the release from glasses with low alumina contents is the significantly greater $\mathrm{pH}$ values of those glasses with large iron to alumina ratios.

For example, glasses IDMS PX-1 (high $\mathrm{Fe}_{2} \mathrm{O}_{3}$ ) and $\mathrm{AH} 202 \mathrm{FE}$ (low $\mathrm{Al}_{2} \mathrm{O}_{3}$ ) will be compared. Both of these glasses, whose compositions are provided in Table 5, were used in durability model development. As shown in Table 6, these glasses have very similar predicted PCT releases (as indicated by their nearly identical $\mathrm{G}_{\mathrm{p}}$ values); however, they possess very different measured releases. The measured $\mathrm{pH}$ values of the leachates from these two glasses were 9.4 for the PX-1 glass and 10.1 for the AH202FE glass.

Table 5. Compositions of Two Glasses Used for Durability Model Development $§$

\begin{tabular}{lcccccccccccccc}
\hline Glass/Wt\% & $\mathrm{Al}_{2} \mathrm{O}_{3}$ & $\mathrm{~B}_{2} \mathrm{O}_{3}$ & $\mathrm{CaO}$ & $\mathrm{Cr}_{2} \mathrm{O}_{3}$ & $\mathrm{Fe}_{2} \mathrm{O}_{3}$ & $\mathrm{FeO}$ & $\mathrm{K}_{2} \mathrm{O}$ & $\mathrm{MgO}$ & $\mathrm{MnO}$ & $\mathrm{Na}_{2} \mathrm{O}$ & $\mathrm{Li}_{2} \mathrm{O}$ & $\mathrm{NiO}$ & $\mathrm{SiO}_{2}$ & $\mathrm{TiO}_{2}$ \\
\hline \hline IDMS PX-1 & 4.96 & 7.36 & 1.50 & 0.55 & 11.17 & - & 3.03 & 1.44 & 3.26 & 10.02 & 4.28 & 1.71 & 50.58 & - \\
AH202FE & 1.36 & 7.08 & 0.96 & - & 9.62 & 6.28 & 3.28 & 1.26 & 0.95 & 7.62 & 4.27 & 2.73 & 52.55 & 1.72 \\
\hline
\end{tabular}

$\S$ Only those oxides in quantities greater than $0.5 \mathrm{wt} \%$ have been presented in Table 5 [1].

Table 6. pH, Gp, and PCT Releases for IDMS PX-1 and AH202FE

\begin{tabular}{lccrrr}
\hline Glass & $\begin{array}{c}\text { Measured } \\
\mathrm{pH}\end{array}$ & $\begin{array}{c}\mathrm{G}_{\mathrm{p}} \\
(\mathrm{kcal} / \mathrm{mole})\end{array}$ & $\begin{array}{c}\text { Measured } \\
\log \left[\mathrm{NC}_{\mathrm{B}}\right]\end{array}$ & $\begin{array}{c}\text { Measured } \\
\log \left[\mathrm{NC}_{\mathrm{Li}}\right]\end{array}$ & $\begin{array}{c}\text { Measured } \\
\log \left[\mathrm{NC}_{\mathrm{Na}}\right]\end{array}$ \\
\hline \hline IDMS PX-1 & 9.4 & -11.001 & -0.1651 & -0.1459 & -0.1441 \\
AH202FE & 10.1 & -11.029 & 0.4988 & 0.4052 & 0.4323 \\
\hline
\end{tabular}

The major difference in the compositions of these glasses is that the PX-1 glass contains almost four times more alumina than AH202FE. (In fact, PX-1 has slightly more alkali and less silica suggesting that the observed $\mathrm{pH}$ values should be in the opposite order.) As implied by Appendix $\mathrm{H}$ of reference 3, alumina is very effective as a buffer in the range of $\mathrm{pH}$ values normally encountered in PCT testing (i.e., 9 - 12). Thus the absolute amount of alumina in a glass plays an important role in regulating the leachate $\mathrm{pH}$ and hence the PCT results. As evident from Appendix B in reference 3, the amount of alumina in the glasses used for model development varied by almost an order of magnitude (i.e., from a low of 1.36 to a high of $13.4 \mathrm{wt} \%$ ). Thus, the buffering capacity of these glasses also varied widely.

To account for this effect of alumina on leaching, DWPF has elected to constrain itself to glasses which contain at least $3 \mathrm{wt} \%$ alumina (i.e., $\mathrm{g} \mathrm{Al}_{2} \mathrm{O}_{3} / 100 \mathrm{~g}$ glass $3.0 \%$ ) as indicated in Table 2. If this additional constraint is used to prune the set of glasses used 
for model development, the PCT results of the remaining glasses all lie below the upper prediction limit of the correlations.

DWPF has chosen to show that the normalized boron, lithium, and sodium releases for DWPF glasses are at least "2-sigma" less than the corresponding releases for the Environmental Assessment (EA) glass based upon the PCT leach test. This implies that these releases must be controlled to at least the $95 \%$ confidence level. Therefore, a 95\% level of confidence is applied to all uncertainties (both property and measurement, where appropriate) associated with each of the constraints supporting the durability assessment. These constraints are discussed in the subsections that follow.

\subsubsection{Homogeneity, Frit LoAding, ANd Alumina Constraints}

Four constraints that support the assessment of durability of the DWPF wasteform are composition-only constraints. That is, they do not rely on property-composition models, and they can be most simply expressed in terms of mass oxide concentrations (i.e., $\mathrm{x}_{\text {oxide }}$ $\equiv \mathrm{g}$ oxide/100g glass). Expressing these constraints initially as mass oxides yields (the reference for each constraint except alumina, which was developed as part of this report, is provided to its right):

$$
\text { Homogeneity: }{ }^{\dagger} \quad a_{s} c_{s}+a_{f} c_{f}+b_{h} \leq 0
$$

where

$$
\begin{aligned}
& \mathrm{c}_{\mathrm{s}} \equiv \mathrm{x}_{\mathrm{Al}_{2} \mathrm{O}_{3}}+\mathrm{x}_{\mathrm{Fe}_{2} \mathrm{O}_{3}}+\mathrm{x}_{\mathrm{Nd}_{2} \mathrm{O}_{3}}+\mathrm{x}_{\mathrm{Ce}_{2} \mathrm{O}_{3}}+\mathrm{x}_{\mathrm{La}_{2} \mathrm{O}_{3}} \\
& +\mathrm{x}_{\mathrm{Y}_{2} \mathrm{O}_{3}}+\mathrm{x}_{\mathrm{CaO}}+\mathrm{x}_{\mathrm{MoO}_{3}} \\
& \mathrm{c}_{\mathrm{f}} \equiv \mathrm{x}_{\mathrm{Cs}_{2} \mathrm{O}}+\mathrm{x}_{\mathrm{Li}_{2} \mathrm{O}}+\mathrm{x}_{\mathrm{K}_{2} \mathrm{O}}+\mathrm{x}_{\mathrm{Na}_{2} \mathrm{O}}+\mathrm{x}_{\mathrm{B}_{2} \mathrm{O}_{3}}+\mathrm{x}_{\mathrm{SiO}_{2}} \\
& \mathrm{~b}_{\mathrm{h}}=210.9203, \mathrm{a}_{\mathrm{s}}=-5.6478 \text { and } \mathrm{a}_{\mathrm{f}}=-1.6035 \text { are constants from the } \\
& \text { discriminant analysis conducted on the set of available homogeneous } \\
& \text { and phase-separated glasses. }
\end{aligned}
$$

Alumina $\quad \mathrm{x}_{\mathrm{Al}_{2} \mathrm{O}_{3}} \geq 3.0$

Frit Loading: $\quad 70 \leq \mathrm{c}_{\mathrm{f}} \leq 85 \mathrm{wt} \%$

Re-expressing the constraints in molar oxide yields:

Homogeneity: $:^{\dagger \dagger} \quad \underline{\mathrm{z}}_{\mathrm{h}} \underline{\mathrm{a}}_{\mathrm{h}}{ }^{\mathrm{T}} \leq-\mathrm{b}_{\mathrm{h}}$

The homogeneity constraint is not based upon property prediction; instead, it is based upon a discriminant function derived from composition and reasonable prior and posterior probabilities. Specifically, a statistical discriminant analysis was used to define the homogeneity constraint based upon variables defined by the glass chemist involved in the project [5]. The original definition of $\mathrm{C}_{\mathrm{S}}$ included an additional term: $\mathrm{x}_{\mathrm{FeO}}$ as $\mathrm{x}_{\mathrm{Fe}_{2} \mathrm{O}_{3}}$; however, as described in Section 6, all elemental iron is properly converted to $\mathrm{Fe}_{2} \mathrm{O}_{3}$ (i.e., considered oxidized) and thus this term is identically zero and not included in the definition. 
Alumina:

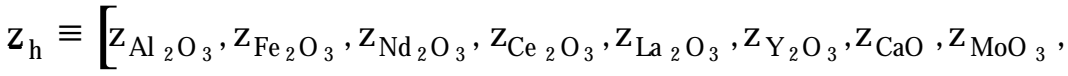

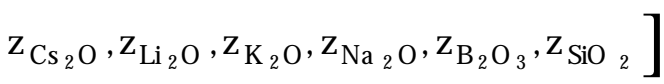

$$
\begin{aligned}
& \underline{\mathrm{a}}_{\mathrm{h}} \equiv \mathrm{a}_{\mathrm{s}} \mathrm{M}_{\mathrm{Al}_{2} \mathrm{O}_{3}}, \mathrm{a}_{\mathrm{s}} \mathrm{M}_{\mathrm{Fe}_{2} \mathrm{O}_{3}}, \mathrm{a}_{\mathrm{s}} \mathrm{M}_{\mathrm{Nd}_{2} \mathrm{O}_{3}}, \mathrm{a}_{\mathrm{s}} \mathrm{M}_{\mathrm{Ce}_{2} \mathrm{O}_{3}}, \mathrm{a}_{\mathrm{s}} \mathrm{M}_{\mathrm{La}_{2} \mathrm{O}_{3}}, \mathrm{a}_{\mathrm{s}} \mathrm{M}_{\mathrm{Y}_{2} \mathrm{O}_{3}}, \mathrm{a}_{\mathrm{s}} \mathrm{M}_{\mathrm{CaO}} \text {, } \\
& \left.a_{\mathrm{s}} \mathrm{M}_{\mathrm{MoO}_{3}}, a_{\mathrm{f}} \mathrm{M}_{\mathrm{Cs}_{2} \mathrm{O}}, \mathrm{a}_{\mathrm{f}} \mathrm{M}_{\mathrm{Li}_{2} \mathrm{O}}, \mathrm{a}_{\mathrm{f}} \mathrm{M}_{\mathrm{K}_{2} \mathrm{O}}, \mathrm{a}_{\mathrm{f}} \mathrm{M}_{\mathrm{Na}_{2} \mathrm{O}}, \mathrm{a}_{\mathrm{f}} \mathrm{M}_{\mathrm{B}_{2} \mathrm{O}_{3}}, \mathrm{a}_{\mathrm{f}} \mathrm{M}_{\mathrm{SiO}_{2}}\right]
\end{aligned}
$$

$$
\mathrm{z}_{\mathrm{Al}_{2} \mathrm{O}_{3}} \mathrm{M}_{\mathrm{Al}_{2} \mathrm{O}_{3}} \geq 3.0
$$

Frit Loading: $\quad \underline{\mathrm{z}}_{\mathrm{f}} \underline{\mathrm{a}}_{\mathrm{f}}{ }^{\mathrm{T}} \geq 70$ and $\underline{\mathrm{z}}_{\mathrm{f}} \underline{\mathrm{a}}_{\mathrm{f}}{ }^{\mathrm{T}} \leq 85$

$$
\begin{aligned}
& \underline{\mathrm{z}}_{\mathrm{f}} \equiv\left\lfloor\mathrm{z}_{\mathrm{Cs}_{2} \mathrm{O}}, \mathrm{z}_{\mathrm{Li}_{2} \mathrm{O}}, \mathrm{z}_{\mathrm{K}_{2} \mathrm{O}}, \mathrm{z}_{\mathrm{Na}_{2} \mathrm{O}}, \mathrm{z}_{\mathrm{B}_{2} \mathrm{O}_{3}}, \mathrm{z}_{\mathrm{SiO}_{2}}\right\rfloor \\
& \underline{\mathrm{a}}_{\mathrm{f}} \equiv\left\lfloor\mathrm{M}_{\mathrm{Cs}_{2} \mathrm{O}}, \mathrm{M}_{\mathrm{Li}_{2} \mathrm{O}}, \mathrm{M}_{\mathrm{K}_{2} \mathrm{O}}, \mathrm{M}_{\mathrm{Na}_{2} \mathrm{O}}, \mathrm{M}_{\mathrm{B}_{2} \mathrm{O}_{3}}, \mathrm{M}_{\mathrm{SiO}_{2}}\right\rfloor
\end{aligned}
$$

Using this same notation and transforming each of these constraints into a form similar to that provided in equation (1) yields:

Homogeneity: $\quad \underline{z}_{h}\left(-\underline{a}_{h}{ }^{T}\right)-b_{h} \geq 0$

Alumina: $\quad \mathrm{Z}_{\mathrm{Al}_{2} \mathrm{O}_{3}} \mathrm{M}_{\mathrm{Al}_{2} \mathrm{O}_{3}}-3.0 \geq 0$

Low Frit Loading: $\quad \underline{\mathrm{z}}_{\mathrm{f}} \underline{\mathrm{a}}_{\mathrm{f}}{ }^{\mathrm{T}}-70 \geq 0$

High Frit Loading: $\quad \underline{\mathrm{z}}_{\mathrm{f}}\left(-\underline{\mathrm{a}}_{\mathrm{f}}^{\mathrm{T}}\right)-(-85) \geq 0$

To complete the assessment of these constraints for a given composition requires that the appropriate uncertainties be accounted for in the constraints. Since no propertycomposition models are utilized in meeting the solubility constraints, no property model uncertainty need be applied. This leaves only measurement uncertainty for each of these constraints. And since each of the constraints involves a linear combination of the $\underline{z}$ vector of component concentrations, the measurement uncertainty can be addressed as described in Appendix B.

Thus, letting $\underline{\mathrm{Z}}_{n} \underline{\mathrm{a}}^{\mathrm{T}}$ represent the linear combination of the average molar concentrations (based on $n$ samples) of any one of these constraints and $\beta$ the corresponding offset (see Table 7 for the vectors and offsets that allow these constraints to be placed in the form of equation (1)), then the constraint with measurement uncertainty would be of the form:

$\dagger \dagger$ The terms representing sludge and frit components in the original homogeneity constraint $-c_{\mathrm{S}}$ and $c_{\mathrm{f}}$, respectivelyhave been represented by a single $1 \mathrm{xq}$ array, $\underline{\mathrm{a}} \mathrm{h}$, containing all relevant terms. 


$$
\left[\underline{\mathrm{z}}_{\mathrm{n}} \underline{\mathrm{a}}^{\mathrm{T}}-\beta-\mathrm{t}_{\alpha}(\mathrm{m}-1) \sqrt{\frac{\underline{\mathrm{a}}_{\underline{\mathrm{a}}^{\mathrm{T}}}^{\mathrm{n}}}{\mathrm{n}}} \geq 0\right]
$$

where

$\mathrm{t}_{\alpha}(\mathrm{m}-1)$ represents the upper $100 \alpha \%$ tail of the Student's $t$ distribution with $\mathrm{m}-1$ degrees of freedom and

$$
\frac{\underline{\mathrm{a} S \underline{\mathrm{a}}^{\mathrm{T}}}}{\mathrm{n}} \equiv \operatorname{maximum}\left[\begin{array}{l}
\frac{\left(\underline{\mathrm{a}}_{\mathrm{i}}\right) \mathbf{S}_{\mathrm{m}}\left(\underline{\mathrm{a}}_{\mathrm{i}}\right)^{\mathrm{T}}}{\mathrm{n}}=\frac{1}{\mathrm{n}} \sum_{\mathrm{j}=0}^{\mathrm{q}-1} \sum_{\mathrm{k}=0}^{\mathrm{q}-1}\left(\underline{\mathrm{a}}_{\mathrm{i}}\right)_{\mathrm{j}}\left(\underline{\mathrm{a}}_{\mathrm{i}}\right)_{\mathrm{k}}\left(\mathbf{S}_{\mathrm{m}}\right)_{\mathrm{j}, \mathrm{k}} \\
\frac{\left(\underline{\mathrm{a}}_{\mathrm{i}}\right) \mathbf{S}_{\mathrm{n}}\left(\underline{\mathrm{a}}_{\mathrm{i}}\right)^{\mathrm{T}}}{\mathrm{n}}=\frac{1}{\mathrm{n}} \sum_{\mathrm{j}=0}^{\mathrm{q}-1} \sum_{\mathrm{k}=0}^{\mathrm{q}-1}\left(\underline{\mathrm{a}}_{\mathrm{i}}\right)_{\mathrm{j}}\left(\underline{\mathrm{a}}_{\mathrm{i}}\right)_{\mathrm{k}}\left(\mathbf{S}_{\mathrm{n}}\right)_{\mathrm{j}, \mathrm{k}}
\end{array}\right]
$$

with $S_{m}$ and $S_{n}$ representing the covariance matrices (an absolute based upon historical data versus a relative based upon the current $\underline{\mathrm{z}}$ vector, respectively) as described in Appendix B. 
Table 7. Vectors and Offsets for Homogeneity, Frit Loading, Alumina, and Alkali Constraints

\begin{tabular}{|c|c|c|c|c|c|c|}
\hline & $\mathrm{z}^{\mathrm{T}}$ & & & & & \\
\hline & Average & \multicolumn{5}{|c|}{ Transpose a Vector for Each of the Indicated Constraints } \\
\hline & Molar Oxide & & & & & \\
\hline Oxide & Wt Fraction & $\mathrm{a}^{\mathrm{T}}$ homog & $\mathrm{a}^{\mathrm{T}} \mathrm{Al2O3}$ & $\mathrm{a}^{\mathrm{T}}$ low frit & $\mathrm{a}^{\mathrm{T}}$ high frit & $\mathrm{a}^{\mathrm{T}}$ alkali \\
\hline $\mathrm{Al}_{2} \mathrm{O}_{3}$ & $\mathrm{z}_{\mathrm{A} 12 \mathrm{O} 3}$ & 575.85645 & 101.961 & 0 & 0 & 0 \\
\hline $\mathrm{B}_{2} \mathrm{O}_{3}$ & $\mathrm{Z}_{\mathrm{B} 2 \mathrm{O} 3}$ & 111.63599 & 0 & 69.6202 & -69.6202 & 0 \\
\hline $\mathrm{BaO}$ & $\mathrm{Z}_{\mathrm{BaO}}$ & 0 & 0 & 0 & 0 & 0 \\
\hline $\mathrm{HCOO}$ & $\mathrm{Z}_{\mathrm{HCOO}}$ & 0 & 0 & 0 & 0 & 0 \\
\hline $\mathrm{CaO}$ & $\mathrm{Z}_{\mathrm{CaO}}$ & 316.72525 & 0 & 0 & 0 & 0 \\
\hline $\mathrm{Ce}_{2} \mathrm{O}_{3}$ & $\mathrm{Z}_{\mathrm{Ce} 2 \mathrm{O} 3}$ & 1853.8236 & 0 & 0 & 0 & 0 \\
\hline $\mathrm{NaCl}$ & $\mathrm{Z}_{\mathrm{NaCl}}$ & 0 & 0 & 0 & 0 & 0 \\
\hline $\mathrm{Cr}_{2} \mathrm{O}_{3}$ & $\mathrm{Z}_{\mathrm{Cr} 2 \mathrm{O3}}$ & 0 & 0 & 0 & 0 & 0 \\
\hline $\mathrm{Cs}_{2} \mathrm{O}$ & $\mathrm{Z}_{\mathrm{Cs} 2 \mathrm{O}}$ & 451.88135 & 0 & 281.8094 & -281.8094 & -281.8094 \\
\hline $\mathrm{CuO}$ & $\mathrm{Z}_{\mathrm{CuO}}$ & 0 & 0 & 0 & 0 & 0 \\
\hline $\mathrm{NaF}$ & $\mathrm{Z}_{\mathrm{NaF}}$ & 0 & 0 & 0 & 0 & 0 \\
\hline $\mathrm{Fe}_{2} \mathrm{O}_{3}$ & $\mathrm{Z}_{\mathrm{Fe} 2 \mathrm{O} 3}$ & 901.9096 & 0 & 0 & 0 & 0 \\
\hline $\mathrm{K}_{2} \mathrm{O}$ & $\mathrm{Z}_{\mathrm{K} 2 \mathrm{O}}$ & 151.05515 & 0 & 94.2034 & -94.2034 & -94.2034 \\
\hline $\mathrm{La}_{2} \mathrm{O}_{3}$ & $\mathrm{Z}_{\mathrm{La} 2 \mathrm{O} 3}$ & 1840.156 & 0 & 0 & 0 & 0 \\
\hline $\mathrm{Li}_{2} \mathrm{O}$ & $\mathrm{Z}_{\mathrm{L} \text { i2O }}$ & 47.90841 & 0 & 29.8774 & -29.8774 & -29.8774 \\
\hline $\mathrm{MgO}$ & $\mathrm{Z}_{\mathrm{MgO}}$ & 0 & 0 & 0 & 0 & 0 \\
\hline $\mathrm{MnO}$ & $\mathrm{Z}_{\mathrm{MnO}}$ & 0 & 0 & 0 & 0 & 0 \\
\hline $\mathrm{MoO}_{3}$ & $\mathrm{Z}_{\mathrm{MoO} 3}$ & 812.93414 & 0 & 0 & 0 & 0 \\
\hline $\mathrm{NO}_{2}$ & $\mathrm{Z}_{\mathrm{NO} 2}$ & 0 & 0 & 0 & 0 & 0 \\
\hline $\mathrm{NO}_{3}$ & $\mathrm{Z}_{\mathrm{NO} 3}$ & 0 & 0 & 0 & 0 & 0 \\
\hline $\mathrm{Na}_{2} \mathrm{O}$ & $\mathrm{Z}_{\mathrm{Na} 2 \mathrm{O}}$ & 99.38332 & 0 & 61.979 & -61.979 & -61.979 \\
\hline $\mathrm{Na}_{2} \mathrm{SO}_{4}$ & $\mathrm{Z}_{\mathrm{Na} 2 \mathrm{SO} 4}$ & 0 & 0 & 0 & 0 & 0 \\
\hline $\mathrm{Nd}_{2} \mathrm{O} 3$ & $\mathrm{Z}_{\mathrm{Nd} 2 \mathrm{O} 3}$ & 1900.3616 & 0 & 0 & 0 & 0 \\
\hline $\mathrm{NiO}$ & $\mathrm{Z}_{\mathrm{NiO}}$ & 0 & 0 & 0 & 0 & 0 \\
\hline $\mathrm{P}_{2} \mathrm{O}_{5}$ & $\mathrm{Z}_{\mathrm{P} 2 \mathrm{O} 5}$ & 0 & 0 & 0 & 0 & 0 \\
\hline $\mathrm{PbO}$ & $\mathrm{Z}_{\mathrm{PbO}}$ & 0 & 0 & 0 & 0 & 0 \\
\hline $\mathrm{SiO}_{2}$ & $\mathrm{Z}_{\mathrm{SiO} 2}$ & 96.34598 & 0 & 60.0848 & -60.0848 & 0 \\
\hline $\mathrm{ThO}_{2}$ & $\mathrm{Z}_{\mathrm{ThO} 2}$ & 0 & 0 & 0 & 0 & 0 \\
\hline $\mathrm{TiO}_{2}$ & $\mathrm{Z}_{\mathrm{TiO} 2}$ & 0 & 0 & 0 & 0 & 0 \\
\hline $\mathrm{U}_{3} \mathrm{O}_{8}$ & $Z_{\mathrm{U} 308}$ & 0 & 0 & 0 & 0 & 0 \\
\hline $\mathrm{Y}_{2} \mathrm{O}_{3}$ & $\mathrm{Z}_{\mathrm{Y} 2 \mathrm{O} 3}$ & 1275.3196 & 0 & 0 & 0 & 0 \\
\hline $\mathrm{ZnO}$ & $\mathrm{Z}_{\mathrm{ZnO}}$ & 0 & 0 & 0 & 0 & 0 \\
\hline $\mathrm{ZrO}_{2}$ & $\mathrm{Z}_{\mathrm{ZrO} 2}$ & 0 & 0 & 0 & 0 & 0 \\
\hline & \multirow{2}{*}{ Offset $(\beta)$} & 210.9203 & 3 & 70 & -85 & -19.3 \\
\hline & & $\beta_{\text {homog }}$ & $\beta_{\mathrm{Al} 2 \mathrm{O} 3}$ & $\beta_{\text {low frit }}$ & $\beta_{\text {high frit }}$ & $\beta_{\text {alkali }}$ \\
\hline
\end{tabular}

This approach leads to the following expressions for the MAR associated with each of these constraints.

$\underline{\mathrm{z}}_{\mathrm{n}} \underline{\mathrm{a}}_{\text {homog }}^{\mathrm{T}}-(210.9203)-\mathrm{t}_{\alpha}(\mathrm{m}-1) \sqrt{\frac{\underline{\mathrm{a}}_{\text {homog }} \mathbf{S} \underline{\mathrm{a}}_{\text {homog }}^{\mathrm{T}}}{\mathrm{n}}} \geq 0$ 
$\underline{\mathrm{z}}_{\mathrm{n}} \underline{\mathrm{a}}_{\mathrm{Al}_{2} \mathrm{O}_{3}}^{\mathrm{T}}-3.0-\mathrm{t}_{\alpha}(\mathrm{m}-1) \sqrt{\frac{\underline{\mathrm{a}}_{\mathrm{Al}_{2} \mathrm{O}_{3}} \mathbf{S}_{\underline{\mathrm{a}}_{\mathrm{Al}_{2} \mathrm{O}_{3}}^{\mathrm{T}}}^{\mathrm{n}}}{\mathrm{n}}} \geq 0$

$\underline{\mathrm{z}}_{\mathrm{n}} \underline{\mathrm{a}}_{\text {low frit }}^{\mathrm{T}}-70-\mathrm{t}_{\alpha}(\mathrm{m}-1) \sqrt{\frac{\underline{\mathrm{a}}_{\text {low frit }} \mathbf{S} \underline{\mathrm{a}}_{\text {low frit }}^{\mathrm{T}}}{\mathrm{n}}} \geq 0$

$\underline{\mathrm{z}}_{\mathrm{n}} \underline{\mathrm{a}}_{\text {high frit }}^{\mathrm{T}}-(-85)-\mathrm{t}_{\alpha}(\mathrm{m}-1) \sqrt{\frac{\underline{\mathrm{a}}_{\text {high frit }} \mathbf{S} \underline{\mathrm{a}}_{\text {high frit }}^{\mathrm{T}}}{\mathrm{n}}} \geq 0$

If all of these MAR constraints are satisfied, then $\underline{z}_{n}$ is acceptable for this set of constraints that support the assessment of product quality for the SME batch. However, as discussed in Section 4 and outlined in Table 2, there are some alternatives for meeting the MAR requirements for the homogeneity [4] and low frit [6] constraints.

For homogeneity, if $\underline{\underline{z}}_{n}$ satisfies the homogeneity PAR, i.e. if

$$
\underline{\mathrm{z}}_{\mathrm{n}} \underline{\mathrm{a}}_{\mathrm{h} \text { homog }}^{\mathrm{T}}-(210.9203) \geq 0
$$

then as long as one of the following is true, the homogeneity constraint is satisfied:

Option 1

$\underline{\mathrm{z}}_{\mathrm{n}} \underline{\mathrm{a}}_{\mathrm{Al}_{2} \mathrm{O}_{3}}^{\mathrm{T}}-3.0-\mathrm{t}_{\alpha}(\mathrm{m}-1) \sqrt{\frac{\underline{\mathrm{a}}_{\mathrm{Al}_{2} \mathrm{O}_{3}} \mathbf{S}_{\underline{\mathrm{a}}_{\mathrm{Al}_{2} \mathrm{O}_{3}}^{\mathrm{T}}}^{\mathrm{n}}}{\mathrm{O}}} \geq 0$

and

$$
\underline{\mathrm{z}}_{\mathrm{n}} \underline{\mathrm{a}}_{\text {alkali }}^{\mathrm{T}}-(-19.3)-\mathrm{t}_{\alpha}(\mathrm{m}-1) \sqrt{\frac{\underline{\mathrm{a}}_{\text {alkali }} \mathbf{S} \underline{\mathrm{a}}_{\text {alkali }}^{\mathrm{T}}}{\mathrm{n}}} \geq 0
$$

where the vector and offset associated with the alkali content of the composition are provided in Table 7.

Option 2

$$
\underline{\mathrm{z}}_{\mathrm{n}} \underline{\mathrm{a}}_{\mathrm{Al}_{2} \mathrm{O}_{3}}^{\mathrm{T}}-4.0-\mathrm{t}_{\alpha}(\mathrm{m}-1) \sqrt{\frac{\underline{\mathrm{a}}_{\mathrm{Al}_{2} \mathrm{O}_{3}} \mathbf{S} \underline{\mathrm{a}}_{\mathrm{Al}_{2} \mathrm{O}_{3}}^{\mathrm{T}}}{\mathrm{n}}} \geq 0
$$

The low frit constraint can be omitted from the acceptability decision if the average molar oxide concentration, $\underline{\mathrm{z}}_{\mathrm{n}}$, satisfies the following constraint on alumina:

$$
\underline{\mathrm{z}}_{\mathrm{n}} \underline{\mathrm{a}}_{\mathrm{Al}_{2} \mathrm{O}_{3}}^{\mathrm{T}}-4.43-\mathrm{t}_{\alpha}(\mathrm{m}-1) \sqrt{\frac{\underline{\mathrm{a}}_{\mathrm{Al}_{2} \mathrm{O}_{3}} \mathbf{S}_{\underline{\mathrm{a}}^{\mathrm{T}}}^{\mathrm{T} \mathrm{Al}_{2}}}{\mathrm{n}}} \geq 0
$$


Thus, these are the options for satisfying these constraints that support the assessment of product quality.

\subsubsection{DURABILITY CONSTRAINTS}

Glasses produced in the DWPF melter must have normalized releases for $\mathrm{B}, \mathrm{Li}$, and $\mathrm{Na}$ (as measured by the PCT) less than the corresponding releases for the EA glass. These releases cannot be routinely measured during DWPF operation; they have instead been related to glass composition (which can be measured) using simple regression models of the form [1]:

$$
\log \left[\mathrm{NC}_{\mathrm{i}}\right]=\mathrm{m}_{\mathrm{i}} \Delta \mathrm{G}_{\mathrm{p}}+\mathrm{b}_{\mathrm{i}}
$$

where $\quad \log$ represents the common logarithm, i represents $\mathrm{B}, \mathrm{Li}$, or $\mathrm{Na}$, $\mathrm{NC}_{\mathrm{i}}$ represents the normalized (PCT) release in $\mathrm{g} / \mathrm{L}$ for element $\mathrm{i}$, $\mathrm{m}_{\mathrm{i}}$ is the estimated slope of the simple linear regression for element $\mathrm{i}$, $b_{i}$ is the estimated intercept of the simple linear regression for element $i$, and $\Delta \mathrm{G}_{\mathrm{p}}$ represents the free energy of hydration (in $\mathrm{kcal} / \mathrm{mole}$ ), which is derived from the glass composition.

Table 8 provides the regression information for each of the durability models. The estimated slope and intercept are provided along the root mean square error (RMSE), $s_{i}$, associated with the fitted equation for each element, i. Some information common to all three models is also provided: the sample size, $\mathrm{n}=131$, the number of estimated parameters, $\mathrm{p}=2$, and the $\mathrm{X}^{\prime} \mathrm{X}$ matrix where $\mathrm{X}$ is the vector of values associated with the independent variable, $\Delta \mathrm{G}_{\mathrm{p}}$, which was used in the model fitting process.

Table 8. Regression Information Associated with Fitted Durability Models

\begin{tabular}{|c|c|c|c|c|c|c|c|}
\hline $\mathrm{i}$ & $\mathrm{m}_{\mathrm{i}}$ & $b_{i}$ & RMSE, $s_{i}$ & $n=131$ & \multirow{2}{*}{$\mathrm{X}^{\mathrm{T}} \mathrm{X}=$} & 131 & -1355.2282 \\
\hline B & -0.1812 & -1.9014 & 0.2163 & & & -1355.2282 & 14628.321 \\
\hline $\mathrm{Li}$ & -0.1468 & -1.5459 & 0.1827 & $p=2$ & & & \\
\hline $\mathrm{Na}$ & -0.171 & -1.8012 & 0.1879 & & & & \\
\hline
\end{tabular}

The average normalized release for $\mathrm{EA}$ is $\mathrm{NC}_{\mathrm{B}}=16.7 \mathrm{~g} / \mathrm{L}$ or 1.2227 as a common logarithm. In DWPF, the intention is to control durability by controlling $\Delta \mathrm{G}_{\mathrm{p}}$ by controlling glass composition. The $\Delta \mathrm{G}_{\mathrm{p}}$ corresponding to the average EA boron release from the boron fitted model is:

$$
\frac{\log \left[\mathrm{NC}_{\mathrm{B}}\right]-\mathrm{b}_{\mathrm{B}}}{\mathrm{m}_{\mathrm{B}}}=\Delta \mathrm{G}_{\mathrm{p}} \Rightarrow \frac{1.2227-(-1.9014)}{-0.1812}=\Delta \mathrm{G}_{\mathrm{p}}=-17.2413
$$


However, the $\Delta \mathrm{G}_{\mathrm{p}}$ computed from the measured chemical composition of the EA glass is -15.5186 , which is considerably greater than the value derived from the regression line for boron release. Based upon the durability models (as illustrated in Figure 1), glass compositions with larger values of $\Delta \mathrm{G}_{\mathrm{p}}$ 's are predicted to leach less (to be more durable) than glass compositions with smaller (more negative) $\Delta \mathrm{G}_{\mathrm{p}}$ 's. Therefore, to be conservative, the $\Delta \mathrm{G}_{\mathrm{p}}$ value computed from the measured EA glass composition will be used for the durability composition limit. Furthermore, this $\Delta \mathrm{G}_{\mathrm{p}}$ value bounds all the $\mathrm{B}$, $\mathrm{Li}$, and $\mathrm{Na}$ regression models, and thus, will be used as the composition limit for all three releases.

\subsubsection{EXPECTED PROPERTY ACCEPTANCE REGION (EPAR) FOR DURABILITY}

Using the information provided in Table 8, the "expected" value of $\log \left[\mathrm{NC}_{\mathrm{i}}\right]$ predicted by the boron durability model corresponding to the $\Delta \mathrm{G}_{\mathrm{p}}$ for the EA composition (i.e., $\Delta \mathrm{G}_{\mathrm{EA}}$ $\equiv-15.5186)$ is given by:

$$
\begin{aligned}
\pi_{\mathrm{B}}=\log \left[\mathrm{NC}_{\mathrm{B}}\right]= & \mathrm{m}_{\mathrm{B}} \cdot \Delta \mathrm{G}_{\mathrm{EA}}+\mathrm{b}_{\mathrm{B}}=-0.1812 \cdot \Delta \mathrm{G}_{\mathrm{EA}}-1.9014 \\
& =-0.1812 \cdot(-15.51886)-1.9014=0.9106
\end{aligned}
$$

Similarly, $\pi_{\mathrm{Li}}=0.7322$ and $\pi_{\mathrm{Na}}=0.8525$. Converting these predicted PCT responses to $\mathrm{g} / \mathrm{L}$ by taking the antilogarithm yields $8.139,5.398,7.12 \mathrm{~g} / \mathrm{L}$ for boron, lithium, and sodium, respectively.

Thus, initially (before accounting for any property model or measurement uncertainty), the durability constraints on $\underline{z}_{n}$, the average measured SME composition, take the form:

$$
\mathrm{c}_{\mathrm{d}} \equiv \sum_{\text {major oxid es }} \mathrm{z}_{\text {oxide }} \ddot{\mathrm{A}} \mathrm{G}_{\text {oxide }}=\underline{\mathrm{z}}_{\mathrm{n}} \mathrm{a}_{\text {boron }}^{\mathrm{T}}=\underline{\mathrm{z}}_{\mathrm{n}} \mathrm{a}_{\text {lithium }}^{\mathrm{T}}=\underline{\mathrm{z}}_{\mathrm{n}} \mathrm{a}_{\text {sodium }}^{\mathrm{T}} \geq-15.5186
$$

where the a vectors, which are provided in Table 9, are all identical. Writing these constraints in the standard form previously used gives:

$$
\begin{aligned}
& \underline{\mathrm{z}}_{\mathrm{n}} \underline{\mathrm{a}}_{\text {boron }}^{\mathrm{T}}-(-15.5186) \geq 0 \\
& \underline{\mathrm{z}}_{\mathrm{n}} \underline{\mathrm{a}}_{\text {lithium }}^{\mathrm{T}}-(-15.5186) \geq 0 \\
& \underline{\mathrm{z}}_{\mathrm{n}} \underline{\mathrm{a}}_{\text {sodium }}^{\mathrm{T}}-(-15.5186) \geq 0
\end{aligned}
$$

Notice that the offsets (the $\beta$ 's) for these constraints are the same and that they do not equal any of the offsets of Table 9. The reason for this is that the values of the offsets of Table 9 incorporate the appropriate property model uncertainties, which are discussed next. 
Table 9. Vectors and Offsets for $\mathrm{B}, \mathrm{Li}$, and Na Durability Constraints

\begin{tabular}{|c|c|c|c|c|}
\hline & $\underline{z}^{\mathrm{T}}$ & & & \\
\hline & Average & \multicolumn{3}{|c|}{ Transpose of a Vectors for the Durability Constraints } \\
\hline & Molar Oxide & & & \\
\hline Oxide & Wt Fraction & $\underline{\mathrm{a}}^{\mathrm{T}}$ boron & $\underline{\mathrm{a}}^{\mathrm{T}}$ lithium & $\underline{\mathrm{a}}^{\mathrm{T}}{ }_{\text {sodium }}$ \\
\hline $\mathrm{Al}_{2} \mathrm{O}_{3}$ & $\mathrm{Z}_{\mathrm{A} 12 \mathrm{O} 3}$ & 37.68 & 37.68 & 37.68 \\
\hline $\mathrm{B}_{2} \mathrm{O}_{3}$ & $\mathrm{Z}_{\mathrm{B} 2 \mathrm{O} 3}$ & -10.43 & -10.43 & -10.43 \\
\hline $\mathrm{BaO}$ & $\mathrm{Z}_{\mathrm{BaO}}$ & -23.18 & -23.18 & -23.18 \\
\hline $\mathrm{HCOO}$ & $\mathrm{z}_{\mathrm{HCOO}}$ & 0 & 0 & 0 \\
\hline $\mathrm{CaO}$ & $\mathrm{z}_{\mathrm{CaO}}$ & -13.79 & -13.79 & -13.79 \\
\hline $\mathrm{Ce}_{2} \mathrm{O}_{3}$ & $\mathrm{z}_{\mathrm{Ce} 2 \mathrm{O} 3}$ & -44.99 & -44.99 & -44.99 \\
\hline $\mathrm{NaCl}$ & $\mathrm{Z}_{\mathrm{NaCl}}$ & 0 & 0 & 0 \\
\hline $\mathrm{Cr}_{2} \mathrm{O}_{3}$ & $\mathrm{Z}_{\mathrm{Cr} 2 \mathrm{O} 3}$ & 11.95 & 11.95 & 11.95 \\
\hline $\mathrm{Cs}_{2} \mathrm{O}$ & $\mathrm{Z}_{\mathrm{Cs} 2 \mathrm{O}}$ & -80.38 & -80.38 & -80.38 \\
\hline $\mathrm{CuO}$ & $\mathrm{Z}_{\mathrm{CuO}}$ & -4.954849192 & -4.954849192 & -4.954849192 \\
\hline $\mathrm{NaF}$ & $\mathrm{Z}_{\mathrm{NaF}}$ & 0 & 0 & 0 \\
\hline $\mathrm{Fe}_{2} \mathrm{O}_{3}$ & $\mathrm{Z}_{\mathrm{Fe} 2 \mathrm{O} 3}$ & 14.56 & 14.56 & 14.56 \\
\hline $\mathrm{K}_{2} \mathrm{O}$ & $\mathrm{Z}_{\mathrm{K} 2 \mathrm{O}}$ & -76.41 & -76.41 & -76.41 \\
\hline $\mathrm{La}_{2} \mathrm{O}_{3}$ & $\mathrm{Z}_{\mathrm{La} 2 \mathrm{O3}}$ & -48.59 & -48.59 & -48.59 \\
\hline $\mathrm{Li}_{2} \mathrm{O}$ & $\mathrm{Z}_{\mathrm{Li} 2 \mathrm{O}}$ & -24.04 & -24.04 & -24.04 \\
\hline $\mathrm{MgO}$ & $\mathrm{Z}_{\mathrm{MgO}}$ & -6.57 & -6.57 & -6.57 \\
\hline $\mathrm{MnO}$ & $\mathrm{Z}_{\mathrm{MnO}}$ & -24.44 & -24.44 & -24.44 \\
\hline $\mathrm{MoO}_{3}$ & $\mathrm{Z}_{\mathrm{MoO3}}$ & 16.46 & 16.46 & 16.46 \\
\hline $\mathrm{NO}_{2}$ & $\mathrm{Z}_{\mathrm{NO} 2}$ & 0 & 0 & 0 \\
\hline $\mathrm{NO}_{3}$ & $\mathrm{Z}_{\mathrm{NO} 3}$ & 0 & 0 & 0 \\
\hline $\mathrm{Na}_{2} \mathrm{O}$ & $\mathrm{Z}_{\mathrm{Na} 2 \mathrm{O}}$ & -53.09 & -53.09 & -53.09 \\
\hline $\mathrm{Na}_{2} \mathrm{SO}_{4}$ & $\mathrm{Z}_{\mathrm{Na} 2 \mathrm{SO} 4}$ & 0 & 0 & 0 \\
\hline $\mathrm{Nd}_{2} \mathrm{O} 3$ & $\mathrm{Z}_{\mathrm{Nd} 2 \mathrm{O} 3}$ & -37.79 & -37.79 & -37.79 \\
\hline $\mathrm{NiO}$ & $\mathrm{Z}_{\mathrm{NiO}}$ & 0.37 & 0.37 & 0.37 \\
\hline $\mathrm{P}_{2} \mathrm{O}_{5}$ & $Z_{\mathrm{P} 205}$ & -26.55 & -26.55 & -26.55 \\
\hline $\mathrm{PbO}$ & $\mathrm{Z}_{\mathrm{PbO}}$ & 21.05 & 21.05 & 21.05 \\
\hline $\mathrm{SiO}_{2}$ & $\mathrm{Z}_{\mathrm{SiO} 2}$ & 4.05 & 4.05 & 4.05 \\
\hline $\mathrm{ThO}_{2}$ & $\mathrm{Z}_{\mathrm{ThO} 2}$ & 19.23 & 19.23 & 19.23 \\
\hline $\mathrm{TiO}_{2}$ & $\mathrm{Z}_{\mathrm{TiO} 2}$ & 16.27 & 16.27 & 16.27 \\
\hline $\mathrm{U}_{3} \mathrm{O}_{8}$ & $\mathrm{Z}_{\mathrm{U} 3 \mathrm{O} 8}$ & -23.77 & -23.77 & -23.77 \\
\hline $\mathrm{Y}_{2} \mathrm{O}_{3}$ & $Z_{\mathrm{Y}_{203}}$ & -12.91 & -12.91 & -12.91 \\
\hline $\mathrm{ZnO}$ & $\mathrm{Z}_{\mathrm{ZnO}}$ & 0.92 & 0.92 & 0.92 \\
\hline $\mathrm{ZrO}_{2}$ & $\mathrm{Z}_{\mathrm{ZrO} 2}$ & 17.49 & 17.49 & 17.49 \\
\hline & \multirow[b]{2}{*}{ Offset $(\beta)$} & -12.8833 & -12.7808 & -13.0763 \\
\hline & & $\beta_{\text {boron }}$ & $\beta_{\text {lithium }}$ & $\beta_{\text {sodium }}$ \\
\hline
\end{tabular}

\subsubsection{PROPERTY ACCEPTANCE REGION (PAR) FOR DURABILITY}

As evidenced by low-alumina glasses, PCT releases predicted from the $\Delta \mathrm{G}_{\mathrm{p}}$-based models may be significantly biased. Furthermore, the glasses used to develop this durability model exhibit appreciable scatter in measured PCT responses for narrow ranges of $\Delta \mathrm{G}_{\mathrm{p}}$ - more than would be suggested solely by the PCT methodology [1]. This causes difficulty, since the use of a regression model for durability prediction dictates that 1) the error in $\Delta \mathrm{G}_{\mathrm{p}}$ is negligible relative to that in PCT response (i.e., $\left.\log \left[\mathrm{NC}_{\mathrm{i}}\right]\right)$ and 2) the error in the resulting regression model comes from that in the measured PCT response. The first condition seems reasonable for the model glasses as these were either measured by Corning Engineering Laboratory Services (CELS) or bias 
corrected to CELS standards. However, the fact that the measured PCT responses are more scattered over narrow ranges of $\Delta \mathrm{G}_{\mathrm{p}}$ than would be suggested by the analytical method indicates that additional sources of error may be unaccounted for.

To provide more conservative durability limits to account for departure from straight-line behavior and unaccounted for variances, a one-sided $100\left(1-\alpha_{0}\right) \%$ simultaneous tolerance limit (where $1-\alpha_{0}$ is the coverage fraction) with $100(1-\alpha) \%$ confidence for multiple predictions will be used to define limits for durability. These tolerance limits bound $100\left(1-\alpha_{0}\right) \%$ of all PCT release predictions at a confidence of $100(1-\alpha) \%$ for each and every $G_{p}$ value as opposed to bounding just the mean PCT release for each and every $\Delta \mathrm{G}_{\mathrm{p}}$ value. The new durability limit, $\pi_{\mathrm{i}}$, which is considerably wider than the corresponding confidence band on the mean PCT release, is defined as the upper simultaneous tolerance interval for element $i$ and is given by [14]:

$$
\pi_{\mathrm{i}}=\mathrm{b}_{\mathrm{i}}+\mathrm{m}_{\mathrm{i}}\left(\mathrm{c}^{*}\right)+\mathrm{s}_{\mathrm{i}}\left\{\sqrt{\mathrm{pF} \mathrm{F}_{\alpha}(\mathrm{p}, \mathrm{n}-\mathrm{p})} \sqrt{\underline{\mathrm{c}}_{0}\left(\mathbf{X}^{\mathrm{T}} \mathbf{X}\right)^{-1} \underline{\mathrm{c}}_{0}{ }^{\mathrm{T}}}+\mathrm{z}_{1-\alpha_{0}} \sqrt{\frac{\mathrm{n}-\mathrm{p}}{\chi_{\alpha / 2, \mathrm{n}-\mathrm{p}}^{2}}}\right\}
$$

where

- the required PAR limit for element $\mathrm{i}$ is given by $ð_{i}$, i refers to $\mathrm{B}, \mathrm{Li}$, or $\mathrm{Na}$

- the estimated slope and intercept of the fitted line for element $\mathrm{i}$ are given by $\mathrm{m}_{\mathrm{i}}$ and $b_{i}$, respectively,

- $s_{i}$ is the root mean square error (RMSE) for the fitted equation for element $i$,

- $F_{\alpha}(p, n-p)$ is the $F$ statistic, depending upon $n$ (i.e., the number of data points on which this p-parameter model is based) and the desired significance level as represented by the parameter $\alpha$,

- the inverse product-moment matrix is represented by $\left(\mathbf{X}^{\mathrm{T}} \mathbf{X}\right)^{-1}$ where the product moment matrix contains information describing the data for the independent variable used to generate the regression equation,

- $\underline{\mathrm{c}}_{0}$ is the vector, $\left[\begin{array}{ll}1 & \mathrm{c}_{0}\end{array}\right]$, containing the parameter, $\mathrm{c}^{*}$ (which in this case $\mathrm{c}^{*}=$ $\left.\Delta \mathrm{G}_{\mathrm{p}}(Æ)\right)$ at which the property will be computed.

- $\mathrm{z}_{1-\alpha_{0}}$ represents the one-sided $100\left(1-\alpha_{0}\right) \%$ percentile point from the standard normal distribution representing the $1-\alpha_{0}$ fraction of the predictions to be covered, and

- $\chi_{\alpha / 2, \mathrm{n}-\mathrm{p}}^{2}$ represents the lower (i.e., $\left.\alpha / 2\right)$ percentile point of the $\chi^{2}$ distribution with $(n-p)$ degrees of freedom. 
Let $c_{i, j}$ equal $i, j$ th element of the inverse product-moment matrix, $\mathbf{c}=\left(\mathbf{x}^{\mathrm{T}} \mathbf{x}\right)^{-1}$. Therefore, the appropriate (i.e., upper) one-sided tolerance interval for the predicted release for element $i$ at a given $c^{*}$ would be given by:

$$
\begin{aligned}
& \pi_{\mathrm{i}}=\mathrm{b}_{\mathrm{i}}+\mathrm{m}_{\mathrm{i}}(\mathrm{c} *)+\mathrm{s}_{\mathrm{i}}\left\{\sqrt{\mathrm{pF}(\mathrm{p}, \mathrm{n}-\mathrm{p})} \sqrt{\left[\begin{array}{cc}
1 & \mathrm{c} *
\end{array}\right]\left[\begin{array}{cc}
\mathrm{c}_{0,0} & \mathrm{c}_{0,1} \\
\mathrm{c}_{0,1} & \mathrm{c}_{1,1}
\end{array}\right]\left[\begin{array}{c}
1 \\
\mathrm{c}^{*}
\end{array}\right]}+\mathrm{z}_{1-\alpha_{0}} \sqrt{\frac{\mathrm{n}-\mathrm{p}}{\chi_{\alpha / 2, \mathrm{n}-\mathrm{p}}^{2}}}\right\} \\
& \pi_{\mathrm{i}}=\left(\mathrm{b}_{\mathrm{i}}+\mathrm{s}_{\mathrm{i}} \mathrm{z}_{1-\alpha_{0}} \sqrt{\frac{\mathrm{n}-\mathrm{p}}{\chi_{\alpha / 2, \mathrm{p}-\mathrm{p}}^{2}}}\right)+\mathrm{m}_{\mathrm{i}}(\mathrm{c} *)+\mathrm{s}_{\mathrm{i}} \sqrt{\mathrm{pF}(\mathrm{p}, \mathrm{n}-\mathrm{p})} \sqrt{\mathrm{c}_{1,1}(\mathrm{c} *)^{2}+2 \mathrm{c}_{0,1}\left(\mathrm{c}^{*}\right)+\mathrm{c}_{0,0}}
\end{aligned}
$$

Thus, at a given limit, $\pi_{\mathrm{i}}$, one of the roots, $\mathrm{c}^{*}$, of the following quadratic equation:

$$
\mathrm{A}(\mathrm{c} *)^{2}+\mathrm{B}(\mathrm{c} *)+\mathrm{C}=0
$$

where

$$
\begin{aligned}
& \mathrm{A} \equiv \mathrm{m}_{\mathrm{i}}{ }^{2}-\mathrm{c}_{1,1}\left[\mathrm{ps}_{\mathrm{i}}^{2} \mathrm{~F}_{\alpha}(\mathrm{p}, \mathrm{n}-\mathrm{p})\right] \\
& \mathrm{B} \equiv-2\left\{\mathrm{~m}_{\mathrm{i}}\left(\pi_{\mathrm{i}}-\mathrm{b}_{\mathrm{i}}-\mathrm{s}_{\mathrm{i}} \mathrm{z}_{1-\alpha_{0}} \sqrt{\frac{\mathrm{n}-\mathrm{p}}{\chi_{\alpha / 2, \mathrm{n}-\mathrm{p}}^{2}}}\right)+\mathrm{c}_{0,1}\left[\mathrm{ps}_{\mathrm{i}}^{2} \mathrm{~F}_{\alpha}(\mathrm{p}, \mathrm{n}-\mathrm{p})\right]\right\} \\
& \mathrm{C} \equiv\left(\pi_{\mathrm{i}}-\mathrm{b}_{\mathrm{i}}-\mathrm{s}_{\mathrm{i}} \mathrm{z}_{1-\alpha_{0}} \sqrt{\frac{\mathrm{n}-\mathrm{p}}{\chi_{\alpha / 2, \mathrm{n}-\mathrm{p}}^{2}}}\right)^{2}-\mathrm{c}_{0,0}\left[\mathrm{ps}_{\mathrm{i}}^{2} \mathrm{~F}_{\alpha}(\mathrm{p}, \mathrm{n}-\mathrm{p})\right]
\end{aligned}
$$

provides the necessary tolerance interval. In revision 3 of this report, algorithms were provided for estimating the percentiles of the $\mathrm{z}, \chi^{2}$, and $\mathrm{F}$ statistics used in these determinations. In this revision, these algorithms are not provided and the values for these statistics are taken as those provided in Table 10. Also, provided in Table 10, are the PAR limits for the $\mathrm{B}, \mathrm{Li}$, and $\mathrm{Na}$ durability constraints derived by solving the above equations using the information provided in this section [15]. 
Table 10. Durability Statistics and Predictions where $p=2$ and $m=131$

\begin{tabular}{cc}
\multicolumn{2}{c}{ where $\mathbf{p}=\mathbf{2}$ and $\mathbf{~}=\mathbf{1 3 1}$} \\
\hline$\alpha=\alpha_{0}=0.05$ & $\begin{array}{c}\text { Values Used in and Determined } \\
\text { by the Calculations of this } \\
\text { Section }\end{array}$ \\
\hline $\mathrm{z}_{1-\alpha_{0}}$ & 1.6449 \\
$\chi_{\alpha / 2, \mathrm{n}-\mathrm{p}}^{2}$ & 99.4532 \\
$\mathrm{z}_{1-\alpha_{0}} \sqrt{\frac{\mathrm{n}-\mathrm{p}}{\chi_{\alpha / 2, \mathrm{n}-\mathrm{p}}^{2}}}$ & 1.8773 \\
$\mathrm{~F}_{\alpha}(\mathrm{p}, \mathrm{n}-\mathrm{p})$ & 3.0664 \\
\hline $\mathrm{B} \Delta \mathrm{G}_{\mathrm{p}} @ \mathrm{PAR}$ & $-12.8833 \mathrm{kcal} / \mathrm{mole}$ \\
$\mathrm{NL}(\mathrm{B}) @ \mathrm{PAR}$ & $2.711 \mathrm{~g} / \mathrm{L}$ \\
\hline $\mathrm{Li} \Delta \mathrm{G}_{\mathrm{p}} @ \mathrm{PAR}$ & $-12.7808 \mathrm{kcal} / \mathrm{mole}$ \\
$\mathrm{NL}(\mathrm{Li}) @ \mathrm{PAR}$ & $2.140 \mathrm{~g} / \mathrm{L}$ \\
\hline $\mathrm{Na} \Delta \mathrm{G}_{\mathrm{p}} @ \mathrm{PAR}$ & $-13.0763 \mathrm{kcal} / \mathrm{mole}$ \\
$\mathrm{NL}(\mathrm{Na}) @ \mathrm{PAR}$ & $2.722 \mathrm{~g} / \mathrm{L}$ \\
\hline
\end{tabular}

These PAR limits for PCT B, Li, and Na releases, $\mathrm{c}_{\mathrm{d}}{ }^{*}$, account not only for the desired property bounds (as represented by $c_{d}{ }^{*}+\mathrm{Gp}(Æ)$ ) but also for the random uncertainty and biases inhering to the predictions. The constraint definition as well as the manner in which the new durability constraints are transformed into constraints on composition is illustrated in Figure 2.

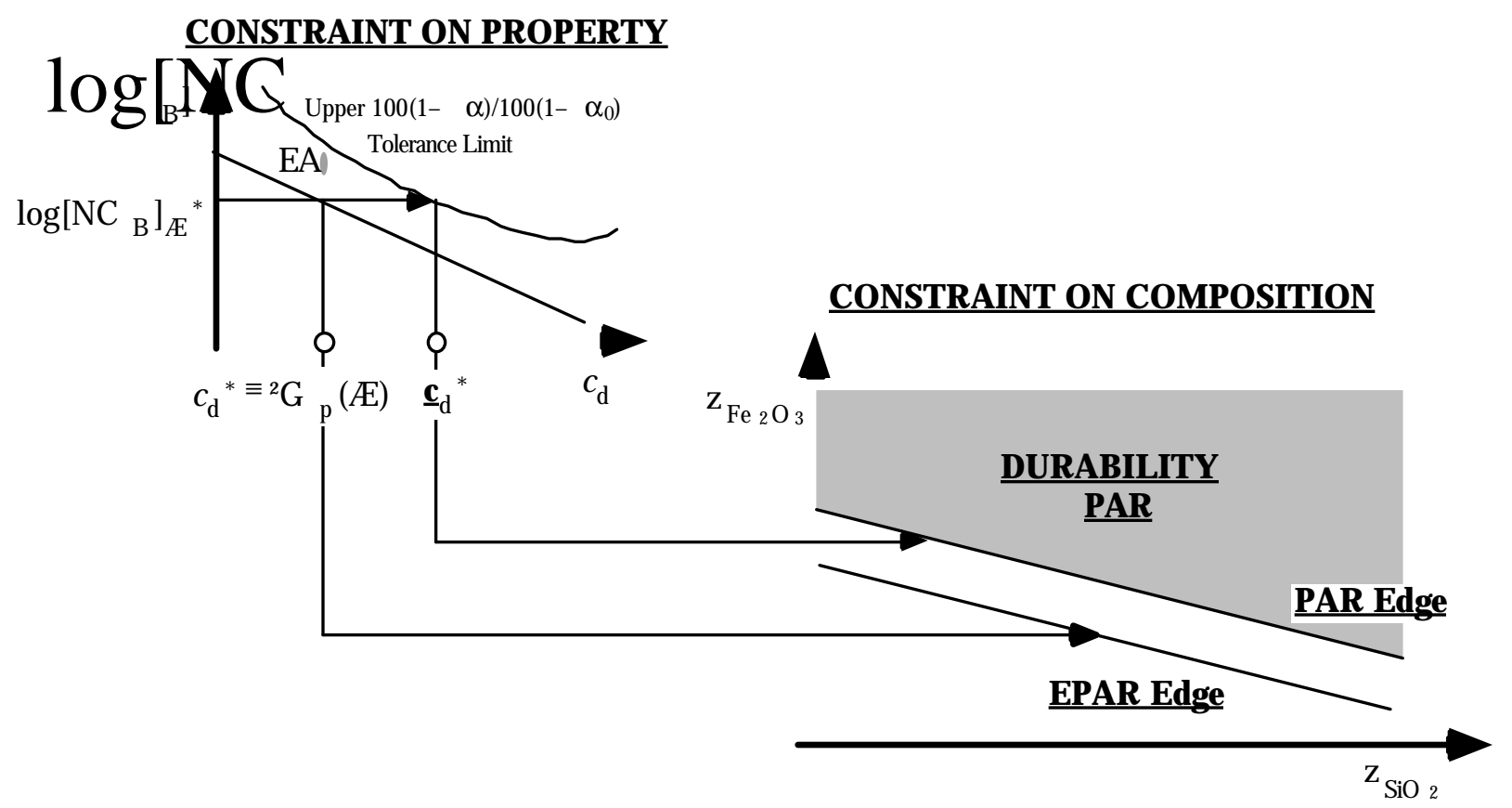

Figure 2. The Boron Durability PAR Definition using Tolerance Intervals 
The $\Delta \mathrm{G}_{\mathrm{p}}$ values for $\mathrm{B}, \mathrm{Li}$, and $\mathrm{Na}$ in Table 10 define the PAR limits, and thus, the offsets, for their corresponding durability constraints. Therefore, these are the values that appear at the bottom of Table 9 .

\subsubsection{MEASUREMENT ACCEPTANCE REgION (MAR) FOR DURABILITY}

To complete the assessment of these constraints for a given composition requires that the measurement uncertainties be accounted for in the constraints. Since each of the durability constraints involves a linear combination of the $\underline{z}$ vector of component concentrations, the measurement uncertainty can be addressed as described in Appendix B.

Thus, letting $\underline{\mathrm{Z}}_{n} \underline{\mathrm{a}}^{\mathrm{T}}$ represent the linear combination of the average molar concentrations (based on $n$ samples) of any one of these constraints and $\beta$ the corresponding offset (see Table 9), then the constraint with measurement uncertainty would be of the form:

$$
\left[\underline{\mathrm{z}}_{\mathrm{n}} \underline{\mathrm{a}}^{\mathrm{T}}-\beta-\mathrm{t}_{\alpha}(\mathrm{m}-1) \sqrt{\frac{\underline{\mathrm{a}}_{\underline{\mathrm{a}}^{\mathrm{T}}}^{\mathrm{n}}}{\mathrm{n}}} \geq 0\right]
$$

where

$t_{\alpha}(m-1)$ represents the upper $100 \alpha \%$ tail of the Student's $t$ distribution with $m-1$ degrees of freedom and

$$
\frac{\underline{\mathrm{a} S \underline{\mathrm{a}}^{\mathrm{T}}}}{\mathrm{n}} \equiv \operatorname{maximum}\left[\begin{array}{l}
\frac{\left(\underline{\mathrm{a}}_{\mathrm{i}}\right) \mathbf{S}_{\mathrm{m}}\left(\underline{\mathrm{a}}_{\mathrm{i}}\right)^{\mathrm{T}}}{\mathrm{n}}=\frac{1}{\mathrm{n}} \sum_{\mathrm{j}=0}^{\mathrm{q}-1} \sum_{\mathrm{k}=0}^{\mathrm{q}-1}\left(\underline{\mathrm{a}}_{\mathrm{i}}\right)_{\mathrm{j}}\left(\underline{\mathrm{a}}_{\mathrm{i}}\right)_{\mathrm{k}}\left(\mathbf{S}_{\mathrm{m}}\right)_{\mathrm{j}, \mathrm{k}} \\
\frac{\left(\underline{\mathrm{a}}_{\mathrm{i}}\right) \mathbf{S}_{\mathrm{n}}\left(\underline{\mathrm{a}}_{\mathrm{i}}\right)^{\mathrm{T}}}{\mathrm{n}}=\frac{1}{\mathrm{n}} \sum_{\mathrm{j}=0}^{\mathrm{q}-1} \sum_{\mathrm{k}=0}^{\mathrm{q}-1}\left(\underline{\mathrm{a}}_{\mathrm{i}}\right)_{\mathrm{j}}\left(\underline{\mathrm{a}}_{\mathrm{i}}\right)_{\mathrm{k}}\left(\mathbf{S}_{\mathrm{n}}\right)_{\mathrm{j}, \mathrm{k}}
\end{array}\right]
$$

with $S_{m}$ and $S_{n}$ representing the covariance matrices (an absolute based upon historical data versus a relative based upon the current $\underline{z}$ vector, respectively) as described in Appendix B..

This approach leads to the following expressions for the MAR associated with each of these durability constraints.

$$
\begin{aligned}
& \underline{\mathrm{z}}_{\mathrm{n}} \underline{\mathrm{a}}_{\text {boron }}^{\mathrm{T}}-(-12.8833)-\mathrm{t}_{\alpha}(\mathrm{m}-1) \sqrt{\frac{\underline{\mathrm{a}}_{\text {boron }} \mathbf{S} \underline{\mathrm{a}}_{\text {boron }}^{\mathrm{T}}}{\mathrm{n}}} \geq 0 \\
& \underline{\mathrm{z}}_{\mathrm{n}} \underline{\mathrm{a}}_{\text {lithium }}^{\mathrm{T}}-(-12.7808)-\mathrm{t}_{\alpha}(\mathrm{m}-1) \sqrt{\frac{\underline{\mathrm{a}}_{\text {lithium }} \mathbf{S} \underline{\mathrm{a}}_{\text {lithium }}^{\mathrm{T}}}{\mathrm{n}}} \geq 0
\end{aligned}
$$


$\underline{\mathrm{z}}_{\mathrm{n}} \underline{\mathrm{a}}_{\text {sodium }}^{\mathrm{T}}-(-13.0763)-\mathrm{t}_{\alpha}(\mathrm{m}-1) \sqrt{\frac{\underline{\mathrm{a}}_{\text {sodium }} \mathbf{S} \underline{\mathrm{a}}_{\text {sodium }}^{\mathrm{T}}}{\mathrm{n}}} \geq 0$

If all of these MAR constraints are satisfied, then $\underline{z}_{n}$ is acceptable for this set of constraints that support the assessment of product quality for the SME batch.

\subsection{Viscosity CONSTRAINTS}

A processing characteristic that is critical during DWPF melter operation is the viscosity of the melt. Once again, there is no opportunity for an in situ measurement of viscosity during processing; this melt property is predicted from the chemical composition of the SME material. The viscosity-composition model $[16,17]$ may be written as:

Viscosity: $:^{\dagger \dagger} \log \eta=\mathrm{m}_{\mathrm{v}} C_{\mathrm{v}}+\mathrm{b}_{\mathrm{v}}$

where

$\eta$ is viscosity in Poise,

$m_{v}$ is the estimated slope for this regression model $\left(m_{v}=-1.5342\right)$

$b_{v}$ is the estimated intercept $\left(b_{v}=3.2788\right)$,

$$
\mathrm{c}_{\mathrm{v}} \equiv \frac{2\left(\mathrm{z}_{\mathrm{Fe}_{2} \mathrm{O}_{3}}-\mathrm{z}_{\mathrm{Al}_{2} \mathrm{O}_{3}}+\mathrm{z}_{\mathrm{Cs}_{2} \mathrm{O}}+\mathrm{z}_{\mathrm{Li}_{2} \mathrm{O}}+\mathrm{z}_{\mathrm{K}_{2} \mathrm{O}}+\mathrm{z}_{\mathrm{Na}_{2} \mathrm{O}}\right)+\mathrm{z}_{\mathrm{B}_{2} \mathrm{O}_{3}}}{\mathrm{z}_{\mathrm{SiO}_{2}}} \text {, and }
$$

$\mathrm{Z}_{\text {oxide }}$ represents the indicated molar oxide concentration in the glass.

This model can be back-solved to translate the viscosity constraints into constraints on the compositional term, $\mathrm{c}_{\mathrm{v}}$, as given by:

High Viscosity:

$$
\text { high viscosity } \equiv \eta_{\mathrm{hv}} \leq 110 \text { poise } \quad \Rightarrow \quad \mathrm{c}_{\mathrm{hv}} \geq\left[\frac{\log \left(\mathrm{c}_{\mathrm{hv}}\right)-\mathrm{b}_{\mathrm{v}}}{\mathrm{m}_{\mathrm{v}}}\right]
$$

$\dagger$ Actually the viscosity prediction is a three-parameter model including an inverse temperature term [6,10]. However, this temperature is fixed at $1150^{\circ} \mathrm{C}$ for DWPF. This allows the viscosity model to be presented as a twoparameter model with the temperature-dependent term included in the pseudo-constant, $\mathrm{b}_{\mathrm{v}}$. 
Low Viscosity:

$$
\text { low viscosity } \equiv \eta_{\mathrm{lv}} \geq 20 \text { poise } \quad \Rightarrow \quad c_{\mathrm{lv}} \leq\left[\frac{\log \left(\mathrm{c}_{\mathrm{lv}}\right)-\mathrm{b}_{\mathrm{v}}}{\mathrm{m}_{\mathrm{v}}}\right]=
$$

The above inequalities describe the region in compositional space where all of the predicted values for viscosity are acceptable. This defines the EPAR for viscosity. The region is denoted as "expected" since it is derived from the fitted line, which is the expected viscosity, based upon the model for a given composition.

\subsubsection{Property ACCEPTANCE Region For Viscosity}

The determination of the viscosity property acceptance region is accomplished by accounting for the property model uncertainty in the implementation of the viscosity constraints. As in the case for durability, statistical confidence intervals are used in the determinations of this uncertainty. However, the confidence intervals used for viscosity differ from those used for the durability models. Since viscosity is non-waste-affecting, the conservatism introduced by the approach used for the durability PAR is not deemed necessary for the viscosity PAR. Specifically, instead of simultaneous tolerance intervals as was used for durability, Scheffé simultaneous confidence limits (also called confidence bands $[18,19])$, are used for the viscosity constraints.

The property models for durability require fitting two parameters, i.e., a slope, $\mathrm{m}$, based upon a term derived from composition and an intercept, b. The viscosity relationship, however, has an additional linear parameter based upon the inverse temperature $(1 / \mathrm{T})$ at which the viscosity $(\eta)$ is measured. This relationship is of the form $[16,17]$ :

$$
\log (\eta)=m_{v} c_{v}+m_{1 / T} \frac{1}{T\left({ }^{\circ} \mathrm{C}\right)}+b
$$

As already indicated in an earlier footnote, for DWPF use, the temperature is fixed at $1150^{\circ} \mathrm{C}$. Thus, the predicting relationship for the viscosity can be written as:

$$
\log (\eta)=m_{v} c_{v}+b_{v} \quad \text { where } b_{v} \equiv \frac{m_{1 / T}}{T\left({ }^{\circ} \mathrm{C}\right)}+b \text { and } \mathrm{T}\left({ }^{\circ} \mathrm{C}\right) \text { is } 1150
$$

However, the additional parameter must be accommodated when defining the confidence limits for viscosity prediction.

In revision 3 of this report, the approach used to develop the viscosity PAR was a conservative one that depended on two-sided, 100(1- $\alpha) \%$ Scheffé-type confidence bands. Since each of the viscosity constraints is considered individually, the confidence level provided by this approach for each constraint is actually $100(1-\alpha / 2) \%$. This extra conservatism is no longer deemed necessary and the true one-sided, 100(1- $\alpha) \%$ Scheffétype confidence limit is to be used to determine the viscosity PAR in this report. The 
appropriate one-sided confidence interval for the predicted melt viscosity would be given by:

$$
\pi=b+m\left(c^{*}\right)+\left(\frac{m_{T}}{T^{*}}\right)+s_{r}\left\{\sqrt{p_{2 \alpha}(p, n-p)} \sqrt{\left[\begin{array}{lll}
1 & c^{*} & \frac{1}{T^{*}}
\end{array}\right]\left[\begin{array}{ccc}
c_{0,0} & c_{0,1} & c_{0,2} \\
c_{0,1} & c_{1,1} & c_{1,2} \\
c_{0,2} & c_{1,2} & c_{2,2}
\end{array}\right]\left[\begin{array}{c}
1 \\
c^{*} \\
\frac{1}{T^{*}}
\end{array}\right]}\right\}
$$

where $\mathrm{T}^{*}=1150^{\circ} \mathrm{C}$. where

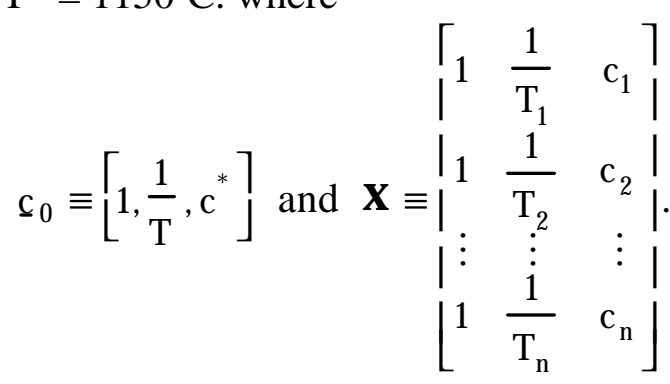

Again the $\mathbf{X}$ matrix contains the data for the independent variables from which the regression model was formulated. The parameter $\mathrm{p}$ represents the number of parameters in the model (i.e., $\mathrm{p}=3$ ) and the product moment matrix, $\left(\mathbf{x}^{\mathrm{T}} \mathbf{x}\right)$, is now of dimension $3 \times 3$ for viscosity prediction. Since the (1/T) term will be constant for DWPF use, the expression can be expanded for each viscosity constraint (i.e., low and high) to a quadratic in $\mathrm{c}^{*}$ given by $\mathrm{A}\left(\mathrm{c}^{*}\right)^{2}+\mathrm{B}\left(\mathrm{c}^{*}\right)+\mathrm{C}=0$ with coefficients:

$$
\begin{aligned}
& \mathrm{A} \equiv \mathrm{m}^{2}-\mathrm{c}_{2,2}\left[\mathrm{ps}_{\mathrm{r}}^{2} \mathrm{~F}_{2 \alpha}(\mathrm{p}, \mathrm{n}-\mathrm{p})\right] \\
& \left.\mathrm{B} \equiv-2\left\{\mathrm{~m}\left(\pi-\mathrm{b}_{\mathrm{T}}\right)+\left(\mathrm{c}_{0,2}+\frac{\mathrm{c}_{1,2}}{\mathrm{~T}^{*}}\right) \mathrm{ps}_{\mathrm{r}}^{2} \mathrm{~F}_{2 \alpha}(\mathrm{p}, \mathrm{n}-\mathrm{p})\right]\right\} \\
& \mathrm{C} \equiv\left(\pi-\mathrm{b}_{\mathrm{T}}\right)^{2}-\left[\mathrm{c}_{0,0}+2\left(\frac{\mathrm{c}_{0,1}}{\mathrm{~T} *}\right)+\frac{\mathrm{c}_{1,1}}{(\mathrm{~T} *)^{2}}\right]\left[\mathrm{ps}_{\mathrm{r}}^{2} \mathrm{~F}_{2 \alpha}(\mathrm{p}, \mathrm{n}-\mathrm{p})\right]
\end{aligned}
$$

The formulas for these coefficients are the same as those utilized in revision 3 of this report except for $2 \alpha$ being substituted for $\alpha$ in estimating the percentiles from the Fdistribution. The reasonable root from this quadratic then supplies the constraint for viscosity prediction. The information from fitting of the viscosity model that is necessary to address property uncertainty is provided in Exhibit 1. 


\section{Exhibit 1. Information Generated from the Fitting of the Viscosity Model}

$$
\begin{aligned}
& \mathrm{p}=3, \mathrm{n}=213, \alpha=0.05, \mathrm{~m}=-1.5342, \mathrm{~b}_{\mathrm{T}}=3.2788^{\dagger}, \mathrm{s}_{\mathrm{r}}=0.07364, \text { and } \\
& \left(\mathbf{X}^{\mathrm{T}} \mathbf{X}\right)=\left[\begin{array}{ccc}
213 & 0.1879 & 207.758 \\
0.1879 & 0.0001679 & 0.1846 \\
207.758 & 0.1846 & 211.9504
\end{array}\right]
\end{aligned}
$$

For the low viscosity constraint, the only parameter that changes in the set of equations for $\mathrm{A}, \mathrm{B}$, and $\mathrm{C}$ is the property limit (i.e., $\left.\pi=\log _{10}(20)=1.30103\right)$. Solving for the roots from the quadratic expression when the more accurate percentile from the F-distribution is used and selecting the desired root corresponding to the appropriate one-sided simultaneous confidence interval yield 1.2739 as the limit in composition space for the viscosity model $[8,15]$, or

$$
\eta=10^{m_{v} c_{v}+b_{v}}=10^{-1.5342 \cdot 1.2739+3.2788}=10^{1.32438}=21.10
$$

(i.e., 21.10 poise at $\mathrm{T}^{*}=1150^{\circ} \mathrm{C}$ ). Only the $\mathrm{SiO}_{2}$ coefficient in the low viscosity constraint is impacted; that is, the $\mathrm{SiO}_{2}$ coefficient in the lower viscosity constraint vector is the root from the quadratic expression, or $\underline{\mathrm{a}}_{\text {low vis, }, \mathrm{SiO}_{2}}=1.2739$, while the coefficients of the other oxides are directly determined from the viscosity model. The complete $\underline{\mathrm{a}}_{\text {low visc }}$ vector is provided in Table 11 .

The upper viscosity limit in this revision has been set to 110 poise as previously discussed; and $\log _{10}(110)$ is used for the value of $\pi$ in solving for the roots of the set of equations for $\mathrm{A}, \mathrm{B}$, and $\mathrm{C}$ for this constraint. When the more accurate percentile from the F-distribution is used, the desired root corresponding to the appropriate one-sided simultaneous confidence interval $[8,15]$ becomes 0.8170 , or

$$
\eta=10^{m_{v} c_{v}+b_{v}}=10^{-1.5342 \cdot 0.8170+3.2788}=10^{2.0254}=106.03
$$

(i.e., 106.03 poise at $\mathrm{T}^{*}=1150^{\circ} \mathrm{C}$ ). Once again, only the $\mathrm{SiO}_{2}$ coefficient in the high viscosity constraint is impacted; that is, the $\mathrm{SiO}_{2}$ coefficient in the high viscosity constraint vector is the root from the quadratic expression, or $\underline{a}_{\text {high visc, } \mathrm{SiO}_{2}}=0.8170$, while the coefficients of the other oxides are directly determined from the viscosity model. The complete $\underline{\mathrm{a}}_{\text {high visc }}$ vector is provided in Table 11 .

The melt viscosity model used is a three parameter model where the melt temperature is assumed to be $1150^{\circ} \mathrm{C}$, and thus the intercept provided is $\mathrm{b}_{\mathrm{T}}=\mathrm{b}+\left(\mathrm{m}_{\mathrm{T}} / 1150\right)=-0.6103+(4472.4452 / 1150)=3.2788$. 
The two constraints for viscosity can be expressed using the notation developed earlier and the vectors provided Table 11. Note that the offsets for the two constraints are zero.

Low Viscosity: $\quad \underline{\mathrm{z}}_{\mathrm{n}} \underline{\mathrm{a}}_{\text {low visc }} \geq 0 \quad \underline{\text { High Viscosity: }} \quad \underline{\mathrm{z}}_{\mathrm{n}} \underline{\mathrm{a}}_{\text {high visc }} \geq 0$

Table 11. Vectors and Offsets for Viscosity Constraints

\begin{tabular}{|c|c|c|c|}
\hline & $\underline{z}^{\mathrm{T}}$ & \multirow{2}{*}{\multicolumn{2}{|c|}{$\begin{array}{l}\text { Transpose of a Vectors } \\
\text { for Viscosity Constraints }\end{array}$}} \\
\hline & \multirow{2}{*}{\begin{tabular}{|r|} 
Average \\
Molar Oxide
\end{tabular}} & & \\
\hline & & & \\
\hline Oxide & Wt Fraction & $\underline{\underline{\mathrm{a}}}_{\text {low visc }}^{\mathrm{T}}$ & $\underline{\underline{a}}^{\mathrm{T}}{ }_{\text {high visc }}$ \\
\hline $\mathrm{Al}_{2} \mathrm{O}_{3}$ & $\mathrm{z}_{\mathrm{Al} 2 \mathrm{O} 3}$ & -2 & 2 \\
\hline $\mathrm{B}_{2} \mathrm{O}_{3}$ & $\mathrm{Z}_{\mathrm{B} 2 \mathrm{O} 3}$ & 1 & -1 \\
\hline $\mathrm{BaO}$ & $\mathrm{z}_{\mathrm{BaO}}$ & 0 & 0 \\
\hline $\mathrm{HCOO}$ & $\mathrm{Z}_{\mathrm{HCOO}}$ & 0 & 0 \\
\hline $\mathrm{CaO}$ & $\mathrm{z}_{\mathrm{CaO}}$ & 0 & 0 \\
\hline $\mathrm{Ce}_{2} \mathrm{O}_{3}$ & $\mathrm{z}_{\mathrm{Ce} 2 \mathrm{O} 3}$ & 0 & 0 \\
\hline $\mathrm{NaCl}$ & $\mathrm{Z}_{\mathrm{NaCl}}$ & 0 & 0 \\
\hline $\mathrm{Cr}_{2} \mathrm{O}_{3}$ & $\overline{\mathrm{Z}_{\mathrm{Cr} 2 \mathrm{O} 3}}$ & 0 & 0 \\
\hline $\mathrm{Cs}_{2} \mathrm{O}$ & $\mathrm{Z}_{\mathrm{Cs} 2 \mathrm{O}}$ & 2 & -2 \\
\hline $\mathrm{CuO}$ & $\mathrm{Z}_{\mathrm{CuO}}$ & 0 & 0 \\
\hline $\mathrm{NaF}$ & $\mathrm{Z}_{\mathrm{NaF}}$ & 0 & 0 \\
\hline $\mathrm{Fe}_{2} \mathrm{O}_{3}$ & $\mathrm{Z}_{\mathrm{Fe} 2 \mathrm{O} 3}$ & 2 & -2 \\
\hline $\mathrm{K}_{2} \mathrm{O}$ & $\mathrm{Z}_{\mathrm{K} 2 \mathrm{O}}$ & 2 & -2 \\
\hline $\mathrm{La}_{2} \mathrm{O}_{3}$ & $\mathrm{Z}_{\mathrm{La} 2 \mathrm{O} 3}$ & 0 & 0 \\
\hline $\mathrm{Li}_{2} \mathrm{O}$ & $\mathrm{Z}_{\mathrm{Li} 2 \mathrm{O}}$ & 2 & -2 \\
\hline $\mathrm{MgO}$ & $\mathrm{Z}_{\mathrm{MgO}}$ & 0 & 0 \\
\hline $\mathrm{MnO}$ & $\mathrm{Z}_{\mathrm{MnO}}$ & 0 & 0 \\
\hline $\mathrm{MoO}_{3}$ & $\mathrm{Z}_{\mathrm{MoO} 3}$ & 0 & 0 \\
\hline $\mathrm{NO}_{2}$ & $\mathrm{Z}_{\mathrm{NO} 2}$ & 0 & 0 \\
\hline $\mathrm{NO}_{3}$ & $\mathrm{Z}_{\mathrm{NO} 3}$ & 0 & 0 \\
\hline $\mathrm{Na}_{2} \mathrm{O}$ & $\mathrm{Z}_{\mathrm{Na} 2 \mathrm{O}}$ & 2 & -2 \\
\hline $\mathrm{Na}_{2} \mathrm{SO}_{4}$ & $\mathrm{Z}_{\mathrm{Na} 2 \mathrm{SO} 4}$ & 0 & 0 \\
\hline $\mathrm{Nd}_{2} \mathrm{O} 3$ & $\mathrm{Z}_{\mathrm{Nd} 2 \mathrm{O} 3}$ & 0 & 0 \\
\hline $\mathrm{NiO}$ & $\mathrm{Z}_{\mathrm{NiO}}$ & 0 & 0 \\
\hline $\mathrm{P}_{2} \mathrm{O}_{5}$ & $\mathrm{Z}_{\mathrm{P} 205}$ & 0 & 0 \\
\hline $\mathrm{PbO}$ & $\mathrm{Z}_{\mathrm{PbO}}$ & 0 & 0 \\
\hline $\mathrm{SiO}_{2}$ & $\mathrm{Z}_{\mathrm{SiO} 2}$ & -0.8170 & 1.2739 \\
\hline $\mathrm{ThO}_{2}$ & $\mathrm{Z}_{\mathrm{ThO} 2}$ & 0 & 0 \\
\hline $\mathrm{TiO}_{2}$ & $\mathrm{Z}_{\mathrm{TiO} 2}$ & 0 & 0 \\
\hline $\mathrm{U}_{3} \mathrm{O}_{8}$ & $\mathrm{Z}_{\mathrm{U} 308}$ & 0 & 0 \\
\hline $\mathrm{Y}_{2} \mathrm{O}_{3}$ & $\mathrm{Z}_{\mathrm{Y} 2 \mathrm{O} 3}$ & 0 & 0 \\
\hline $\mathrm{ZnO}$ & $\mathrm{Z}_{\mathrm{ZnO}}$ & 0 & 0 \\
\hline $\mathrm{ZrO}_{2}$ & $\mathrm{Z}_{\mathrm{ZrO2}}$ & 0 & 0 \\
\hline & Offset $(\beta)$ & 0 & 0 \\
\hline & & $\beta_{\text {low visc }}$ & $\beta_{\text {high visc }}$ \\
\hline
\end{tabular}




\subsubsection{Measurement ACCEPTANCE Region FOR VisCOSITY}

To complete the assessment of these constraints for a given composition requires that the measurement uncertainty for each of these constraints be accounted for. And since each of the viscosity constraints involves a linear combination of the $\underline{z}$ vector of component concentrations, the measurement uncertainty can be addressed as described in Appendix A.

Thus, letting $\underline{Z}_{n} \underline{a}^{T}$ represent the linear combination of the average molar concentrations (based on $n$ samples) of any one of these constraints and noting that the offsets (the $\beta$ 's) are zero for both constraints, then the constraint with measurement uncertainty would be of the form:

$$
\left[\underline{\mathrm{z}}_{\mathrm{n}} \underline{\mathrm{a}}^{\mathrm{T}}-\mathrm{t}_{\alpha}(\mathrm{m}-1) \sqrt{\frac{\underline{\mathrm{a}}^{\mathrm{S}} \underline{\mathrm{a}}^{\mathrm{T}}}{\mathrm{n}}} \geq 0\right],
$$

where

$\mathrm{t}_{\alpha}(\mathrm{m}-1)$ represents the upper $100 \alpha \%$ tail of the Student's $\mathrm{t}$ distribution with $\mathrm{m}-1$ degrees of freedom and

$$
\frac{\underline{\mathrm{a} S} \underline{\underline{a}}^{\mathrm{T}}}{\mathrm{n}} \equiv \max \operatorname{imum}\left[\begin{array}{l}
\left.\frac{\left(\underline{\mathrm{a}}_{\mathrm{i}}\right) \mathbf{S}_{\mathrm{m}}\left(\underline{\mathrm{a}}_{\mathrm{i}}\right)^{\mathrm{T}}}{\mathrm{n}}=\frac{1}{\mathrm{n}} \sum_{\mathrm{j}=0}^{\mathrm{q}-1} \sum_{\mathrm{k}=0}^{\mathrm{q}-1} \underline{\mathrm{a}}_{\mathrm{i}}\right)_{\mathrm{j}}\left(\underline{\mathrm{a}}_{\mathrm{i}}\right)_{\mathrm{k}}\left(\mathbf{S}_{\mathrm{m}}\right)_{\mathrm{j}, \mathrm{k}} \\
\frac{\left(\underline{\mathrm{a}}_{\mathrm{i}}\right) \mathbf{S}_{\mathrm{n}}\left(\underline{\mathrm{a}}_{\mathrm{i}}\right)^{\mathrm{T}}}{\mathrm{n}}=\frac{1}{\mathrm{q}} \sum_{\mathrm{j}=0}^{\mathrm{q}-1} \sum_{\mathrm{k}=0}^{\mathrm{q}-1}\left(\underline{\mathrm{a}}_{\mathrm{i}}\right)_{\mathrm{j}}\left(\underline{\mathrm{a}}_{\mathrm{i}}\right)_{\mathrm{k}}\left(\mathbf{S}_{\mathrm{n}}\right)_{\mathrm{j}, \mathrm{k}}
\end{array}\right]
$$

with $S_{m}$ and $S_{n}$ representing the covariance matrices (an absolute based upon historical data versus a relative based upon the current $\underline{z}$ vector, respectively) as described in Appendix B.

This approach leads to the following expressions for the MAR associated with each of the viscosity constraints.

$$
\begin{aligned}
& \underline{\mathrm{z}}_{\mathrm{n}} \underline{\mathrm{a}}_{\text {low visc }}^{\mathrm{T}}-\mathrm{t}_{\alpha}(\mathrm{m}-1) \sqrt{\frac{\underline{\mathrm{a}}_{\text {low vsic }} \mathbf{S} \underline{\mathrm{a}}_{\text {low visc }}^{\mathrm{T}}}{\mathrm{n}}} \geq 0 \\
& \underline{\mathrm{z}}_{\mathrm{n}} \underline{\mathrm{a}}_{\text {high visc }}^{\mathrm{T}}-\mathrm{t}_{\alpha}(\mathrm{m}-1) \sqrt{\frac{\frac{\mathrm{a}_{\text {high visc }} \mathbf{S} \underline{\mathrm{a}}_{\text {high visc }}^{\mathrm{T}}}{\mathrm{n}}}{2}} \geq 0
\end{aligned}
$$


If this pair of MAR constraints is satisfied, then the SME composition, $\underline{z}_{n}$, is acceptable for each of the viscosity constraints at the $(1-\alpha) 100 \%$ confidence level. Note that the nominal $95 \%$ confidence level (equal to $100[1-\alpha] \%$ ) for these constraints can be adjusted based upon management discretion.

\subsection{LiQuidus Temperature $\left(\mathbf{T}_{\mathrm{L}}\right)$ CONSTRainT}

The liquidus temperature $\left(\mathrm{T}_{\mathrm{L}}\right)$ for a glass is the maximum temperature at which the molten glass and primary crystalline phase (e.g., spinel for DWPF) are at equilibrium. The constraint on liquidus temperature in the DWPF melter prevents melt pool crystallization during routine operation. This type of crystallization can involve almost simultaneous nucleation of the entire melt pool volume. Furthermore, once formed in the DWPF melter, spinel crystals are refractory and cannot be redissolved into the melt pool. When a significant amount of volume crystallization has occurred and the material has settled to the floor of the melter, the pour spout may become partially or completely blocked. In addition, the melt pool may no longer be able to sustain Joule heating which would cause the melt pool to solidify. Finally, minimizing volume crystallization simultaneously minimizes subsequent devitrification of the glass once it is poured into a canister. Thus, even though the $\mathrm{T}_{\mathrm{L}}$ constraint is non-waste-affecting, it is still imposes a very important limitation on the processability of a SME batch.

Glasses produced in DWPF must have liquidus temperatures below $1050^{\circ} \mathrm{C}$; this limit was defined to be safely below the nominal DWPF melter operating temperature of $1150^{\circ} \mathrm{C}$. However, the liquidus temperature of a glass cannot be measured in situ, and consequently, $\mathrm{T}_{\mathrm{L}}$-composition models have been pursued. Incorporating a newly developed $\mathrm{T}_{\mathrm{L}}$ model [20] into the SME acceptability decision and control system is one of the factors motivating the revision of this report.

The tendency of DWPF glasses to undergo crystallization was pursued employing a fourparameter model, which takes the form:

$$
\frac{1}{\mathrm{~T}_{\mathrm{L}}(\mathrm{K})}=\ln \left\{\left(\mathrm{M}_{2}\right)^{\mathrm{a}}\left(\mathrm{M}_{1}\right)^{\mathrm{b}}\left(\mathrm{M}_{\mathrm{T}}\right)^{\mathrm{c}}\right\}+\mathrm{d}=\mathrm{a} \ln \left(\mathrm{M}_{2}\right)+\mathrm{b} \ln \left(\mathrm{M}_{1}\right)+\mathrm{c} \ln \left(\mathrm{M}_{\mathrm{T}}\right)+\mathrm{d}
$$

or

$$
\mathrm{T}_{\mathrm{L}}\left({ }^{\mathrm{o}} \mathrm{C}\right)=\left\{\mathrm{a} \ln \left(\mathrm{M}_{2}\right)+\mathrm{b} \ln \left(\mathrm{M}_{1}\right)+\mathrm{c} \ln \left(\mathrm{M}_{\mathrm{T}}\right)+\mathrm{d}\right\}^{-1}-273
$$

where

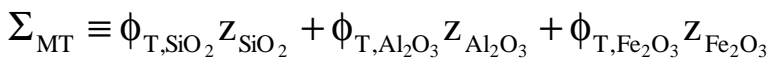

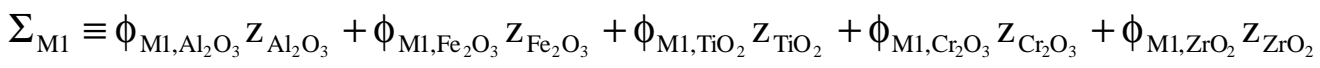

$$
\begin{aligned}
& +\phi_{\mathrm{M} 1, \mathrm{NiO}} \mathrm{z}_{\mathrm{NiO}}+\phi_{\mathrm{M} 1, \mathrm{MgO}} \mathrm{z}_{\mathrm{MgO}}+\phi_{\mathrm{M} 1, \mathrm{MnO}} \mathrm{z}_{\mathrm{MnO}} \\
& \Sigma_{\mathrm{M} 2} \equiv \phi_{\mathrm{M} 2, \mathrm{NiO}} \mathrm{Z}_{\mathrm{NiO}}+\phi_{\mathrm{M} 2, \mathrm{MgO}} \mathrm{Z}_{\mathrm{MgO}}+\phi_{\mathrm{M} 2, \mathrm{MnO}} \mathrm{Z}_{\mathrm{MnO}}+\phi_{\mathrm{M} 2, \mathrm{CaO}} \mathrm{Z}_{\mathrm{CaO}}
\end{aligned}
$$

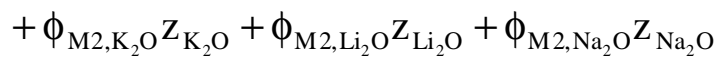

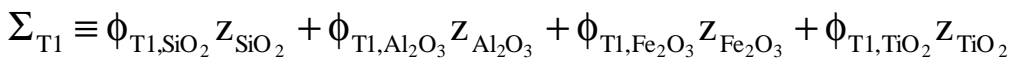

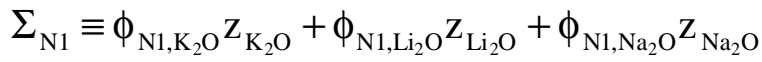

and 


$$
\mathrm{M}_{2} \equiv \frac{\Sigma_{\mathrm{M} 2}}{\Sigma}, \mathrm{M}_{1} \equiv \frac{\Sigma_{\mathrm{M} 1}}{\Sigma}, \mathrm{M}_{\mathrm{T}} \equiv \frac{\Sigma_{\mathrm{MT}}}{\Sigma} \text {, and } \Sigma \equiv \Sigma_{\mathrm{M} 2}+\Sigma_{\mathrm{M} 1}+\Sigma_{\mathrm{MT}}+\Sigma_{\mathrm{T} 1}+\Sigma_{\mathrm{N} 1}
$$

The $\phi$ coefficients [20] indicating the distribution of the various species are provided in Table 12. The least-squares results for the $\left(1 / \mathrm{T}_{\mathrm{L}}\right)$ versus the above expression for 105 model data representing DWPF compositions were used to estimate the parameters in the above model; these were $\mathrm{a}=-0.000260, \mathrm{~b}=-0.000566, \mathrm{c}=-0.000153$, and $\mathrm{d}=$ -0.00144 for the model data [20].

As may be apparent, the complexity of this new $\mathrm{T}_{\mathrm{L}}$-composition model precludes its being re-stated as a linear combination of the average molar oxide concentration (i.e., following the format of equation (1)). This leads to PAR and MAR determinations that are unique to the $\mathrm{T}_{\mathrm{L}}$ constraint [20].

Table 12. Speciation $(\phi)$ Coefficients Utilized in $\mathbf{T}_{\mathrm{L}}$ Model and Fitted Coefficients (a, b, c, and d)

\begin{tabular}{|c|c|c|c|c|c|c|}
\hline Speciation $(\phi)$ & M2 & M1 & MT & N1 & $\mathrm{T} 1$ & SUM \\
\hline $\mathrm{Al}_{2} \mathrm{O}_{3}$ & 0 & 0.0607 & 0.9393 & 0 & 0 & 1 \\
\hline $\mathrm{B}_{2} \mathrm{O}_{3}$ & 0 & 0 & 0 & 0 & 0 & 0 \\
\hline \multicolumn{2}{|l|}{$\mathrm{HCOO}$} & & & & & \\
\hline $\mathrm{CaO}$ & 0.029 & 0 & 0 & 0 & 0 & 0.029 \\
\hline \multicolumn{7}{|l|}{$\mathrm{Ce}_{2} \mathrm{O}_{3}$} \\
\hline $\mathrm{Cr}_{2} \mathrm{O}_{3}$ & 0 & 0.9202 & 0 & 0 & 0 & 0.9202 \\
\hline \multicolumn{7}{|l|}{$\mathrm{Cs}_{2} \mathrm{O}$} \\
\hline \multicolumn{7}{|l|}{$\mathrm{CuO}$} \\
\hline \multicolumn{7}{|l|}{$\mathrm{NaF}$} \\
\hline $\mathrm{Fe}_{2} \mathrm{O}_{3}$ & 0 & 0.1079 & 0.0193 & 0 & 0.6094 & 0.7366 \\
\hline $\mathrm{K}_{2} \mathrm{O}$ & 0.3041 & 0 & 0 & 0.1049 & 0 & 0.409 \\
\hline \multicolumn{7}{|l|}{$\mathrm{La}_{2} \mathrm{O}_{3}$} \\
\hline $\mathrm{Li}_{2} \mathrm{O}$ & 0.1745 & 0 & 0 & 0.1068 & 0 & 0.2813 \\
\hline $\mathrm{MgO}$ & 0.0167 & 0.0223 & 0 & 0 & 0 & 0.039 \\
\hline $\mathrm{MnO}$ & 0.994 & 0.00603 & 0 & 0 & 0 & 1 \\
\hline \multicolumn{7}{|l|}{$\mathrm{MoO}_{3}$} \\
\hline \multicolumn{7}{|l|}{$\mathrm{NO}_{2}$} \\
\hline $\mathrm{NO}_{3}$ & & & & & & \\
\hline $\mathrm{Na}_{2} \mathrm{O}$ & 0.1671 & 0 & 0 & 0.2518 & 0 & 0.4189 \\
\hline \multicolumn{7}{|l|}{$\mathrm{Na}_{2} \mathrm{SO}_{4}$} \\
\hline \multicolumn{7}{|l|}{$\mathrm{Nd}_{2} \mathrm{O} 3$} \\
\hline $\mathrm{NiO}$ & 0 & 0.1079 & 0 & 0 & 0 & 0.1079 \\
\hline \multicolumn{7}{|l|}{$\mathrm{P}_{2} \mathrm{O}_{5}$} \\
\hline \multicolumn{7}{|l|}{$\mathrm{PbO}$} \\
\hline $\mathrm{SiO}_{2}$ & 0 & 0 & 0.0193 & 0 & 0.0133 & 0.0326 \\
\hline \multicolumn{7}{|l|}{$\mathrm{ThO}_{2}$} \\
\hline $\mathrm{TiO}_{2}$ & 0 & 0.0568 & 0 & 0 & 0.5667 & 0.6235 \\
\hline $\mathrm{U}_{3} \mathrm{O}_{8}$ & 0 & 0 & 0 & 0 & 0 & 0 \\
\hline \multicolumn{7}{|l|}{$\mathrm{Y}_{2} \mathrm{O}_{3}$} \\
\hline $\mathrm{ZnO}$ & & & & & & \\
\hline $\mathrm{ZrO}_{2}$ & 0 & 0.0458 & 0 & 0 & 0 & 0.0458 \\
\hline
\end{tabular}




\subsubsection{Property ACCEPTANCE REgION For $\mathbf{T}_{\mathrm{L}}$}

The determination of the $\mathrm{T}_{\mathrm{L}}$ PAR is accomplished by accounting for the property model uncertainty for the new model and the approach is similar to that used for the viscosity constraints: a one-sided, 100(1- $\alpha) \%$ Scheffé simultaneous lower confidence band on the inverse of liquidus temperature (or $1 / \mathrm{T}_{\mathrm{L}}$ ) as given by:

$$
\text { Prediction }-\mathrm{s}_{\mathrm{r}} \sqrt{\mathrm{pF}_{2 \alpha}(\mathrm{p}, \mathrm{n}-\mathrm{p})} \sqrt{\underline{\mathrm{c}}_{0}\left(\mathbf{X}^{\mathrm{T}} \mathbf{X}\right)^{-1} \underline{\mathrm{c}}_{0}{ }^{\mathrm{T}}}
$$

where $s_{r}$ is the root mean square error (RMSE) of the fitted model, $F_{2 \alpha}(p, n-p)$, is the $100(1-2 \alpha) \%$ percentile of the F-distribution with $\mathrm{p}$ and $\mathrm{n}-\mathrm{p}$ degrees of freedom in numerator and denominator, respectively, $\underline{\mathrm{c}}_{0}$ is the vector of independent variables for which the prediction is to be made, and $\left(\mathbf{X}^{\mathrm{T}} \mathbf{X}\right)$ is the product moment matrix representing the independent variables used in fitting the model.

Because the inverse of liquidus temperature (or $1 / \mathrm{T}_{\mathrm{L}}$ ) is predicted, the $\mathrm{T}_{\mathrm{L}}$ constraint translates into a lower limit on $\left(1 / \mathrm{T}_{\mathrm{L}}\right)$ of approximately $7.56 \times 10^{-4} \mathrm{~K}^{-1}$. Therefore, the test for liquidus temperature should be one-sided based upon the one-sided lower bound on the $\left(1 / \mathrm{T}_{\mathrm{L}}\right)$ prediction, or:

$$
\frac{1}{\mathrm{~T}_{\mathrm{L}}(\mathrm{K})}-\mathrm{s}_{\mathrm{r}} \sqrt{\mathrm{pF}_{2 \alpha}(\mathrm{p}, \mathrm{n}-\mathrm{p})} \sqrt{\underline{\mathrm{c}}_{0}\left(\mathbf{X}^{\mathrm{T}} \mathbf{X}\right)^{-1} \underline{\mathrm{c}}_{0}{ }^{\mathrm{T}}} \geq 7.56 \times 10^{-4} \mathrm{~K}^{-1}
$$

where the predicted $\left(1 / \mathrm{T}_{\mathrm{L}}\right)$ is obtained using the model above. Re-stating this constraint using information generated during the fitting of the model [20] leads to

$$
\begin{aligned}
& \ln \left\{\left(\mathrm{M}_{2}\right)^{-0.000260}\left(\mathrm{M}_{1}\right)^{-0.000566}\left(\mathrm{M}_{\mathrm{T}}\right)^{-0.000153}\right\}-0.00144 \\
& -\left(2.28 \times 10^{-5}\right) \sqrt{\mathrm{pF}_{2 \alpha}(\mathrm{p}, \mathrm{N}-\mathrm{p})} \sqrt{\left[\begin{array}{rrrr}
105 & -126.56 & -309.14 & -162.47 \\
-126.56 & 154.22 & 371.50 & 194.98 \\
-309.14 & 371.50 & 913.84 & 473.73 \\
-162.47 & 194.98 & 473.73 & 265.64
\end{array}\right]^{-1}} \xi^{\mathrm{T}} \geq 7.56 \times 10^{-4} \mathrm{~K}^{-1}
\end{aligned}
$$

where $\xi$ is defined to be the vector (i.e., $\left[1 \ln \left(\mathrm{M}_{2}\right) \ln \left(\mathrm{M}_{1}\right) \ln \left(\mathrm{M}_{\mathrm{T}}\right)\right]$ ) of values at which to predict $\left(1 / \mathrm{T}_{\mathrm{L}}\right), \mathrm{p}=4$, and $\mathrm{n}=135, \mathrm{a}=0.05$ (or 5\%), and thus, $\mathrm{F}_{0.10}(4,131)=2.0014$ Thus, for a given SME composition, compute the values of $\ln \left(\mathrm{M}_{2}\right), \ln \left(\mathrm{M}_{1}\right)$, and $\ln \left(\mathrm{M}_{\mathrm{T}}\right)$ and see if this inequality is satisfied. If so, the composition is in the $\mathrm{T}_{\mathrm{L}} \mathrm{PAR}$.

Another way of looking at the PAR for this constraint is to invert the PAR limit (after converting from Kelvin to the Celsius scale) for $1 / \mathrm{T}_{\mathrm{L}}$ determined above subtract away the predicted $\mathrm{T}_{\mathrm{L}}$ derived from the model and use this difference to represent the property prediction uncertainty. This amount can then be subtracted from the $1050{ }^{\circ} \mathrm{C}$ EPAR limit 
to obtain the PAR limit in ${ }^{\circ} \mathrm{C}$ against which the $\mathrm{T}_{\mathrm{L}}$ prediction can be directly compared. That is the predicted $\mathrm{T}_{\mathrm{L}}$ has to be below this PAR limit expressed in degrees Celsius for the SME composition to be within the liquidus temperature PAR (with 95\% confidence).

\subsubsection{MeASUREMENT ACCEPTANCE REGION FOR T}

In addition to the property uncertainty addressed in the previous section, any errors associated with measuring the SME composition from which the liquidus temperature is predicted must be introduced to assure that the glass in question will not crystallize in the DWPF melter. To estimate the relevant measurement uncertainties for a given composition, the errors for the measured concentrations are first propagated through the model and the resulting variances and pair-wise covariances summed to provide an estimate of the measurement variance. Using this approach (as detailed in [20]), the estimated variance is given by:

$$
\mathrm{V}\left(\frac{1}{\mathrm{~T}_{\mathrm{L}}}\right) \approx \sum_{\mathrm{i}} \sum_{\mathrm{j}}\left\{\left[\frac{\partial}{\partial[\mathrm{i}]}\left(\frac{1}{\mathrm{~T}_{\mathrm{L}}}\right)_{\text {pred }}\right]\left(\mathrm{r}_{\mathrm{i}}[\mathrm{i}]\left[\frac{\partial}{\partial[\mathrm{j}]}\left(\frac{1}{\mathrm{~T}_{\mathrm{L}}}\right)_{\text {pred }}\right]\left(\mathrm{r}_{\mathrm{j}}[\mathrm{j}]\right) \mathrm{p}_{\mathrm{i}, \mathrm{j}}\right\}\right.
$$

for $\mathrm{i}$ and $\mathrm{j}$ from $\left\{\mathrm{Al}_{2} \mathrm{O}_{3}, \mathrm{CaO}, \mathrm{Cr}_{2} \mathrm{O}_{3}, \mathrm{Fe}_{2} \mathrm{O}_{3}, \mathrm{~K}_{2} \mathrm{O}, \mathrm{Li}_{2} \mathrm{O}, \mathrm{Na}_{2} \mathrm{O}, \mathrm{MgO}, \mathrm{MnO}, \mathrm{NiO}, \mathrm{SiO}_{2}\right.$, $\mathrm{TiO}_{2}$, and $\left.\mathrm{ZrO}_{2}\right\}$ with

$$
\left(\frac{1}{\mathrm{~T}_{\mathrm{L}}}\right)_{\text {pred }} \equiv \ln \left\{\left(\mathrm{M}_{2}\right)^{-0.000260}\left(\mathrm{M}_{1}\right)^{-0.000566}\left(\mathrm{M}_{\mathrm{T}}\right)^{-0.000153}\right\}-0.00144
$$

In the above expression, $r_{i},[i]$, and $\rho_{i, j}$ are the relative standard deviation, molar concentration (on a $100 \mathrm{~g}$ glass basis), and correlation coefficient, respectively. As in the determinations for the MARs for the other constraints, there are two options for representing the molar concentrations (i.e., the [i]'s): the historical average molar composition (see Table A5 in Appendix A) upon which the relative standard deviations (see Table A6 in Appendix A) and correlations (see Table A4 in Appendix A) were estimated and the average molar composition for the current SME batch, $\underline{Z}_{n}$. Once again, both representations will be considered with the larger measurement uncertainty from the two selected for use in the defining the $\mathrm{T}_{\mathrm{L}} \mathrm{MAR}$.

The details of the estimation of the measurement variance are provided in [20]. Table12 summarizes the critical information needed in evaluating the partial derivatives for each molar oxide of interest. In this table, the vector of partial derivatives (evaluated at the SME composition, $\underline{z}_{n}$ ) is represented by $\underline{p}$. 
Table 12. Evaluation of Partial Derivatives at SME Average Molar Composition

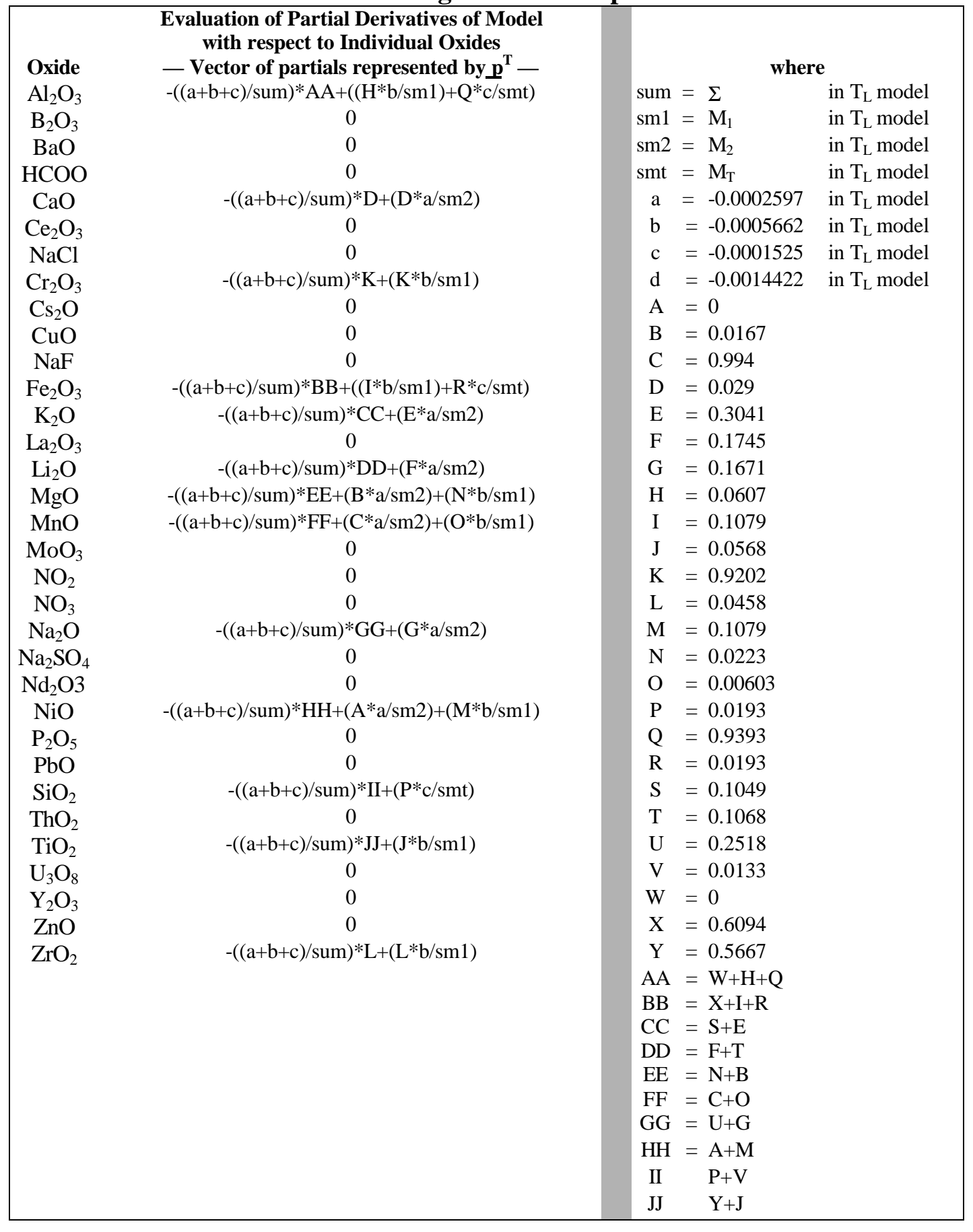

As previously stated the measurement uncertainty is to be computed using both the historical and current SME compositions. These calculations are made relative to the PAR limit computed in the previous section. First, consider the measurement uncertainty derived using the current SME composition. Let the vector $\underline{r}$ represent the relative 


\section{Revision 4}

standard deviations of Table B3 and $\underline{\mathrm{C}}_{\mathrm{m}}$ represents the correlation matrix of Table B1, then compute the vector $\underline{\mathrm{s}}_{\mathrm{m}}$ by

$$
\underline{\mathrm{S}}_{\mathrm{m}}=(\underline{\mathrm{z}} \# \underline{\mathrm{r}} \# \underline{\mathrm{p}})
$$

where the operator \# implies element by element multiplication between two vectors. Next, compute $S_{\mathrm{m}}$ as

$$
\mathrm{S}_{\mathrm{m}}=\underline{\mathrm{S}}_{\mathrm{m}} * \underline{\mathrm{C}}_{\mathrm{m}} * \underline{\mathrm{S}}_{\mathrm{m}}
$$

The final step in assessing the impact of measurement uncertainty using the current SME composition is to compute:

$$
\mathrm{MAR}_{\text {current }}=\operatorname{PAR}_{1 / \mathrm{r}_{\mathrm{L}}}+\mathrm{t}_{\alpha}(\mathrm{m}-1) \cdot \sqrt{\mathrm{S}_{\mathrm{m} / 4}}
$$

where $\mathrm{PAR}_{1 / \mathrm{T}_{\mathrm{L}}}$ represents the PAR limit as $1 / \mathrm{T}_{\mathrm{L}}$ (i.e., for the original model) and $t_{\alpha}(\mathrm{m}-1)$ is the upper $100 \alpha \%$ tail of the Student's t distribution with m-1 degrees of freedom.

A similar approach is used to estimate the measurement uncertainty derived using the historical composition. Let the vectors $\mathrm{g}$ and $\underline{\mathrm{M}}$ represent the gravimetric factors and molecular weights, respectively, of Table A2 and the vector $\underline{h}$ represent the historical elemental compositions of Table B2, then compute the vector $\underline{s}_{n}$ by

$$
\underline{\mathrm{s}}_{\mathrm{n}}=(\mathrm{g} \# \mathrm{~h} \# \underline{\mathrm{r}} \# \underline{\mathrm{p}}) / \mathrm{M}
$$

where once again, the operator \# implies element by element multiplication between two vectors and the division represented by " $/$ " is also element by element.

Next, compute $S_{n}$ as

$$
\mathrm{S}_{\mathrm{n}}=\underline{\mathrm{S}}_{\mathrm{n}} * \underline{\mathrm{C}}_{\mathrm{m}} * \underline{\mathrm{s}}_{\mathrm{n}}
$$

The final step in assessing the impact of measurement uncertainty using the historical composition is to compute:

$$
\operatorname{MAR}_{\text {historical }}=\operatorname{PAR}_{1 / r_{\mathrm{L}}}+\mathrm{t}_{\alpha}(\mathrm{m}-1) \cdot \sqrt{\mathrm{S}_{\mathrm{n} / 4}}
$$

where $\mathrm{PAR}_{1 / \mathrm{T}_{\mathrm{L}}}$ represents the PAR limit as $1 / \mathrm{T}_{\mathrm{L}}$ (i.e., for the original model) and $\mathrm{t}_{\alpha}(\mathrm{m}-1)$ is the upper $100 \alpha \%$ tail of the Student's t distribution with m-1 degrees of freedom.

As the final step in assessing the measurement uncertainty for the liquidus temperature model, find the larger of $\mathrm{MAR}_{\text {historical }}$ and $\mathrm{MAR}_{\text {current }}$; call this value, MAR $\mathrm{M}_{\mathrm{I}_{\mathrm{L}}}$, since it is still in is in terms of $1 / T_{L}$. This MAR limit may be expressed in degrees Celsius as 


$$
\operatorname{MAR}_{\mathrm{T}_{\mathrm{L}}}=\left(1 / \mathrm{MAR}_{\mathrm{y}_{\mathrm{L}}}\right)-273
$$

A SME composition with a predicted $\mathrm{T}_{\mathrm{L}}$ value less than $\mathrm{MAR}_{\mathrm{T}_{\mathrm{L}}}$ would satisfy the liquidus temperature MAR with $95 \%$ confidence. Note that the nominal $95 \%$ confidence level (equal to $100[1-\alpha] \%$ ) for the $\mathrm{T}_{\mathrm{L}}$ constraint can be adjusted based upon management discretion.

\section{REDOX CONSIDERATIONS}

The majority of elements considered in PCCS possess only a single corresponding oxidethey are assumed to be either completely oxidized or reduced at current DWPF melter conditions-as indicated by Schreiber $[1,21]$. There is only one exception: copper, ${ }^{\dagger}$ which is discussed in Section 6.1. DWPF does not currently measure the reduction/oxidation (redox) ratio for their SME feed due to the highly oxidized nature of the DWPF melt (i.e., $\left[\mathrm{Fe}^{3+}\right]>>\left[\mathrm{Fe}^{2+}\right]$ ). Furthermore, the redox test is not sensitive enough to detect redox ratios of less than 0.10 [13]. Therefore, this ratio is assumed to be zero for current DWPF use (i.e., currently all Fe will be converted to $\mathrm{Fe}_{2} \mathrm{O}_{3}$ - see Section 6.2 for a discussion regarding $\mathrm{Fe}$ under more general redox conditions). Alternatively the elemental copper will be approximately half reduced and half oxidized in the DWPF glasses - this has an impact on both the durability and conservation constraint calculations. ${ }^{\dagger \dagger}$

\subsection{REDOX ISSUES FOR CU}

The ratio of $\mathrm{Cu}^{1+}$ (reduced) to total copper (i.e., $\mathrm{Cu}^{1+}$ and $\mathrm{Cu}^{2+}$ ) is assumed to be 0.5 based upon Schreiber's work [1, 21]. The concentrations of $\mathrm{Cu}_{2} \mathrm{O}$ (reduced) and $\mathrm{CuO}$ (oxidized) are thus:

$$
\begin{aligned}
& \phi_{\mathrm{Cu}} \equiv \frac{\mathrm{g} \mathrm{Cu}^{1+}}{\mathrm{g} \mathrm{Cu}^{1+}+\mathrm{g} \mathrm{Cu}^{2+}} \text { and } \frac{\mathrm{g} \mathrm{Cu}^{2+}}{\mathrm{g} \mathrm{Cu}^{1+}+\mathrm{g} \mathrm{Cu}^{2+}}=1-\phi_{\mathrm{Cu}} \\
& \text { and } \underline{\mathrm{x}}_{\mathrm{Cu}} \equiv \frac{\mathrm{g} \mathrm{Cu}}{100 \mathrm{~g} \text { glass }}=\frac{\mathrm{g} \mathrm{Cu}^{1+}+\mathrm{g} \mathrm{Cu}^{2+}}{100 \mathrm{~g} \text { glass }} \\
& \text { or } \underline{\mathrm{z}}_{\mathrm{Cu}_{2} \mathrm{O}}=\frac{\gamma_{\mathrm{Cu}_{2} \mathrm{O}}}{\mathrm{M}_{\mathrm{Cu}_{2} \mathrm{O}}} \phi_{\mathrm{Cu}} \underline{\mathrm{x}}_{\mathrm{Cu}} \text { and } \underline{\mathrm{z}}_{\mathrm{CuO}}=\frac{\gamma_{\mathrm{CuO}}}{\mathrm{M}_{\mathrm{CuO}}}\left[1-\phi_{\mathrm{Cu}} \underline{\mathrm{x}}_{\mathrm{Cu}} .\right.
\end{aligned}
$$

For durability, the contribution to the total free energy of hydration for copper is:

$\dagger$ For DWPF use, elemental iron is properly assumed to be completely oxidized [1, 21]. Manganese is the only element that will be almost completely reduced in DWPF glasses; therefore, its corresponding oxide is $\mathrm{MnO} .[21]$

${ }^{\dagger}$ This has no impact on the copper constraint, which is based on total elemental copper as is measured during DWPF processing.

$\ddagger$ Both copper $\mathrm{G}_{\mathrm{i}}$ coefficients have the free energy for silica subtracted from them since they both form silicates according to Ref. 1. 


$$
\left(\Delta \mathrm{G}_{\mathrm{Cu}_{2} \mathrm{O}}-\Delta \mathrm{G}_{\mathrm{SiO}_{2}}\right) \underline{\mathrm{z}}_{\mathrm{Cu}_{2} \mathrm{O}}+\left(\Delta \mathrm{G}_{\mathrm{CuO}}-\Delta \mathrm{G}_{\mathrm{SiO}_{2}} \underline{\mathrm{CuO}}_{\mathrm{CuO}}\right.
$$

where the copper $G_{i}$ coefficients are taken from Reference 1. It would be desirable to define an aggregate $\mathrm{G}_{\mathrm{i}}$ for copper, designated $\Delta \mathrm{G}_{\mathrm{Cu}_{\mathrm{x}} \mathrm{O}}$, that would allow the copper free energy contribution to be estimated from the total elemental copper concentration if the copper is assumed to be completely oxidized (i.e., all $\mathrm{Cu}$ is converted to $\mathrm{CuO}$ ). This would take the form:

$$
\left(\Delta \mathrm{G}_{\mathrm{Cu}_{x} \mathrm{O}}-\Delta \mathrm{G}_{\mathrm{SiO}_{2}}\right) \underline{\mathrm{z}}_{\mathrm{All} \mathrm{Cu} \text { as CuO }} \equiv\left(\Delta \mathrm{G}_{\mathrm{Cu}_{2} \mathrm{O}}-\Delta \mathrm{G}_{\mathrm{SiO}_{2}}\right) \underline{\mathrm{Z}}_{\mathrm{Cu}_{2} \mathrm{O}}+\left(\Delta \mathrm{G}_{\mathrm{CuO}}-\Delta \mathrm{G}_{\mathrm{SiO}_{2}}\right) \underline{\mathrm{z}}_{\mathrm{CuO}}
$$

The copper could then be managed in the same fashion as all other elements in the durability constraint computations (i.e., it would posses a single corresponding oxide). This aggregate $\mathrm{G}_{\mathrm{i}}$ coefficient is then:

$$
\Delta \mathrm{G}_{\mathrm{Cu}_{\mathrm{x}} \mathrm{O}} \equiv \phi_{\mathrm{Cu}}\left(\frac{\gamma_{\mathrm{Cu}_{2} \mathrm{O}}}{\mathrm{M}_{\mathrm{Cu}_{2} \mathrm{O}}}\right)\left(\frac{\mathrm{M}_{\mathrm{CuO}}}{\gamma_{\mathrm{CuO}}}\right)\left(\Delta \mathrm{G}_{\mathrm{Cu}_{2} \mathrm{O}}-\Delta \mathrm{G}_{\mathrm{SiO}_{2}}\right)+\left(1-\phi_{\mathrm{Cu}}\right)\left(\Delta \mathrm{G}_{\mathrm{CuO}}-\Delta \mathrm{G}_{\mathrm{SiO}_{2}}\right)+\Delta \mathrm{G}_{\mathrm{SiO}_{2}}
$$

Similarly, the conservation of mass constraint is affected by the differing possible complexes of copper in the DWPF melt. The oxide contribution for copper should be:

$$
\frac{\mathrm{g} \mathrm{Cu} 2 \mathrm{O}+\mathrm{g} \mathrm{CuO}}{100 \mathrm{~g} \text { glass }} \equiv \phi_{\mathrm{Cu}} \gamma_{\mathrm{Cu}_{2} \mathrm{O}} \underline{\mathrm{x}}_{\mathrm{Cu}}+\left(1-\phi_{\mathrm{Cu}}\right) \gamma_{\mathrm{CuO}} \underline{\mathrm{x}}_{\mathrm{Cu}}
$$

However, if all copper is assumed to be oxidized, the following contribution is actually made to the oxide sum due to copper:

$$
\frac{\mathrm{g} \mathrm{CuO}}{100 \mathrm{~g} \text { glass }} \equiv \gamma_{\mathrm{CuO}} \underline{\mathrm{x}}_{\mathrm{Cu}}
$$

Therefore, the constraint coefficient for conservation must be multiplied by a factor of:

$$
\frac{\phi_{\mathrm{Cu}} \gamma_{\mathrm{Cu}_{2} \mathrm{O}}+\left(1-\phi_{\mathrm{Cu}}\right) \gamma_{\mathrm{CuO}}}{\gamma_{\mathrm{CuO}}}
$$

to assure that the correct contribution is made for copper. Thus all copper can be considered oxidized without invalidating any property constraints.

The assumptions and manipulations made concerning copper and its corresponding oxide form do not impact the variance estimates computed for acceptability testing. In DWPF only total copper will be measured; therefore, only the total elemental copper has a 
variance component associated with it. ${ }^{\dagger}$ Using the above transformations, i.e., assuming the copper is oxidized, will provide the appropriate variance component for testing.

\subsection{REDOX ISSUES FOR FE}

As previously stated two cations ( $\mathrm{Cu}$ and Fe) in PCCS are considered multivalent at expected DWPF operating conditions. That is, the $\mathrm{Cu}$ can be in either the I or II state (and is currently assumed to be a 50/50 split of the two) and the Fe can be in either the II or III state (and is currently considered to be entirely oxidized or in the III state). As illustrated in the previous section, this impacts two sets of constraints (i.e., those on durability and those on mass conservation). Because of the inherent imprecision of the redox determination, it is only desired to bound the potential impact of the multivalent cations on glass durability as described the durability model predictions.

A derivation for $\mathrm{Fe}$ similar to that used for $\mathrm{Cu}$ in the previous section supplies the appropriate $\Delta \mathrm{G}_{\mathrm{p}}$ coefficient, $\Delta \mathrm{G}_{\mathrm{Fe}_{\mathrm{x}} \mathrm{O}_{\mathrm{y}}}$, for Fe under more general redox conditions:

$$
\Delta \mathrm{G}_{\mathrm{Fe}_{\mathrm{x}} \mathrm{O}_{\mathrm{y}}} \equiv \phi_{\mathrm{Fe}}\left(\frac{\gamma_{\mathrm{FeO}}}{\mathrm{M}_{\mathrm{FeO}}}\right)\left(\frac{\mathrm{M}_{\mathrm{Fe}_{2} \mathrm{O}_{3}}}{\gamma_{\mathrm{Fe}_{2} \mathrm{O}_{3}}}\right)\left(\Delta \mathrm{G}_{\mathrm{FeO}}-\Delta \mathrm{G}_{\mathrm{SiO}_{\mathrm{x}}}\right)+\left(1-\phi_{\mathrm{Fe}}\right) \Delta \mathrm{G}_{\mathrm{Fe}_{2} \mathrm{O}_{3}}
$$

where $\phi_{\mathrm{Fe}}$ is the fraction of iron in the II state. This allows computation of the correct $\Delta \mathrm{G}_{\mathrm{p}}$ contribution for multivalent iron when the $\mathrm{Fe}_{2} \mathrm{O}_{3}$ molar concentration is used for durability prediction. However, in the current implementation of the control strategy for the DWPF $\phi_{\mathrm{Fe}}$ assumed to be 0 .

\section{PCCS Sample Calculation}

In this section, a sample calculation of the SME Acceptability determination is provided. Table 13 provides the starting place for these calculations - a set of chemical composition measurements generated from a collection of $n=4$ SME samples. The last column of the table provides the average of the 4 samples and it is this composition that is to be assessed in the illustrative calculation. (Note that this average composition is the same composition used for the sample calculation in revision 3 of this report.)

The ratio of reduced to total copper is assumed to be known and thus has no variance contribution. 
Table 13. Average Chemical Composition Used in Sample Calculations

\begin{tabular}{|c|c|c|c|c|c|c|}
\hline Element/ & Unit of & & Sample & Data & & \\
\hline Anion & Measure & 1 & 2 & 3 & 4 & Average \\
\hline Solids & $w t \%$ & 45.02 & 48.00 & 43.61 & 43.37 & 45.00 \\
\hline Calcined Solids & $w t \%$ & 38.76 & 43.34 & 40.78 & 37.12 & 40.00 \\
\hline Spec Gravity & $\mathrm{g} / \mathrm{mL}$ & 1.371 & 1.463 & 1.478 & 1.388 & 1.425 \\
\hline Al & $w t \%$ & 2.1489 & 2.0122 & 1.9630 & 1.8959 & 2.0050 \\
\hline B & $w t \%$ & 2.6493 & 2.3431 & 2.5998 & 2.4118 & 2.5010 \\
\hline $\mathrm{Ba}$ & $w t \%$ & & & & & \\
\hline $\mathrm{Ca}$ & $w t \%$ & 0.5970 & 0.6351 & 0.6628 & 0.7055 & 0.6501 \\
\hline $\mathrm{Ce}$ & wt\% & & & & & \\
\hline $\begin{array}{l}\mathrm{Cr} \\
\mathrm{Cs}\end{array}$ & $\begin{array}{l}w t \% \\
w t \%\end{array}$ & 0.0535 & 0.0579 & 0.0565 & 0.0635 & 0.0579 \\
\hline $\mathrm{Cu}$ & wt\% & 0.2882 & 0.2789 & 0.2967 & 0.2550 & 0.2797 \\
\hline $\mathrm{Fe}$ & wt\% & 7.6499 & 7.7636 & 7.3672 & 8.4353 & 7.8040 \\
\hline $\mathbf{K}$ & $w t \%$ & 2.2401 & 2.1667 & 2.0668 & 1.9864 & 2.1150 \\
\hline La & $w t \%$ & & & & & \\
\hline Li & wt\% & 2.1320 & 2.2942 & 2.0782 & 2.0076 & 2.1280 \\
\hline $\mathbf{M g}$ & $w t \%$ & 0.8291 & 0.8440 & 0.8656 & 0.8977 & 0.8591 \\
\hline Mn & $w t \%$ & 1.6210 & 1.5257 & 1.4975 & 1.6438 & 1.5720 \\
\hline Mo & $w t \%$ & & & & & \\
\hline $\mathrm{Na}$ & wt\% & 7.2587 & 6.9136 & 7.6605 & 7.5752 & 7.3520 \\
\hline Nd & $w t \%$ & & & & & \\
\hline $\mathbf{N i}$ & $w t \%$ & 0.8010 & 0.8440 & 0.8175 & 0.8767 & 0.8348 \\
\hline $\mathrm{Pb}$ & $w t \%$ & & & & & \\
\hline Si & wt\% & 23.3266 & 22.2498 & 23.6869 & 27.5767 & 24.2100 \\
\hline Th & $w t \%$ & & & & & \\
\hline $\mathrm{Ti}$ & $w t \%$ & 0.0614 & 0.0647 & 0.0624 & 0.0555 & 0.0610 \\
\hline $\mathbf{U}$ & $w t \%$ & & & & & \\
\hline $\mathbf{Y}$ & $w t \%$ & & & & & \\
\hline $\mathrm{Zn}$ & $w t \%$ & & & & & \\
\hline $\mathrm{Zr}$ & $w t \%$ & 0.8187 & 0.7858 & 0.8185 & 0.9506 & 0.8434 \\
\hline $\mathrm{Cl}$ & ppm & 102 & 98 & 100 & 100 & 100 \\
\hline $\mathbf{F}$ & ppm & 95 & 100 & 93 & 112 & 100 \\
\hline $\mathrm{HCOO}$ & ppm & & & & & \\
\hline NO2 & ppm & & & & & \\
\hline NO3 & ppm & & & & & \\
\hline PO4 & ppm & 99 & 96 & 106 & 99 & 100 \\
\hline SO4 & ppm & 104 & 102 & 94 & 100 & 100 \\
\hline TOC & ppm & & & & & \\
\hline
\end{tabular}

Using the information of Table 13 and the gravimetric factors and molecular weights as directed in Table A2 of the Appendix A, the corresponding molar oxide weight percents can be calculated. This is accomplished for each element whose concentration is reported in $\mathrm{wt} \%$ by multiplying the $\mathrm{wt} \%$ value by the appropriate gravimetric factor and dividing by the molecular weight of the corresponding oxide. For each anion of Table 13 (reported in ppm), the determination of the corresponding molar oxide concentration is conducted using the calcined wt $\%$ solids (the average measurement from Table 13) as discussed in Appendix A. That is, the ppm value of the anion is divided by 100 times the calcined wt\% solids value; then, the result is multiplied by the appropriate gravimetric factor and divided by the molecular weight of the corresponding oxide to compute the 
desired molar oxide concentration. As a final comment on the determination of the molar oxide concentrations for the SME batch, note that the components $\mathrm{HCOO}, \mathrm{NO}_{2}$, and $\mathrm{NO}_{3}$ are not used by the control system (i.e., these constituents are not used in the PCCS calculations). More specifically, these constituents are not involved in any way in any of the constraints (process, product, or solubility) associated with PCCS.

\section{Table 14. Molar Oxide Concentrations for Sample Calculation}

\begin{tabular}{|cc|}
\hline $\mathrm{Oxide}_{2}$ & Molar Oxide Concentration \\
\hline $\mathrm{Al}_{2} \mathrm{O}_{3}$ & 0.0372 \\
$\mathrm{~B}_{2} \mathrm{O}_{3}$ & 0.1157 \\
$\mathrm{BaO}$ & 0.0000 \\
$\mathrm{HCOO}$ & Not Used \\
$\mathrm{CaO}$ & 0.0162 \\
$\mathrm{Ce} \mathrm{O}_{3}$ & 0.0000 \\
$\mathrm{NaCl}$ & 0.0007 \\
$\mathrm{Cr} \mathrm{O}_{3}$ & 0.0006 \\
$\mathrm{Cs} \mathrm{O}_{2}$ & 0.0000 \\
$\mathrm{CuO}$ & 0.0044 \\
$\mathrm{NaF}$ & 0.0013 \\
$\mathrm{Fe}_{2} \mathrm{O}_{3}$ & 0.0699 \\
$\mathrm{~K}_{2} \mathrm{O}$ & 0.0270 \\
$\mathrm{La}_{2} \mathrm{O}_{3}$ & 0.0000 \\
$\mathrm{Li}_{2} \mathrm{O}$ & 0.1533 \\
$\mathrm{MgO}$ & 0.0353 \\
$\mathrm{MnO}_{\mathrm{MoO}_{3}}$ & 0.0286 \\
$\mathrm{NO}_{2}$ & 0.0000 \\
$\mathrm{NO}_{3}$ & Not Used \\
$\mathrm{Na}_{2} \mathrm{O}$ & 0.1599 \\
$\mathrm{Na}_{2} \mathrm{SO}_{4}$ & 0.0003 \\
$\mathrm{Nd}_{2} \mathrm{O} 3$ & 0.0000 \\
$\mathrm{NiO}_{2}$ & 0.0142 \\
$\mathrm{P}_{2} \mathrm{O}_{5}$ & 0.0001 \\
$\mathrm{PbO}$ & 0.0000 \\
$\mathrm{SiO}_{2}$ & 0.8620 \\
$\mathrm{ThO}_{2}$ & 0.0000 \\
$\mathrm{TiO}_{2}$ & 0.0013 \\
$\mathrm{U}_{3} \mathrm{O}_{8}$ & 0.0000 \\
$\mathrm{Y}_{2} \mathrm{O}_{3}$ & 0.0000 \\
$\mathrm{ZnO}_{\mathrm{ZrO}_{2}}$ & 0.0000 \\
$\mathrm{HO}_{2}$ & 0.0092 \\
\hline
\end{tabular}

In the preceding discussions, the vector $\underline{\mathrm{z}}$ was used to represent, for a given SME batch, the average molar oxide concentrations, such as those provided in Table 14. For each of the constraints except for $\mathrm{T}_{\mathrm{L}}$, the PAR evaluation for the constraint involves a linear combination of the $\underline{z}$ vector and a corresponding offset in the form of an inequality. Equation (1) provides the general form for each of these inequalities, and Table 15 provides the a vectors and the $\beta$ 's (the offsets) that complete the information necessary to evaluate the PAR limits for these constraints. 
Using the approach of Appendix A, for each of these constraints (i.e., all of the constraints except $T_{L}$ ), the MAR limit is defined as:

$$
\underline{\mathrm{za}}^{\mathrm{T}}-\beta-\mathrm{t}_{\alpha}(\mathrm{m}-1) \sqrt{\frac{\underline{\mathrm{a}}_{\underline{\mathrm{a}}^{\mathrm{T}}}^{\mathrm{T}}}{\mathrm{n}}} \geq 0
$$

where $\quad t_{\alpha}(m-1)$ represents the upper $100 \alpha \%$ tail of the Student's t distribution with $\mathrm{m}-1$ degrees of freedom and

$$
\frac{\underline{\mathrm{a}} \underline{\mathbf{S}}^{\mathrm{T}}}{\mathrm{n}} \equiv \operatorname{maximum}\left[\begin{array}{l}
\frac{\left(\underline{a}_{i}\right) \mathbf{S}_{\mathrm{m}}\left(\underline{a}_{\mathrm{i}}\right)^{\mathrm{T}}}{\mathrm{n}}=\frac{1}{\mathrm{n}} \sum_{\mathrm{j}=0}^{\mathrm{q}-1} \sum_{\mathrm{k}=0}^{\mathrm{q}-1}\left(\underline{a}_{\mathrm{i}}\right)_{\mathrm{j}}\left(\underline{a}_{\mathrm{i}}\right)_{\mathrm{k}}\left(\mathbf{S}_{\mathrm{m}}\right)_{j, \mathrm{k}} \\
\frac{\left(\underline{\mathrm{a}}_{\mathrm{i}}\right) \mathbf{S}_{\mathrm{n}}\left(\underline{\mathrm{a}}_{\mathrm{i}}\right)^{\mathrm{T}}}{\mathrm{n}}=\frac{1}{\mathrm{n}} \sum_{\mathrm{j}=0}^{\mathrm{q}-1} \sum_{\mathrm{k}=0}^{\mathrm{q}-1}\left(\underline{a}_{\mathrm{i}}\right)_{\mathrm{j}}\left(\underline{a}_{\mathrm{i}}\right)_{\mathrm{k}}\left(\mathbf{S}_{\mathrm{n}}\right)_{j, \mathrm{k}}
\end{array}\right]
$$

with $S_{m}$ and $S_{n}$ representing the covariance matrices (an absolute based upon historical data versus a relative based upon the current $\underline{\mathrm{z}}$ vector, respectively) as described in Appendix B.

To illustrate the calculations, the MAR limits are computed both for the absolute-error model using the "historical" data of Table A4 as

$$
\operatorname{MAR}_{\text {Historical }}=\beta+\mathrm{t}_{\alpha}(\mathrm{m}-1) \sqrt{\frac{\mathrm{a}_{\mathrm{m}} \underline{\mathrm{a}}^{\mathrm{T}}}{\mathrm{n}}} \geq 0
$$

and for the relative-error model using the "current" (i.e., z ) data of Table 13 as

$$
\operatorname{MAR}_{\text {Current }}=\beta+t_{\alpha}(m-1) \sqrt{\frac{\underline{a}_{n} \underline{a}^{T}}{n}} \geq 0
$$

The larger of these two values for each constraint is selected as the MAR limit.

The derived value, $\underline{\mathrm{za}}^{\mathrm{T}}$, for each constraint is compared to its MAR limit:

$$
\text { if } \underline{\mathrm{za}}^{\mathrm{T}}-\mathrm{MAR}=\text { MAR difference }>0,
$$

then the composition satisfies the MAR limit for the given constraint.

Table 16 provides the result of these calculations for all of the constraints except for $\mathrm{T}_{\mathrm{L}}$. 
Table 15. a Vectors and PAR Limits (Offsets, $\beta$ 's) for all Constraints Except $T_{L}$

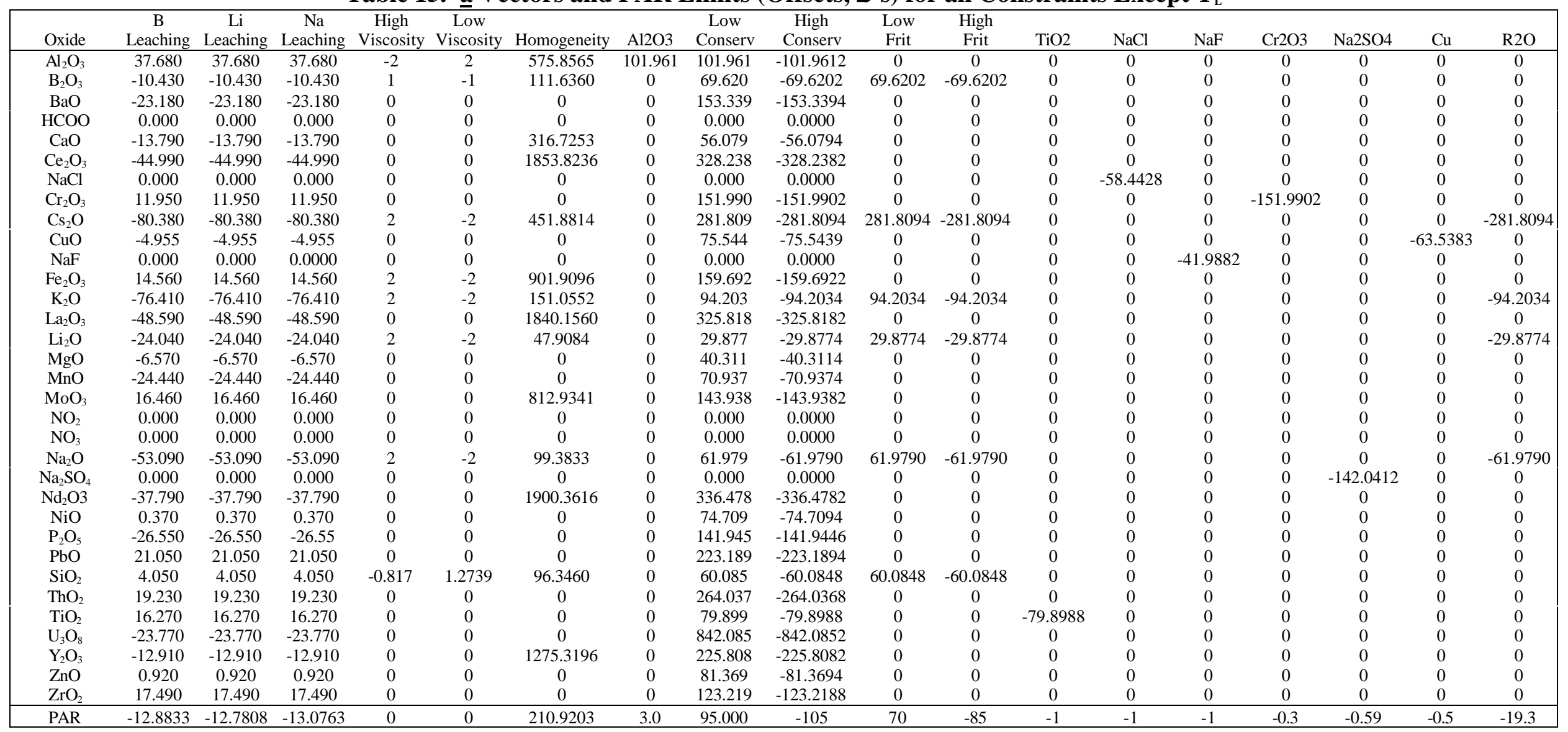


Table 17. Results of Sample Calculations for All Constraints Except $\mathbf{T}_{\mathrm{L}}$

\begin{tabular}{|c|c|c|c|c|c|c|c|c|}
\hline $\begin{array}{l}\text { PCCS } \\
\text { Constraint }\end{array}$ & $\begin{array}{l}\text { Historical Error Model } \\
\text { MAR Limit }\end{array}$ & $\begin{array}{c}\text { Current Error Model } \\
\text { MAR Limit }\end{array}$ & $\begin{array}{l}\text { MAR } \\
\text { Limit }\end{array}$ & $\begin{array}{l}\text { Derived Value } \\
\text { for Constraint }\end{array}$ & MAR Diff & & $\begin{array}{c}\text { Process/ } \\
\text { Property } \\
\text { Value }\end{array}$ & $\begin{array}{c}\text { Property Unit } \\
\text { of Measure }\end{array}$ \\
\hline B Leaching & -12.497 & -12.527 & -12.497 & -10.526 & 1.971 & B Leaching & 1.014 & $\mathrm{~g} / \mathrm{L}$ \\
\hline Li Leaching & -12.395 & -12.425 & -12.395 & -10.526 & 1.869 & Li Leaching & 0.998 & $\mathrm{~g} / \mathrm{L}$ \\
\hline Na Leaching & -12.690 & -12.720 & -12.690 & -10.526 & 2.164 & Na Leaching & 0.997 & $\mathrm{~g} / \mathrm{L}$ \\
\hline High Viscosity & 0.013 & 0.013 & 0.013 & 0.157 & 0.145 & Hi Viscosity & 55.61 & poise \\
\hline Low Viscosity & 0.029 & 0.029 & 0.029 & 0.236 & 0.207 & Lo Viscosity & 55.61 & poise \\
\hline Homogeneity & 218.743 & 219.110 & 219.110 & 212.834 & -6.277 & Homogeneity & 212.83 & wt $\%$ oxide \\
\hline $\mathrm{Al} 2 \mathrm{O} 3$ & 3.184 & 3.166 & 3.184 & 3.788 & 0.604 & $\mathrm{Al} 2 \mathrm{O} 3$ & 3.79 & wt $\%$ oxide \\
\hline Low Conservation & 95 & 95 & 95 & 98.934 & 3.934 & Lo Conserv. & 98.93 & wt $\%$ oxide \\
\hline High Conservation & -105 & -105 & -105 & -98.934 & 6.066 & Hi Conserv. & 98.93 & wt $\%$ oxide \\
\hline Low Frit & 73.147 & 73.258 & 73.258 & 76.885 & 3.627 & Low Frit & 76.89 & wt $\%$ oxide \\
\hline High Frit & -81.853 & -81.742 & -81.742 & -76.885 & 4.857 & High Frit & 76.89 & wt $\%$ oxide \\
\hline $\mathrm{TiO} 2$ & -0.983 & -0.996 & -0.983 & -0.102 & 0.882 & $\mathrm{TiO} 2$ & 0.102 & wt $\%$ oxide \\
\hline $\mathrm{NaCl}$ & -1 & -1 & -1 & -0.041 & 0.959 & $\mathrm{NaCl}$ & 0.041 & wt $\%$ oxide \\
\hline $\mathrm{NaF}$ & -1 & -1 & -1 & -0.055 & 0.945 & $\mathrm{NaF}$ & 0.055 & wt $\%$ oxide \\
\hline $\mathrm{Cr} 2 \mathrm{O} 3$ & -0.273 & -0.276 & -0.273 & -0.085 & 0.188 & $\mathrm{Cr} 2 \mathrm{O} 3$ & 0.085 & wt $\%$ oxide \\
\hline $\mathrm{Na} 2 \mathrm{SO} 4$ & -0.59 & -0.59 & -0.59 & -0.037 & 0.553 & $\mathrm{Na} 2 \mathrm{SO} 4$ & 0.037 & wt $\%$ oxide \\
\hline $\mathrm{Cu}$ & -0.488 & -0.486 & -0.486 & -0.280 & 0.206 & $\mathrm{Cu}$ & 0.280 & wt $\%$ oxide \\
\hline $\mathrm{R} 2 \mathrm{O}$ & -18.641 & -18.656 & -18.641 & -17.040 & 1.601 & $\mathrm{R} 2 \mathrm{O}$ & 17.04 & wt $\%$ oxide \\
\hline
\end{tabular}


Note that from the results in Table 16 indicate that the homogeneity MAR is not satisfied for this composition (i.e., the MAR difference is negative) while the homogeneity PAR is satisfied by the derived value for homogeneity. Recall from Section 5.3.1 that there are two other options for satisfying the homogeneity constraint:

If $\underline{\mathrm{z}}$ satisfies the homogeneity PAR, i.e. if

$$
\underline{z a}_{\text {homog }}^{\mathrm{T}}-(210.9203) \geq 0
$$

then as long as one of the following is true, the homogeneity constraint is satisfied:

Option 1

$$
\begin{aligned}
& \underline{\mathrm{z}} \underline{\mathrm{a}}_{\mathrm{Al}_{2} \mathrm{O}_{3}}^{\mathrm{T}}-3.0-\mathrm{t}_{\alpha}(\mathrm{m}-1) \sqrt{\frac{\underline{\mathrm{a}}_{\mathrm{Al}_{2} \mathrm{O}_{3}} \mathbf{S} \underline{\mathrm{a}}_{\mathrm{Al}_{2} \mathrm{O}_{3}}^{\mathrm{T}}}{\mathrm{n}}} \geq 0 \\
& \underline{\mathrm{z}} \underline{\mathrm{a}}_{\text {alkali }}^{\mathrm{T}}-(-19.3)-\mathrm{t}_{\alpha}(\mathrm{m}-1) \sqrt{\frac{\underline{\mathrm{a}}_{\text {alkali }} \mathbf{S} \underline{\mathrm{a}}_{\text {alkali }}^{\mathrm{T}}}{\mathrm{n}}} \geq 0
\end{aligned}
$$

where the vector and offset associated with the alkali content of the composition are provided in Table 7.

Option 2

$$
\underline{\mathrm{z}^{2}}{ }_{\mathrm{Al}_{2} \mathrm{O}_{3}}^{\mathrm{T}}-4.0-\mathrm{t}_{\alpha}(\mathrm{m}-1) \sqrt{\frac{\underline{\mathrm{a}}_{\mathrm{Al}_{2} \mathrm{O}_{3}} \mathbf{S}_{\underline{\mathrm{a}}_{2} \mathrm{O}_{3}}^{\mathrm{T}}}{\mathrm{n}}} \geq 0
$$

The derived value for the alumina constraint is 3.788, and this value is greater than 3.0 plus measurement uncertainty (i.e., the MAR limit for the alumina constraint) which equals 3.184 (i.e., the measurement uncertainty is 0.184 ). Also, note that this implies that 4.0 plus the measurement uncertainty would be $4.0+0.184=4.184$. Since the derived value (3.788) is not greater than 4.184 the second option is not satisfied.

Also, note that the derived value -17.040 for the $\mathrm{R}_{2} \mathrm{O}$ (sum of alkali) constraint is greater than its MAR limit of -18.641 (i.e., the alkali MAR is satisfied). Since both parts of Option 1 are met, the homogeneity constraint is satisfied.

Also, recall that for compositions with sufficiently high (4.43 wt $\%$ plus measurement uncertainty) levels of $\mathrm{Al}_{2} \mathrm{O}_{3}$, the low frit constraint can be omitted from consideration during the acceptability assessment (see Section 5.3.2). For the current sample calculation, the $\mathrm{Al}_{2} \mathrm{O}_{3}$ concentration is not high enough to support this approach; however, the low frit constraint's MAR limit is met so that all of these constraints are satisfied, leaving only the $\mathrm{T}_{\mathrm{L}}$ constraint. 


\section{Revision 4}

The nonlinearity of the $\mathrm{T}_{\mathrm{L}}$ model (and corresponding constraint) forces it to be handled in a manner that differs from way that was just used for the other constraints. First of all, Using the molar oxide concentrations (z.) from Table 13 and the $\mathrm{f}$ (speciations) from Table 12, compute the estimated $\mathrm{T}_{\mathrm{L}}$ in ${ }^{\circ} \mathrm{C}$ for the SME batch using:

$$
\frac{1}{\mathrm{~T}_{\mathrm{L}}(\mathrm{K})}=\ln \left\{\left(\mathrm{M}_{2}\right)^{\mathrm{a}}\left(\mathrm{M}_{1}\right)^{\mathrm{b}}\left(\mathrm{M}_{\mathrm{T}}\right)^{\mathrm{c}}\right\}+\mathrm{d}=\mathrm{a} \ln \left(\mathrm{M}_{2}\right)+\mathrm{b} \ln \left(\mathrm{M}_{1}\right)+\mathrm{c} \ln \left(\mathrm{M}_{\mathrm{T}}\right)+\mathrm{d}
$$

or

$$
\mathrm{T}_{\mathrm{L}}\left({ }^{\mathrm{o}} \mathrm{C}\right)=\left\{\mathrm{a} \ln \left(\mathrm{M}_{2}\right)+\mathrm{b} \ln \left(\mathrm{M}_{1}\right)+\mathrm{c} \ln \left(\mathrm{M}_{\mathrm{T}}\right)+\mathrm{d}\right\}^{-1}-273
$$

where

$$
\begin{aligned}
& \Sigma_{\mathrm{MT}} \equiv \phi_{\mathrm{T}, \mathrm{SiO}_{2}} \mathrm{z}_{\mathrm{SiO}_{2}}+\phi_{\mathrm{T}, \mathrm{Al}_{2} \mathrm{O}_{3}} \mathrm{z}_{\mathrm{Al}_{2} \mathrm{O}_{3}}+\phi_{\mathrm{T}, \mathrm{Fe}_{2} \mathrm{O}_{3}} \mathrm{z}_{\mathrm{Fe}_{2} \mathrm{O}_{3}}
\end{aligned}
$$

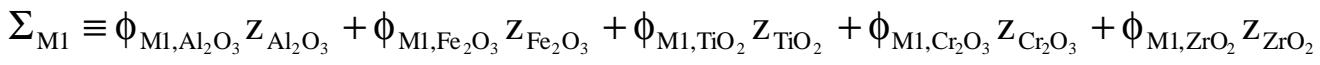

$$
\begin{aligned}
& +\phi_{\mathrm{M} 1, \mathrm{NiO}} \mathrm{z}_{\mathrm{NiO}}+\phi_{\mathrm{M} 1, \mathrm{MgO}} \mathrm{z}_{\mathrm{MgO}}+\phi_{\mathrm{M} 1, \mathrm{MnO}} \mathrm{z}_{\mathrm{MnO}} \\
& \Sigma_{\mathrm{M} 2} \equiv \phi_{\mathrm{M} 2, \mathrm{NiO}} \mathrm{Z}_{\mathrm{NiO}}+\phi_{\mathrm{M} 2, \mathrm{MgO}} \mathrm{Z}_{\mathrm{MgO}}+\phi_{\mathrm{M} 2, \mathrm{MnO}} \mathrm{Z}_{\mathrm{MnO}}+\phi_{\mathrm{M} 2, \mathrm{CaO}} \mathrm{Z}_{\mathrm{CaO}}
\end{aligned}
$$

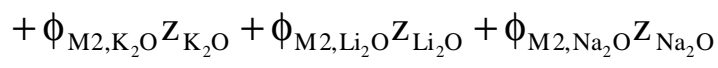

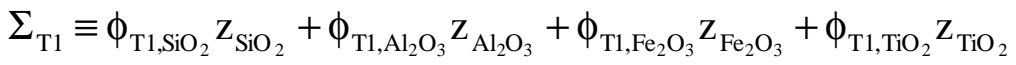

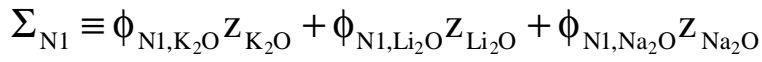

and

$$
\mathrm{M}_{2} \equiv \frac{\Sigma_{\mathrm{M} 2}}{\Sigma}, \mathrm{M}_{1} \equiv \frac{\Sigma_{\mathrm{M} 1}}{\Sigma}, \mathrm{M}_{\mathrm{T}} \equiv \frac{\Sigma_{\mathrm{MT}}}{\Sigma} \text {, and } \Sigma \equiv \Sigma_{\mathrm{M} 2}+\Sigma_{\mathrm{M} 1}+\Sigma_{\mathrm{MT}}+\Sigma_{\mathrm{T} 1}+\Sigma_{\mathrm{N} 1}
$$

The predicted $\mathrm{T}_{\mathrm{L}}$ is $978.872^{\circ} \mathrm{C}$.

The assessment of the SME composition against the TL PAR limit (in 1/TL(K)) can be conducted (as discussed in Section 5.5.1) using

$$
\begin{aligned}
& \ln \left\{\left(\mathrm{M}_{2}\right)^{-0.000260}\left(\mathrm{M}_{1}\right)^{-0.000566}\left(\mathrm{M}_{\mathrm{T}}\right)^{-0.000153}\right\}-0.00144 \\
& -\left(2.28 \times 10^{-5}\right) \sqrt{\mathrm{pF}_{2 \alpha}(\mathrm{p}, \mathrm{N}-\mathrm{p})} \sqrt{\left[\begin{array}{rrrr}
105 & -126.56 & -309.14 & -162.47 \\
-126.56 & 154.22 & 371.50 & 194.98 \\
\xi 309.14 & 371.50 & 913.84 & 473.73 \\
-162.47 & 194.98 & 473.73 & 265.64
\end{array}\right]^{-1} \geq 7.56 \times 10^{-4} \mathrm{~K}^{-1}}
\end{aligned}
$$

where $\xi$ is defined to be the vector (i.e., $\left[1 \ln \left(\mathrm{M}_{2}\right) \ln \left(\mathrm{M}_{1}\right) \ln \left(\mathrm{M}_{\mathrm{T}}\right)\right]$ ) of values at which to predict $\left(1 / \mathrm{T}_{\mathrm{L}}\right), \mathrm{p}=4$, and $\mathrm{n}=135, \mathrm{a}=0.05$ (or 5\%), and thus, $\mathrm{F}_{0.10}(4,131)=2.0014$ Thus, for the given SME composition, compute the values of $\ln \left(\mathrm{M}_{2}\right), \ln \left(\mathrm{M}_{1}\right)$, and $\ln \left(\mathrm{M}_{\mathrm{T}}\right)$ and see if this inequality is satisfied. If so, the composition is in the $\mathrm{T}_{\mathrm{L}} \mathrm{PAR}$. 
For the composition of Table 13, the PAR limit is $1036.5265^{\circ} \mathrm{C}$. Note that the predicted $\mathrm{T}_{\mathrm{L}}$ of $978.872^{\circ} \mathrm{C}$ is less than (and thus, satisfies) this PAR limit.

Next, the $\mathrm{T}_{\mathrm{L}}$ MAR limits for the historical (absolute error model) and the current (relative-error model) compositions are computed as directed in Section 5.5.2 yielding:

$$
\mathrm{MAR}_{\text {historical }}=1012.973^{\circ} \mathrm{C} \quad \text { and } \quad \mathrm{MAR}_{\text {current }}=1010.569^{\circ} \mathrm{C}
$$

Thus, the MAR limit is the smaller of the two or $1010.569^{\circ} \mathrm{C}$, and since the predicted $\mathrm{T}_{\mathrm{L}}$ of $978.872{ }^{\circ} \mathrm{C}$ is less than this value, the composition satisfies the $\mathrm{T}_{\mathrm{L}} \mathrm{MAR}$.

Thus, the SME composition of Table 12 satisfies all of the appropriate MAR limits at the appropriate confidence levels and thus, would be considered acceptable.

\section{Conclusions}

This document establishes the technical basis for DWPF's Product Composition Control System (PCCS), a statistical process control system for monitoring SME batches and for supporting acceptability decisions at this production hold-point for the facility. Using chemical composition measurements derived from SME samples as input, the system assesses the acceptability of the SME batch against appropriate process, product quality, and solubility constraints after accounting for applicable uncertainties (those due to property models, when such models are used, and those due to the sample measurements themselves).

This report meticulously details the measurement inputs, the property models, and the statistical methods for dealing with their uncertainties in meeting the constraints imposed on DWPF operations. The system implements each of the constraints associated with product quality (i.e., the durability of the wasteform produced by the DWPF) at the required $95 \%$ confidence level. The confidence levels for meeting the other constraints (i.e., those associated with processability and solubility), while not mandated to be at $95 \%$, were developed to this confidence level in this paper. However, the system does allow flexibility, at management's discretion, in the confidence levels associated with these non-waste-affecting constraints. 


\section{REFERENCES}

[1] Jantzen, C.M, Pickett, J.B., Brown, K.G., Edwards, T.B., and Beam, D.C. "Process/Product Models for the Defense Waste Processing Facility (DWPF): Part I. Predicting Glass Durability from Composition Using a Thermodynamic Hydration Energy Reaction Model (THERMO)," WSRC-TR-93-672, Rev. 1, August 1, 1995.

[2] Office of Environmental Management, Waste Acceptance Product Specifications for Vitrified High-Level Waste Forms, Revision 2, USDOE Document EM-WAPS, U.S. Department of Energy, Germantown, MD, 1996.

[3] ASTM C1285-97, "Standard Test Methods for Determining Chemical Durability of Nuclear Waste Glasses: The Product Consistency Test (PCT)," 1997.

[4] Edwards, T.B. and K.G. Brown "Evaluating the Glasses Batched for the Tank 42 Variability Study (U)," SRT-SCS-98-017, Revision 0, May 11, 1998.

[5] Brown, K.G. and Edwards, T.B. "Definition of the DWPF Homogeneity Constraint," WSRC-TR-95-0060, January 31, 1995.

[6] Brown, K. G. "Relaxation of the Lower Frit Loading Constraint for DWPF Process Control (U)," WSRC-RP-99-00355, May 6, 1999.

[7] Smith, M. E. "Reevaluation of DWPF High Viscosity Constraint: SRTC ITS Position," SRT-GFM-99-0011, April 30, 1999.

[8] Brown, K. G. "Changes Made to the DWPF PCCS Spreadsheet (U)," SRTCGPD-2002-00059, May 16, 2002.

[9] Plodinec, M.J. and Wilds, G.W. "Long Term Waste Management Progress Report-Role of $\mathrm{TiO}_{2}$ in SRP Waste Glass," DPST-78-358, May 19, 1978.

[10] Personal Communication from C.M. Jantzen of SRTC to K.G. Brown.

[11] Bickford, D.F., Hrma, P., Bowen, B.W., and Smith, P.K. "Control of Radioactive Waste Glass Melters: Parts 1\&2," DP-MS-86-217AI and AII (April 1987).

[12] Bickford, D.F. and Jantzen, C.M. "Inhibitor Limits for Washed Precipitate Based on Glass Quality and Solubility Limits," DPST-86-546, October 6, 1986.

[13] Ramsey, W.G. and Schumacher, R.F. "Effects of Formate and Nitrate Concentration on Waste Glass Redox at High Copper Concentration," WSRCTR-92-484, October 23, 1992. 
[14] Miller, Jr., R.G. Simultaneous Statistical Inference, Second Edition, SpringerVerlag, New York, 1981.

[15] Brown, K. G. "New Limits for the DWPF Product Composition Control System (PCCS) (U)," SRTC-GPD-2002-00054, May 2, 2002.

[16] Jantzen, C.M. "The Relationship Between Glass Viscosity and Composition: A First Principles Model for Vitrification of Nuclear Waste," WSRC-MS-90-41, April 1991.

[17] Jantzen, C.M. "Process/Product Models for the Defense Waste Processing Facility (DWPF) Glass: Part II. Viscosity, Resistivity, Composition Relations," (in preparation).

[18] Scheffé, H. The Analysis of Variance, John Wiley \& Sons, New York, 1959.

[19] Draper, N.R. and Smith, H. Applied Regression Analysis, Second Edition John Wiley \& Sons, New York, 1981.

[20] Brown, K. G., C. M. Jantzen, G. Ritzhaupt, "Relating Liquidus Temperature to Composition for Defense Waste Processing Facility (DWPF) Process Control (U),"WSRC-TR-2001-00520, Revision 0, October 25, 2001.

[21] Schrieber, H.D. and Hockman, A.L. "Redox Chemistry in Candidate Glasses for Nuclear Waste Immobilization," J. Amer. Ceram. Soc., 70[8], 591-594 (1987).

[22] Graybill, F.A. An Introduction to Linear Statistical Models, Vol I, McGrawHill, New York, 1961, Thm. 3.6, p56.

[23] Morrison, D.F. Multivariate Statistical Methods, Second Edition, McGraw-Hill, New York, 1976, p30.

[24] Reeve, C.P. "Statistical Analysis of DWPF Prototypic Tests: SME Feed," SCSASG-93-0050, 1993.

[25] Reeve, C.P. "PCCS Covariance Matrices Based on Prototypic Tests," SCS-ASG93-0048, June 4, 1993. 
WSRC-TR-95-000364

Revision 4

This page intentionally left blank. 


\section{Appendix A. Chemical Composition Measurements of SME Samples}

This appendix identifies the measurements derived from the SME samples and establishes a unit of measurement for component concentrations that is to be used in PCCS calculations, and presents the necessary information for handling the measurement (sampling/ preparation/and analytical) errors or uncertainties associated with the SME sample results.

\section{SME Sample Measurements}

The acceptability determination for a SME batch by PCCS is initiated by the entry of measurements from $n$ (where $n \geq 4$ ) samples taken from the contents of the SME. The measurements generated from each of the SME samples are outlined in Table A1. As noted in this table, measurements are provided for the physical properties of total weight percent (wt\%) solids, the calcined wt\% solids, and specific gravity (in $\mathrm{g} / \mathrm{mL}$ ). The remaining rows of Table A1 indicate the components that are used to represent the chemical composition of the sample. This is the largest set of components deemed necessary to capture the information needed for waste solubility constraints as well as that needed to cover components whose concentrations in the DWPF glass product would be expected to exceed $0.5 \%$ by weight [2]. The concentration measurement for each cation reported in Table A1 is given in mass weight percent (wt\%).

Table A1. Measurements from Each SME Sample

\begin{tabular}{|c|c|c|c|c|c|c|}
\hline $\begin{array}{l}\text { Solids } \\
\text { Element/ } \\
\text { anion }\end{array}$ & & $\begin{array}{c}\text { Unit of } \\
\text { Measure } \\
\text { wt } \%\end{array}$ & $\begin{array}{l}\text { Calcined Solids } \\
\text { Element/ } \\
\text { anion }\end{array}$ & $\begin{array}{c}\text { Unit of } \\
\text { Measure } \\
\text { wt } \%\end{array}$ & $\begin{array}{l}\text { Specific Gravity } \\
\text { Element/ } \\
\text { anion }\end{array}$ & $\begin{array}{l}\text { Unit of } \\
\text { Measure } \\
\mathrm{g} / \mathrm{mL}\end{array}$ \\
\hline & $\mathrm{Al}$ & $\mathrm{wt} \%$ & $\mathrm{Mg}$ & $\mathrm{wt} \%$ & $\mathrm{Y}$ & wt $\%$ \\
\hline & B & wt $\%$ & $\mathrm{Mn}$ & $\mathrm{wt} \%$ & $\mathrm{Zn}$ & $\mathrm{wt} \%$ \\
\hline & $\mathrm{Ba}$ & $\mathrm{wt} \%$ & Mo & $\mathrm{wt} \%$ & $\mathrm{Zr}$ & $\mathrm{wt} \%$ \\
\hline & $\mathrm{Ca}$ & $\mathrm{wt} \%$ & $\mathrm{Na}$ & wt $\%$ & $\mathrm{Cl}$ & ppm \\
\hline & $\mathrm{Ce}$ & wt $\%$ & $\mathrm{Nd}$ & $\mathrm{wt} \%$ & $\mathrm{~F}$ & ppm \\
\hline & $\mathrm{Cr}$ & $\mathrm{wt} \%$ & $\mathrm{Ni}$ & $\mathrm{wt} \%$ & $\mathrm{HCOO}$ & ppm \\
\hline & $\mathrm{Cs}$ & wt $\%$ & $\mathrm{~Pb}$ & wt $\%$ & $\mathrm{NO}_{2}$ & ppm \\
\hline & $\mathrm{Cu}$ & $\mathrm{wt} \%$ & $\mathrm{Si}$ & $\mathrm{wt} \%$ & $\mathrm{NO}_{3}$ & ppm \\
\hline & $\mathrm{Fe}$ & $\mathrm{wt} \%$ & Th & $\mathrm{wt} \%$ & $\mathrm{PO}_{4}$ & ppm \\
\hline & $\mathrm{K}$ & $\mathrm{wt} \%$ & $\mathrm{Ti}$ & $\mathrm{wt} \%$ & $\mathrm{SO}_{4}$ & ppm \\
\hline & $\mathrm{La}$ & $\mathrm{wt} \%$ & $\mathrm{U}$ & $\mathrm{wt} \%$ & TOC & ppm \\
\hline & $\mathrm{Li}$ & $\mathrm{wt} \%$ & & & & \\
\hline
\end{tabular}

The concentration of each anion, i, necessary for DWPF process control (i.e., $\mathrm{Cl}^{-} \rightarrow$ $\mathrm{NaCl}, \mathrm{F}^{-} \rightarrow \mathrm{NaF}, \mathrm{SO}_{4}{ }^{-} \rightarrow \mathrm{Na}_{2} \mathrm{SO}_{4}$, and $\mathrm{PO}_{4}{ }^{-3} \rightarrow \mathrm{P}_{2} \mathrm{O}_{5}$ ) is reported in terms of parts per million (ppm), i.e., $\mathrm{g} i / 10^{6} \mathrm{~g}$ sample or $\mathrm{p}_{\mathrm{i}}$. The sample measurement is converted from the 


\section{Revision 4}

sample basis (i.e., ppm or $\mathrm{p}_{\mathrm{i}}$ ) to the corresponding elemental analysis basis (i.e., $\mathrm{g} \mathrm{i} / 100 \mathrm{~g}$ glass or $\mathrm{x}_{\mathrm{i}}$ ) using the formula:

$$
\mathrm{x}_{\mathrm{i}} \equiv \frac{1}{100 \omega_{\mathrm{c}}} \mathrm{p}_{\mathrm{i}}
$$

where $\omega_{c}$ is the measured calcined wt $\%$ solids for the sample and $x_{i}$ for analyte $i$ is in $g$ i/100g glass. This also indicates that the error associated with these converted compositions, the $x_{i}$ 's, have contributions from both $p_{i}$ and $\omega_{c}$. This error can be estimated via propagation of error techniques. However, since the contributions of these anions to the non-solubility constraints (e.g., durability, liquidus temperature, etc.) is rather small, only the error in the measured anion concentration is used in PCCS for DWPF process control.

\section{Unit of Measure for Compositions}

As the reader progresses through body of this report, it will become apparent, if it is not already, that there is a need to establish a consistent basis (i.e., unit of measurement) for the SME sample results to facilitate their use in PCCS. The unit of measurement selected for this purpose is molar oxide concentration using:

$$
\mathrm{z}_{\text {oxide }} \equiv \frac{\mathrm{x}_{\text {oxide }}}{\mathrm{M}_{\text {oxide }}}
$$

where $\mathrm{M}_{\text {oxide }}$ is the molecular weight of the oxide and $\mathrm{x}_{\text {oxide }}$ is the mass weight percent of the oxide. Table A2 provides the associations between the element reported as part of the SME sample results and the corresponding oxide including the gravimetric factor and the molecular weight.

Note that several of the entries in Table A2 actually play no role in the SME acceptability decision: $\mathrm{HCOO}, \mathrm{NO}_{2}, \mathrm{NO}_{3}$, and TOC (total organic carbon). That is, these components are not involved in any of the calculations associated with any of the constraints (process, product, or solubility) imposed on the DWPF's operation. 
Table A2. Elemental Measurements with Corresponding Oxides, Gravimetric Factors, and Molecular Weights

\begin{tabular}{|c|c|c|c|c|}
\hline $\begin{array}{l}\text { Element/ } \\
\text { anion }\end{array}$ & $\begin{array}{c}\text { Measured } \\
\text { as }\end{array}$ & $\begin{array}{c}\text { Gravimetric } \\
\text { Factor }\end{array}$ & $\begin{array}{c}\text { Corresponding } \\
\text { Oxide }\end{array}$ & $\begin{array}{r}\text { Molecular } \\
\text { Weight }\end{array}$ \\
\hline Al & wt $\%$ & 1.8895 & $\mathrm{Al}_{2} \mathrm{O}_{3}$ & 101.9612 \\
\hline $\mathrm{B}$ & $\mathrm{wt} \%$ & 3.2199 & $\mathrm{~B}_{2} \mathrm{O}_{3}$ & 69.6202 \\
\hline $\mathrm{Ba}$ & $\mathrm{wt} \%$ & 1.1165 & $\mathrm{BaO}$ & 153.3394 \\
\hline $\mathrm{Ca}$ & wt $\%$ & 1.3992 & $\mathrm{CaO}$ & 56.0794 \\
\hline $\mathrm{Ce}$ & wt $\%$ & 1.1713 & $\mathrm{Ce}_{2} \mathrm{O}_{3}$ & 328.2382 \\
\hline $\mathrm{Cr}$ & wt $\%$ & 1.4616 & $\mathrm{Cr}_{2} \mathrm{O}_{3}$ & 151.9902 \\
\hline Cs & $\mathrm{wt} \%$ & 1.0602 & $\mathrm{Cs}_{2} \mathrm{O}$ & 281.8094 \\
\hline $\mathrm{Cu}$ & wt $\%$ & 1.2520 & $\mathrm{CuO}$ & 75.54390775 \\
\hline $\mathrm{Fe}$ & wt $\%$ & 1.4297 & $\mathrm{Fe}_{2} \mathrm{O}_{3}$ & 159.6922 \\
\hline $\mathrm{K}$ & wt $\%$ & 1.2046 & $\mathrm{~K} 2 \mathrm{O}$ & 94.2034 \\
\hline $\mathrm{La}$ & wt $\%$ & 1.1728 & $\mathrm{La}_{2} \mathrm{O}_{3}$ & 325.8182 \\
\hline $\mathrm{Li}$ & $\mathrm{wt} \%$ & 2.1529 & $\mathrm{Li}_{2} \mathrm{O}$ & 29.8774 \\
\hline $\mathrm{Mg}$ & $\mathrm{wt} \%$ & 1.6581 & $\mathrm{MgO}$ & 40.3114 \\
\hline $\mathrm{Mn}$ & $\mathrm{wt} \%$ & 1.2912 & $\mathrm{MnO}$ & 70.9374 \\
\hline Mo & wt $\%$ & 1.5003 & $\mathrm{MoO}_{3}$ & 143.9382 \\
\hline $\mathrm{Na}$ & wt $\%$ & 1.3480 & $\mathrm{Na}_{2} \mathrm{O}$ & 61.979 \\
\hline $\mathrm{Nd}$ & wt $\%$ & 1.1664 & $\mathrm{Nd}_{2} \mathrm{O}_{3}$ & 336.4782 \\
\hline $\mathrm{Ni}$ & $\mathrm{wt} \%$ & 1.2725 & $\mathrm{NiO}$ & 74.7094 \\
\hline $\mathrm{Pb}$ & $\mathrm{wt} \%$ & 1.0772 & $\mathrm{PbO}$ & 223.1894 \\
\hline $\mathrm{Si}$ & wt $\%$ & 2.1393 & $\mathrm{SiO}_{2}$ & 60.0848 \\
\hline Th & $\mathrm{wt} \%$ & 1.1379 & $\mathrm{ThO}_{2}$ & 264.0368 \\
\hline $\mathrm{Ti}$ & $\mathrm{wt} \%$ & 1.6680 & $\mathrm{TiO}_{2}$ & 79.8988 \\
\hline $\mathrm{U}$ & $\mathrm{wt} \%$ & 1.1792 & $\mathrm{U}_{3} \mathrm{O}_{8}$ & 842.0852 \\
\hline $\mathrm{Y}$ & $\mathrm{wt} \%$ & 1.2699 & $\mathrm{Y}_{2} \mathrm{O}_{3}$ & 225.8082 \\
\hline $\mathrm{Zn}$ & $\mathrm{wt} \%$ & 1.2448 & $\mathrm{ZnO}$ & 81.3694 \\
\hline $\mathrm{Zr}$ & wt $\%$ & 1.3508 & $\mathrm{ZrO}_{2}$ & 123.2188 \\
\hline $\mathrm{Cl}$ & ppm & 1.6485 & $\mathrm{NaCl}$ & 58.4428 \\
\hline $\mathrm{F}$ & ppm & 2.2101 & $\mathrm{NaF}$ & 41.9882 \\
\hline $\mathrm{HCOO}$ & ppm & Not Used & $\mathrm{HCCO}$ & Not Used \\
\hline $\mathrm{NO}_{2}$ & $\mathrm{ppm}$ & Not Used & $\mathrm{NO}_{2}$ & Not Used \\
\hline $\mathrm{NO}_{3}$ & $\mathrm{ppm}$ & Not Used & $\mathrm{NO}_{3}$ & Not Used \\
\hline $\mathrm{PO}_{4}$ & ppm & 0.7473 & $\mathrm{P}_{2} \mathrm{O}_{5}$ & 141.9446 \\
\hline $\mathrm{SO}_{4}$ & ppm & 1.4790 & $\mathrm{Na}_{2} \mathrm{SO}_{4}$ & 142.0412 \\
\hline TOC & ppm & Not Used & \multicolumn{2}{|c|}{ TOC is not used in PCCS } \\
\hline
\end{tabular}

The components representing the measured sample compositions in the order used in PCCS is provided in Table A3 and this vector is represented by $\underline{z}$ for each sample.

Table A3. Components Representing SME Composition in the Order Used by PCCS

\begin{tabular}{|cccccccccccc|}
\hline Order & 1 & 2 & 3 & 4 & 5 & 6 & 7 & 8 & 9 & 10 & 11 \\
Oxide & $\mathrm{Al}_{2} \mathrm{O}_{3}$ & $\mathrm{~B}_{2} \mathrm{O}_{3}$ & $\mathrm{BaO}$ & $\mathrm{HCOO}$ & $\mathrm{CaO}$ & $\mathrm{Ce}_{2} \mathrm{O}_{3}$ & $\mathrm{NaCl}$ & $\mathrm{Cr}_{2} \mathrm{O}_{3}$ & $\mathrm{Cs}_{2} \mathrm{O}$ & $\mathrm{CuO}$ & $\mathrm{NaF}$ \\
\hline Order & 12 & 13 & 14 & 15 & 16 & 17 & 18 & 19 & 20 & 21 & 22 \\
Oxide & $\mathrm{Fe}_{2} \mathrm{O}_{3}$ & $\mathrm{~K}_{2} \mathrm{O}$ & $\mathrm{La}_{2} \mathrm{O}_{3}$ & $\mathrm{Li} 2 \mathrm{O}$ & $\mathrm{MgO}$ & $\mathrm{MnO}$ & $\mathrm{MoO}_{3}$ & $\mathrm{NO}_{2}$ & $\mathrm{NO}_{3}$ & $\mathrm{Na}_{2} \mathrm{O}^{2}$ & $\mathrm{Na}_{2} \mathrm{SO}_{4}$ \\
\hline Order & 23 & 24 & 25 & 26 & 27 & 28 & 29 & 30 & 31 & 32 & 33 \\
Oxide & $\mathrm{Nd}_{2} \mathrm{O}_{3}$ & $\mathrm{NiO}$ & $\mathrm{P}_{2} \mathrm{O}_{5}$ & $\mathrm{PbO}$ & $\mathrm{SiO}_{2}$ & $\mathrm{ThO}_{2}$ & $\mathrm{TiO}_{2}$ & $\mathrm{U}_{3} \mathrm{O}_{8}$ & $\mathrm{Y}_{2} \mathrm{O}_{3}$ & $\mathrm{ZnO}_{2}$ & $\mathrm{ZrO}_{2}$ \\
\hline
\end{tabular}




\section{Appendix B. Measurement Uncertainty for SME Samples}

Appendix B presents the necessary information for handling the measurement (sampling/ preparation/and analytical) errors or uncertainties associated with SME sample results.

\section{Historical Information on Measurement Uncertainty}

One type of uncertainty that must be addressed, as part of the SME acceptability decision, is measurement uncertainty associated with the average chemical composition, $\underline{z}$, for each sample. (See Table A3 in Appendix A for a listing of all of the components of $\underline{z}$ ). Here measurement includes the processes of sampling and sample preparation as well as actual measurement.

To quantify the measurement uncertainty, the errors in the measurements comprising $\underline{z}$ are presumed to be Gaussian. Given q important elements, ${ }^{*}$ the measurement uncertainty is q-variate Gaussian with true mean $\underline{0}$ and covariance matrix $\Sigma$. Thus, by not unreasonable presumption, the measurement $\underline{z}$ is also multivariate normal with true mean $\underline{\mu}$ and the same covariance matrix, and thus obeys the probability density:

$$
f(\underline{z}) \equiv\left[(2 \pi)^{q}|\Sigma|\right]^{\frac{1}{2}} \exp \left[\left(-\frac{1}{2}\right)(z-\underline{\mu}) \Sigma^{-1}(\underline{z}-\underline{\mu})^{T}\right]
$$

Presuming the errors in the concentrations of individual constituents to be multivariate Gaussian enables the traditional methods of multivariate normal theory to apply. Let $\underline{z}$ be a current SME batch composition measurement, which estimates its underlying true composition $\underline{\mu}$. If there are $\mathrm{q}$ important constituents, $\underline{\mathrm{z}}$ is a 1xq array of measured molar oxide concentrations (i.e., mole oxide $/ 100 \mathrm{~g}$ glass) of the constituent oxides:

$$
\mathrm{z} \equiv\left[\mathrm{z}_{0}, \mathrm{z}_{1}, \ldots, \mathrm{z}_{\mathrm{q}-1}\right]
$$

Let $\mathbf{S}_{\mathrm{m}}$ be a covariance matrix estimate from an historic sample of $\mathrm{m}$ such measurements. ${ }^{\dagger} \mathbf{S}_{\mathrm{m}}$ consists of the variances within and covariances between the $q$ individual oxides:

$$
\mathbf{S}_{\mathrm{m}} \equiv\left[\begin{array}{cccc}
\mathrm{s}_{0,0} & \mathrm{~s}_{0,1} & \ldots & \mathrm{s}_{0, \mathrm{q}-1} \\
\mathrm{~s}_{0,1} & \mathrm{~s}_{1,1} & \ldots & \mathrm{s}_{1, \mathrm{q}-1} \\
\ldots & \ldots & \ldots & \ldots \\
\mathrm{s}_{0, \mathrm{q}-1} & \mathrm{~s}_{1, \mathrm{q}-1} & \ldots & \mathrm{s}_{\mathrm{q}-1, \mathrm{q}-1}
\end{array}\right]
$$

That is, of such type and present in such amount as to have non-negligible effect on the properties under consideration.

$\dagger \quad$ Thus $\mathbf{S}_{\mathrm{m}}$ is developed from data excluding the measurements for the current SME batch and possibly other recent ones. The information used to compute $\mathbf{S}_{\mathrm{m}}$ can be updated if necessary. 
where the $s_{i, j}$ are the historic sample variances $(i=j)$ and covariances $(i \quad j)$. However the available covariance information for the DWPF is based upon elemental information, i.e., $\underline{x}$. This covariance information consists of the variances within and the covariances between the $q$ individual elements and is contained in the matrix $\mathbf{E}_{\mathrm{m}}$ :

$$
\mathbf{E}_{\mathrm{m}} \equiv\left[\begin{array}{cccc}
\mathrm{e}_{0,0} & \mathrm{e}_{0,1} & \ldots & \mathrm{e}_{0, \mathrm{q}-1} \\
\mathrm{e}_{0,1} & \mathrm{e}_{1,1} & \ldots & \mathrm{e}_{1, \mathrm{q}-1} \\
\ldots & \ldots & \ldots & \ldots \\
\mathrm{e}_{0, \mathrm{q}-1} & \mathrm{e}_{1, \mathrm{q}-1} & \cdots & \mathrm{e}_{\mathrm{q}-1, \mathrm{q}-1}
\end{array}\right]
$$

In $\mathbf{E}_{\mathrm{m}}$, the $\mathrm{e}_{\mathrm{i}, \mathrm{j}}$ are the historic sample elemental variances and covariances:

$$
e_{i, j}=\frac{1}{m-1} \sum_{k=0}^{m-1}\left(x_{i, k}-\bar{x}_{i}\right)\left(x_{j, k}-\bar{x}_{j}\right) \text { where } \bar{x}_{i}=\frac{1}{m} \sum_{k=0}^{m-1} x_{i, k}
$$

and $\mathrm{x}_{\mathrm{i}, \mathrm{k}}$ is the elemental mass concentration for the $\mathrm{k}^{\text {th }}$ element from the $\mathrm{i}^{\text {th }}$ sample. This covariance matrix may also be defined based upon the correlation matrix, $\mathbf{C}_{\mathrm{m}}$, which consists of the pair-wise correlations between the q individual elements:

$$
\left.\mathbf{C}_{m} \equiv \mid \begin{array}{cccc}
\rho_{0,0} & \rho_{0,1} & \cdots & \rho_{0, q-1} \\
\rho_{0,1} & \rho_{1,1} & \cdots & \rho_{1, q}-1 \\
\cdots & \cdots & \cdots & \cdots \\
\rho_{0, q-1} & \rho_{1, q-1} & \cdots & \rho_{q-1, q}-1
\end{array}\right] \text { where } \rho_{i, j}=\frac{e_{i, j}}{\sqrt{e_{i, i} e_{j, j}}}
$$

Now if $\left(\mathrm{r}_{\mathrm{m}}\right)_{\mathrm{i}}$ represents the relative standard deviation for the $\mathrm{i}^{\text {th }}$ element based upon historical information, then:

$$
\left(r_{m}\right)_{i}=\frac{\sqrt{e_{i, i}}}{\bar{x}_{i}}
$$

Therefore, the $\mathrm{i}, \mathrm{j}^{\text {th }}$ member of the historic elemental covariance matrix, $\mathbf{E}_{\mathrm{m}}$, is given by:

$$
\left.\left(\mathbf{E}_{m}\right)_{i, j}=e_{i, j}=\left[\left(r_{m}\right)_{i}^{-} \bar{x}_{i}\right]\left(r_{m}\right)_{j} \bar{x}_{j}\right] p_{i, j} .
$$

Fortunately the elemental covariance matrix, $\mathbf{E}_{\mathrm{m}}$, can be easily transformed to $\mathbf{S}_{\mathrm{m}}$ for SME acceptability determination. The covariance between the $i$ and $j^{\text {th }}$ elemental concentrations is defined to be:

$$
e_{i, j} \equiv E\left(x_{i} x_{j}\right)-E\left(x_{i}\right) E\left(x_{j}\right)
$$




\section{Revision 4}

where $\mathrm{E}(\mathrm{x})$ is the expected value or expectation of the parameter $\mathrm{x}$. Similarly, the covariance between the $\mathrm{i}$ and $\mathrm{j}$ th mass oxide concentrations is:

$$
s_{i, j} \equiv E\left(z_{i} z_{j}\right)-E\left(z_{i}\right) E\left(z_{j}\right)
$$

The mass oxide concentration is a simple function of the elemental mass concentration:

$$
\mathrm{z}_{\mathrm{i}} \equiv \frac{\gamma_{\mathrm{i}}}{\mathrm{M}_{\mathrm{i}}} \mathrm{x}_{\mathrm{i}}
$$

where $\gamma_{i}$ is the gravimetric factor converting from mass element to corresponding oxide and $\mathrm{M}_{\mathrm{i}}$ is the molecular weight of the corresponding oxide. Thus

$$
s_{i, j} \equiv E\left[\left(\frac{\gamma_{i}}{M_{i}} x_{i}\right)\left(\frac{\gamma_{j}}{M_{j}} x_{j}\right)\right]-E\left(\frac{\gamma_{i}}{M_{i}} x_{i}\right) E\left(\frac{\gamma_{j}}{M_{j}} x_{j}\right)
$$

or since the expected value of a constant (e.g., $\gamma_{i}$ or $M_{i}$ ) is simply the value of the constant:

$$
\left.s_{i, j} \equiv\left(\frac{\gamma_{i}}{M_{i}}\right)\left(\frac{\gamma_{j}}{M_{j}}\right) E\left(x_{i} x_{j}\right)-E\left(x_{i}\right) E\left(x_{j}\right)\right]=\left(\frac{\gamma_{i}}{M_{i}}\right)\left(\frac{\gamma_{j}}{M_{j}}\right) e_{i, j}
$$

and

$$
s_{i, j}=\left\lceil\left(\frac{\gamma_{i}}{M_{i}}\right)\left(r_{m}\right)_{i} \bar{x}_{i}\right]\left\lceil\left(\frac{\gamma_{j}}{M_{j}}\right)\left(r_{m}\right)_{j} \bar{x}_{j}\right\rceil \rho_{i, j}
$$

This then provides the information necessary to compute the covariance matrix necessary for SME acceptability determination, $\mathbf{S}_{\mathrm{m}}$, from available historic covariance information. To complete the required information, Tables B1 through B3 are provided. Table B1 provides the elemental correlation matrix derived from historical data. Table B2 provides the average of the historical compositions used to develop this correlation matrix and Table B3 provides the relative standard deviations of the indicate component for these data.

Note that, for the sake of completeness, there are entries in Tables B1 through B3 for all of the components listed in Table A3. The entries in these tables are zero for the components that are not part of the PCCS calculations and for those components for which no historical data were available. 
Table B1. Elemental Correlation Matrix, $\underline{\mathbf{C}_{\mathbf{m}}}$

\begin{tabular}{|c|c|c|c|c|c|c|c|c|c|c|c|c|c|c|c|c|c|c|c|c|c|c|c|c|c|c|c|c|c|c|c|c|c|}
\hline & $\mathrm{Al}_{2} \mathrm{O}_{3}$ & $\mathrm{~B}_{2} \mathrm{O}_{3}$ & $\mathrm{BaO}$ & $\mathrm{HCOO}$ & $\mathrm{CaO}$ & $\mathrm{Ce}_{2} \mathrm{O}_{3}$ & $\mathrm{NaCl}$ & $\mathrm{Cr}_{2} \mathrm{O}_{3}$ & $\mathrm{Cs}_{2} \mathrm{O}$ & $\mathrm{CuO}$ & $\mathrm{NaF}$ & $\mathrm{Fe}_{2} \mathrm{O}_{3}$ & $\mathrm{~K}_{2} \mathrm{O}$ & $\mathrm{La}_{2} \mathrm{O}_{3}$ & $\mathrm{Li}_{2} \mathrm{O}$ & $\mathrm{MgO}$ & $\mathrm{MnO}$ & $\mathrm{MoO}_{3}$ & $\mathrm{NO}_{2}$ & $\mathrm{NO}_{3}$ & $\mathrm{Na}_{2} \mathrm{O}$ & $\mathrm{Na}_{2} \mathrm{SO}_{4}$ & $\mathrm{Nd}_{2} \mathrm{O}_{3}$ & $\mathrm{NiO}$ & $\mathrm{P}_{2} \mathrm{O}_{5}$ & $\mathrm{PbO}$ & $\mathrm{SiO}_{2}$ & $\mathrm{ThO}_{2}$ & $\mathrm{TiO}_{2}$ & $\mathrm{U}_{3} \mathrm{O}_{8}$ & $\mathrm{Y}_{2} \mathrm{O}_{3}$ & $\mathrm{ZnO}$ & $\mathrm{ZrO}_{2}$ \\
\hline $\mathrm{Al}_{2} \mathrm{O}_{3}$ & $\begin{array}{c}1 \\
-0233\end{array}$ & $\begin{array}{c}-0.2133 \\
-1\end{array}$ & 0 & 0 & 0.89978 & 0 & 0 & $\begin{array}{l}-0.1343 \\
-0.134\end{array}$ & 0 & 0.6744 & 0 & 0.9335 & $\begin{array}{l}0.7667 \\
0.0697\end{array}$ & 0 & $\begin{array}{l}0.7009 \\
0.1114\end{array}$ & $\begin{array}{l}0.8319 \\
0.0865\end{array}$ & 0.9221 & $\begin{array}{l}0 \\
0\end{array}$ & 0 & 0 & 0.9128 & $\begin{array}{l}0 \\
0\end{array}$ & 0 & $\begin{array}{c}0.2892 \\
-0.03906\end{array}$ & 0 & $\begin{array}{l}0 \\
0\end{array}$ & $\begin{array}{l}0.6898 \\
0.2228\end{array}$ & 0 & $\begin{array}{c}0.8816 \\
0.0056\end{array}$ & 0 & 0 & 0 & 0.2669 \\
\hline $\begin{array}{l}\mathrm{B}_{2} \mathrm{O}_{3} \\
\mathrm{arO}\end{array}$ & 0 & 0 & 0 & 0 & 0 & 0 & 0 & 0 & 0 & $\begin{array}{c}-0.148 \\
0\end{array}$ & 0 & $\begin{array}{c}-0.301 \\
0\end{array}$ & $\begin{array}{c}0.0971 \\
0\end{array}$ & 0 & $\begin{array}{c}0.1114 \\
0\end{array}$ & $\begin{array}{c}-0.003 \\
0\end{array}$ & $\begin{array}{c}-0.200 \\
0\end{array}$ & 0 & 0 & 0 & 0 & 0 & 0 & 0 & 0 & 0 & 0 & 0 & 0 & 0 & 0 & 0 & $\begin{array}{c}-0.190 \\
0\end{array}$ \\
\hline $\mathrm{HCOO}$ & 0 & 0 & 0 & 0 & 0 & 0 & 0 & 0 & 0 & 0 & 0 & 0 & 0 & 0 & 0 & 0 & 0 & 0 & 0 & 0 & 0 & 0 & 0 & 0 & 0 & 0 & 0 & 0 & 0 & 0 & 0 & 0 & 0 \\
\hline $\mathrm{CaO}$ & 0.8997 & -0.1928 & 0 & 0 & 1 & 0 & 0 & -0.01 & 0 & 0.6031 & 0 & 0.7989 & 0.6906 & 0 & 0.6231 & 0.8488 & 0.7535 & 0 & 0 & 0 & 0.7587 & 0 & 0 & 0.3564 & 0 & 0 & 0.6003 & 0 & 0.7085 & 0 & 0 & 0 & 0.3104 \\
\hline $\mathrm{Ce}_{2} \mathrm{O}_{3}$ & 0 & 0 & 0 & 0 & 0 & 0 & 0 & 0 & 0 & 0 & 0 & 0 & 0 & 0 & 0 & 0 & 0 & 0 & 0 & 0 & 0 & 0 & 0 & 0 & 0 & 0 & 0 & 0 & 0 & 0 & 0 & 0 & 0 \\
\hline $\mathrm{NaCl}$ & 0 & 0 & 0 & 0 & 0 & 0 & 0 & 0 & 0 & 0 & 0 & 0 & 0 & 0 & 0 & 0 & 0 & 0 & 0 & 0 & 0 & 0 & 0 & 0 & 0 & 0 & 0 & 0 & 0 & 0 & 0 & 0 & 0 \\
\hline $\mathrm{Cr}_{2} \mathrm{O}_{3}$ & -0.1343 & -0.2248 & 0 & 0 & -0.01 & 0 & 0 & 1 & 0 & -0.2473 & 0 & -0.0194 & -0.2603 & 0 & -0.0721 & 0.0055 & -0.2658 & 0 & 0 & 0 & -0.2752 & 0 & 0 & 0.786 & 0 & 0 & -0.162 & 0 & -0.059 & 0 & 0 & 0 & 0.536 \\
\hline $\mathrm{Cs}_{2} \mathrm{O}$ & 0 & 0 & 0 & 0 & 0 & 0 & 0 & 0 & 0 & 0 & 0 & 0 & 0 & 0 & 0 & 0 & 0 & 0 & 0 & 0 & 0 & 0 & 0 & 0 & 0 & 0 & 0 & 0 & 0 & 0 & 0 & 0 & 0 \\
\hline $\mathrm{CuO}$ & 0.6744 & -0.148 & 0 & 0 & 0.6031 & 0 & 0 & -0.2473 & 0 & 1 & 0 & 0.7322 & 0.6297 & 0 & 0.6401 & 0.6983 & 0.7662 & 0 & 0 & 0 & 0.6998 & 0 & 0 & 0.134 & 0 & 0 & 0.6446 & 0 & 0.638 & 0 & 0 & 0 & 0.1245 \\
\hline $\mathrm{NaF}$ & 0 & 0 & 0 & 0 & 0 & 0 & 0 & 0 & 0 & 0 & 0 & 0 & 0 & 0 & 0 & 0 & 0 & 0 & 0 & 0 & 0 & 0 & 0 & 0 & 0 & 0 & 0 & 0 & 0 & 0 & 0 & 0 & 0 \\
\hline $\mathrm{Fe}_{2} \mathrm{O}_{3}$ & 0.9335 & -0.301 & 0 & 0 & 0.7989 & 0 & 0 & -0.0194 & 0 & 0.7322 & 0 & 1 & 0.6866 & 0 & 0.7226 & 0.8255 & 0.9613 & 0 & 0 & 0 & 0.8852 & 0 & 0 & 0.4147 & 0 & 0 & 0.6753 & 0 & 0.9065 & 0 & 0 & 0 & 0.3327 \\
\hline $\mathrm{K}_{2} \mathrm{O}$ & 0.7647 & 0.0697 & 0 & 0 & 0.6906 & 0 & 0 & -0.2603 & 0 & 0.6297 & 0 & 0.6866 & 1 & 0 & 0.6065 & 0.6529 & 0.7055 & 0 & 0 & 0 & 0.8244 & 0 & 0 & 0.074 & 0 & 0 & 0.6369 & 0 & 0.7135 & 0 & 0 & 0 & 0.0119 \\
\hline $\begin{array}{l}\mathrm{I}_{2} \mathrm{O} \\
\mathrm{La}_{2}\end{array}$ & $\begin{array}{c}0 \\
0\end{array}$ & 0 & 0 & 0 & 0 & 0 & 0 & $\begin{array}{c}-0.205 \\
0\end{array}$ & 0 & 0 & 0 & 0 & 0 & 0 & 0 & $\begin{array}{c}0.903 \\
0\end{array}$ & $\begin{array}{c}0.753 \\
0\end{array}$ & 0 & 0 & 0 & $\begin{array}{c}.02+7 \\
0\end{array}$ & 0 & 0 & 0 & 0 & 0 & 0 & 0 & $\begin{array}{c}0.13 \mathrm{~J} \\
0\end{array}$ & 0 & 0 & 0 & $\begin{array}{c}0.0119 \\
0\end{array}$ \\
\hline $\mathrm{Li}_{2} \mathrm{O}$ & 0.7009 & 0.114 & 0 & 0 & 0.6231 & 0 & 0 & -0.0721 & 0 & 0.6401 & 0 & 0.7226 & 0.6065 & 0 & 1 & 0.9 & 0.6678 & 0 & 0 & 0 & 0.8337 & & 0 & 0.3613 & 0 & 0 & 0.9668 & 0 & 0.809 & 0 & 0 & 0 & 0.3577 \\
\hline $\begin{array}{l}\mathrm{LgO}_{2} \mathrm{O} \\
\mathrm{MgO}\end{array}$ & 0.8319 & $\begin{array}{c}0.114 \\
-0.0865\end{array}$ & 0 & 0 & 0.8488 & 0 & 0 & 0.0055 & 0 & $\begin{array}{l}0.06983 \\
0.698\end{array}$ & 0 & 0.8255 & $\begin{array}{l}0.00529 \\
0.6529\end{array}$ & 0 & $\begin{array}{l}1 \\
0.9\end{array}$ & 1 & 0.7514 & 0 & 0 & 0 & 0.8438 & 0 & 0 & 0.4495 & 0 & 0 & $\begin{array}{l}0.8760 \\
0.8762\end{array}$ & 0 & $\begin{array}{l}0.00873 \\
\end{array}$ & 0 & 0 & 0 & 0.3648 \\
\hline $\mathrm{MnO}$ & 0.9221 & -0.268 & 0 & 0 & 0.7535 & 0 & & -0.2658 & 0 & 0.7662 & 0 & 0.9613 & 0.7055 & 0 & 0.6678 & 0.7514 & 1 & & 0 & 0 & 0.8937 & & 0 & 0.1944 & 0 & & 0.6432 & 0 & 0.8734 & 0 & & & 0.1809 \\
\hline $\mathrm{MoO}_{3}$ & 0 & 0 & 0 & 0 & 0 & 0 & & 0 & 0 & 0 & & 0 & 0 & & 0 & 0 & 0 & & & & 0 & & & 0 & & & 0 & & 0 & & & & 0 \\
\hline $\mathrm{NO}_{2}$ & 0 & 0 & 0 & 0 & 0 & c & & 0 & 0 & 0 & & & 0 & & 0 & & & & & & & & & & & & & & & & & & \\
\hline NC & 0 & 0 & 0 & 0 & 0 & c & & 0 & 0 & 0 & & & 0 & & & 0 & & & & & & & & 0 & 0 & 0 & 0 & 0 & 0 & 0 & 0 & 0 & 0 \\
\hline $\mathrm{Na}_{2} \mathrm{O}$ & 0.9128 & 0.0106 & 0 & 0 & 0.7587 & ( & & -0.2752 & 0 & 0.6998 & 0 & 0.8852 & 0.8244 & & 0.8337 & 0.8438 & 0.8937 & 0 & & & & & & 0.1507 & 0 & 0 & 0.8456 & 0 & 0.8905 & 0 & & & 0.1403 \\
\hline $\mathrm{Na}_{2} \mathrm{SO}_{4}$ & 0 & 0 & 0 & 0 & 0 & c & & 0 & 0 & 0 & & 0 & 0 & & 0 & 0 & 0 & & & & & & & 0 & & & 0 & & 0 & & & & 0 \\
\hline $\mathrm{Nd}_{2} \mathrm{O}_{3}$ & 0 & 0 & 0 & 0 & 0 & c & & 0 & 0 & 0 & ( & 0 & 0 & & 0 & 0 & 0 & & & & & & & & & & 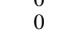 & & & & & & \\
\hline $\mathrm{NiO}$ & 0.2892 & -0.3906 & 0 & 0 & 0.3564 & 0 & 0 & 0.786 & 0 & 0.134 & 0 & 0.4147 & 0.074 & & 0.3613 & 0.4495 & 0.1944 & 0 & & & 0.1507 & & & & & & 0.25 & & 0.3343 & 0 & & & 0.713 \\
\hline $\mathrm{P}_{2} \mathrm{O}_{5}$ & 0 & 0 & 0 & 0 & 0 & 0 & 0 & 0 & 0 & 0 & 0 & 0 & 0 & 0 & 0 & 0 & 0 & 0 & ( & & & & & & & & & & 0 & & & & \\
\hline $\mathrm{PbO}$ & 0 & 0 & 0 & 0 & 0 & 0 & 0 & 0 & 0 & 0 & 0 & 0 & 0 & 0 & 0 & c & 0 & 0 & ( & & & & & & & & & & & & & & \\
\hline $\mathrm{SiO}_{2}$ & 0.6898 & 0.2229 & 0 & 0 & 0.6003 & 0 & 0 & -0.1 & 0 & 0.6446 & 0 & 0.6753 & 0.6369 & 0 & 0.9668 & 0.8762 & 0.6432 & 0 & 0 & c & 0.8456 & & ( & 0.25 & 0 & 0 & 1 & 0 & 0.7449 & 0 & 0 & 0 & 0.2598 \\
\hline $\mathrm{ThO}_{2}$ & 0 & 0 & 0 & 0 & c & 0 & 0 & & 0 & 0 & 0 & 0 & 0 & 0 & 0 & 0 & 0 & 0 & 0 & & & & 0 & & 0 & 0 & 0 & 0 & 0 & 0 & 0 & 0 & 0 \\
\hline $\mathrm{Ti}$ & 0.8816 & -0.0561 & 0 & 0 & 0.7085 & 0 & 0 & -0.059 & 0 & 0.638 & 0 & 0.9165 & 0.7135 & 0 & 0.809 & 0.7873 & 0.8734 & 0 & c & ( & 0.8905 & & 0 & 0.3343 & 0 & 0 & 0.7449 & 0 & 1 & 0 & 0 & 0 & 0.3595 \\
\hline $\mathrm{U}_{3} \mathrm{O}_{8}$ & 0 & 0 & 0 & 0 & 0 & 0 & 0 & 0 & 0 & 0 & 0 & 0 & 0 & 0 & 0 & 0 & 0 & 0 & ( & & & & ( & 0 & 0 & 0 & 0 & 0 & 0 & 0 & 0 & 0 & 0 \\
\hline $\mathrm{Y}_{2} \mathrm{C}$ & 0 & 0 & 0 & 0 & c & c & 0 & 0 & 0 & c & 0 & 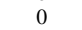 & 0 & 0 & 0 & 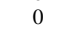 & 0 & 0 & 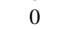 & & & & ( & 0 & & 0 & 0 & 0 & 0 & 0 & 0 & 0 & 0 \\
\hline $\mathrm{ZnO}$ & 0 & 0 & 0 & 0 & 0 & 0 & 0 & 0 & 0 & 0 & 0 & 0 & 0 & 0 & 0 & 0 & 0 & 0 & 0 & & & 0 & 0 & 0 & 0 & 0 & 0 & 0 & 0 & 0 & 0 & 0 & 0 \\
\hline $\mathrm{ZrO}_{2}$ & 0.2669 & -0.1907 & 0 & 0 & 0.3104 & 0 & 0 & 0.536 & 0 & 0.1245 & 0 & 0.3327 & 0.0119 & 0 & 0.3577 & 0.3648 & 0.1809 & 0 & 0 & 0 & 0.1403 & 0 & 0 & 0.713 & 0 & 0 & 0.2598 & 0 & 0.3595 & 0 & 0 & 0 & 1 \\
\hline
\end{tabular}

Table B2. Historical Average Composition

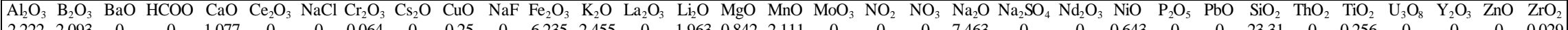

Table B3. Relative Standard Deviation

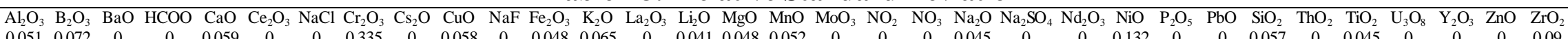

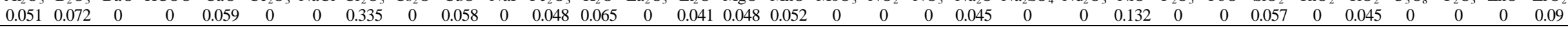


In PCCS implementations before revision 3 of this report, only the historic covariance matrix was employed. However, since compositions during operation may differ significantly from the historical mean composition used to define $\mathbf{S}_{\mathrm{m}}$, the variance estimates using the historic covariance matrix may not adequately describe the measured molar oxide concentrations in $\underline{\mathrm{z}}$.

Therefore to better represent the true composition and covariances for the current SME batch, starting with revision 3 , the averaged measured elemental composition, $\underline{x}_{n}$, was used to estimate a covariance matrix based upon these n sample measurements, $\mathbf{S}_{\mathrm{n}}$. This is accomplished by substituting the $\mathrm{i}^{\text {th }}$ member of the measured elemental composition, $\left(\underline{\mathrm{x}}_{\mathrm{n}}\right)_{\mathrm{i}}$, for $\overline{\mathrm{x}}_{\mathrm{i}}$ in the above covariance matrix definition:

$$
\left(\mathbf{S}_{\mathrm{n}}\right)_{\mathrm{i}, \mathrm{j}}=\left\lceil\left(\frac{\gamma_{\mathrm{i}}}{\mathrm{M}_{\mathrm{i}}}\right)\left(\mathrm{r}_{\mathrm{m}}\right)_{\mathrm{i}}\left(\underline{\mathrm{x}}_{\mathrm{n}}\right)_{\mathrm{i}}\right]\left[\left(\frac{\gamma_{\mathrm{j}}}{\mathrm{M}_{\mathrm{j}}}\right)\left(\mathrm{r}_{\mathrm{m}}\right)_{\mathrm{j}}\left(\underline{\mathrm{x}}_{\mathrm{n}}\right)_{\mathrm{j}}\right\rceil \rho_{\mathrm{i}, \mathrm{j}}
$$

Since sufficient information does not exist to determine the exact nature of the analytical errors, both covariance matrices, i.e., $\mathbf{S}_{\mathrm{m}}$ and $\mathbf{S}_{\mathrm{n}}$, will be computed along with their impact on the corresponding property variances. The proper test is that based upon the larger resulting property variance.

The tests for measurement acceptability will be defined that use the covariance matrices just determined. If the average measurement $\underline{z}_{n}$ is distributed in probability as multivariate Gaussian around its true value $\underline{\mu}$ with covariance $\left(\frac{\boldsymbol{\Sigma}}{\mathrm{n}}\right)$, then a linear form $\left(\underline{\mathrm{z}}_{\mathrm{n}} \underline{\mathrm{a}}^{\mathrm{T}}\right)$ is distributed as univariate Gaussian [22] with mean $\left(\underline{\mu}^{\mathrm{a}}{ }^{\mathrm{T}}\right)$ and variance $\left(\frac{\underline{\mathrm{a}} \underline{\mathrm{a}}^{\mathrm{T}}}{\mathrm{n}}\right)$. One consequence of this is that the statistics [23]:

$$
\frac{\underline{\mathrm{z}}_{\mathrm{n}} \underline{\mathrm{a}}^{\mathrm{T}}-\underline{\underline{\mu}} \underline{\underline{\mathrm{a}}}^{\mathrm{T}}}{\sqrt{\frac{\underline{\mathrm{a}}_{\mathrm{m}} \underline{\underline{\mathrm{a}}}^{\mathrm{T}}}{\mathrm{n}}}} \quad \text { and } \quad \frac{\underline{\mathrm{z}}_{\mathrm{n}} \underline{\underline{\mathrm{a}}}^{\mathrm{T}}-\underline{\underline{\mu}} \underline{\mathrm{a}}^{\mathrm{T}}}{\sqrt{\frac{\underline{\mathrm{a}}_{\mathrm{n}} \underline{\mathrm{a}}^{\mathrm{T}}}{\mathrm{n}}}}
$$

are each distributed as a Student's $\mathrm{t}$ with $(\mathrm{m}-1)$ degrees of freedom, where $\mathrm{n}$ is the number of samples on which $\underline{Z}_{n}$ is determined, $\mathbf{S}_{\mathrm{m}}$ is the previous sample estimate of $\boldsymbol{\Sigma}$ based on $\mathrm{m}$ historic observations and their average, and $\mathbf{S}_{\mathrm{n}}$ is a sample estimate of $\boldsymbol{\Sigma}$ based upon the historic correlation information and the average of the current SME measurements.

Furthermore the number of historical analyses, m, necessary to define reasonable estimates of the pair-wise correlations increases as the number of individual elements 
increases. $^{\dagger}$ For the DWPF prototypic information, only 22 measured compositions are available to estimate the historic SME covariance matrix for the 15 elements of interest for Waste Qualification Runs and Radioactive startup. ${ }^{\dagger \dagger}$ This number of points appears small when compared to the desired number (i.e., approximately 45), but reasonable to estimate variances for individual elements.

The ramification of using such a relatively small sample size is that the correlations (but not the variances) may be poorly estimated. The correlations estimated from the 22 historic, prototypic SME measurements are provided in Table B3 of Appendix B. However, since most of the correlations are large and positive (e.g., $\rho_{\mathrm{Al}, \mathrm{Ca}}=0.90, \rho_{\mathrm{Al}, \mathrm{Fe}}=$ $0.93, \rho_{\mathrm{Al}, \mathrm{Si}}=0.69$, etc.), it would be difficult to imagine that the correlation estimates from a larger sample set would be appreciably larger than those in Table A5. ${ }^{\dagger}$ If the correlations are generally smaller, then the variance estimated would also generally be smaller and the current estimates would be conservative.

For a constraint (call it constraint $\mathrm{i}$ ) that may be expressed as a linear combination (through vector $\underline{a}_{i}$ ) of the average molar oxide concentrations (the $\underline{z}$ vector), the measurement error variance may be represented by $v\left[z_{n}\left(a_{i}\right)^{T}\right]$, where the appropriate variance will be the maximum of the variances associated with the historic covariance matrix and the covariance based upon the current sample measurement:

$$
\mathrm{V}\left[\mathbf{z}_{\mathrm{n}}\left(\mathrm{a}_{\mathrm{i}}\right)^{\mathrm{T}}\right] \equiv \max \text { imum }\left\{\begin{array}{l}
\frac{\left(\mathrm{a}_{\mathrm{i}}\right) \mathbf{S}_{\mathrm{m}}\left(\mathrm{a}_{\mathrm{i}}\right)^{\mathrm{T}}}{\mathrm{n}}=\frac{1}{\mathrm{n}} \sum_{\mathrm{j}=0 \mathrm{k}=0}^{\mathrm{q}-1 \mathrm{q}-1} \sum_{\mathrm{k}=0}\left(\mathrm{a}_{\mathrm{i}}\right)_{\mathrm{j}}\left(\mathrm{a}_{\mathrm{i}}\right)_{\mathrm{k}}\left(\mathbf{S}_{\mathrm{m}}\right)_{\mathrm{j}, \mathrm{k}} \\
\frac{\left(\mathrm{a}_{\mathrm{i}}\right) \mathbf{S}_{\mathrm{n}}\left(\mathrm{a}_{\mathrm{i}}\right)^{\mathrm{T}}}{\mathrm{n}}=\frac{1}{\mathrm{n}} \sum_{\mathrm{j}=0 \mathrm{k}=0}^{\mathrm{q}-1 \mathrm{q}-1} \sum_{\mathrm{k}=0}\left(\mathrm{a}_{\mathrm{i}}\right)_{\mathrm{j}}\left(\mathrm{a}_{\mathrm{i}}\right)_{\mathrm{k}}\left(\mathbf{S}_{\mathrm{n}}\right)_{\mathrm{j}, \mathrm{k}}
\end{array}\right]
$$

Thus, the measurement uncertainty for this $\mathrm{i}^{\text {th }}$ constraint, $\mathrm{MU}_{\mathrm{i}}$, may be computed using:

$$
\mathrm{MU}_{\mathrm{i}} \equiv \mathrm{t}_{\alpha}(\mathrm{m}-1) \sqrt{\mathrm{V}\left[\underline{\mathrm{z}}_{\mathrm{n}}\left(\underline{\mathrm{a}}_{\mathrm{i}}\right)^{\mathrm{T}}\right]}
$$

where, as previously stated, $\mathrm{t}_{\alpha}(\mathrm{m}-1)$ is the upper $100 \alpha \%$ tail of the Student's t distribution with $\mathrm{m}-1$ degrees of freedom. In this situation, $\mathrm{m}=22$, so the appropriate $\mathrm{t}$ statistic for a $95 \%$ confidence level is $\mathrm{t}_{0.05}(21)=1.721$. If, at management's discretion, the measurement uncertainty is to be accounted for at a lower confidence level for a non-

A reasonable rule-of-thumb is that at least three times the number of individual elements are necessary to estimate reasonable correlations. Likewise, 10 points are normally sufficient to reasonably estimate the variance (i.e., $\mathrm{s}_{\mathrm{i}, \mathrm{i}}$ ) for an individual parameter.

$\dagger$ A total of 24 measured compositions were originally available to estimate the covariance matrix; however, two were later omitted as outliers [24, 25].

$\dagger \quad$ At least, it is difficult to imagine that revised correlations would have a significant impact on the property variances computed from the resulting covariance matrices. 


\section{Revision 4}

waste-affecting constraint, it can be accomplished through this t statistic. Increasing $\alpha$ above 0.05 correspondingly reduces the confidence associated with the handling of the measurement uncertainty.

To complete the MAR assessment of the $i^{\text {th }}$ constraint, combine the offset, $B_{i}$, (appropriately adjusted for any applicable property model uncertainty) and the measurement uncertainty (developed above) into the constraint inequality as given by equation (1) in the body of this report to obtain:

$$
\underline{\mathrm{z}}_{\mathrm{n}}\left(\underline{\mathrm{a}}_{\mathrm{i}}\right)^{\mathrm{T}}-\beta_{\mathrm{i}}-\mathrm{MU}_{\mathrm{i}} \geq 0
$$

This inequality defines the MAR for $i^{\text {th }}$ constraint. The overall acceptability MAR is defined by the confluence of all of the MAR's representing the individual constraints. A SME composition must be proven interior to all such constraint regions to be adjudged acceptable. There is thus the concomitant possibility that the simultaneous application of many such tests might cause the false-reject rate to be too high, that is, if these tests are independent. However, only the constraints for $\mathrm{B}, \mathrm{Li}$, and $\mathrm{Na}$ PCT releases must be controlled to a high degree of certainty [2]; furthermore, these tests are in no way independent as they are all based upon $G_{p}$ [1]. Finally the results from DWPF Waste Qualification testing [1] and the DWPF's ongoing operations illustrate that the simultaneous application of all constraints for process and product control does not cause the false-reject rate to burgeon. Thus the measurement uncertainty outlined in this appendix can be applied as indicated; however, if problems concerning the false-reject rate are noticed in future DWPF operation, techniques are available to correctly account for the simultaneous application of constraints. 